\title{
GraSPING AT STRAWS: EXPLORING PDVSA'S ACCESS TO DEBTOR RELIEF UNDER RESTRUCTURING REGIMES ${ }^{1}$
}

\author{
Lucas Jullian
}

\begin{abstract}
Petróleos de Venezuela, S.A. (PDVSA), the state-owned oil company of the Bolivarian Republic of Venezuela, is undergoing significant financial distress. As evidenced by the heavily discounted prices of its publicly traded bonds, there is speculation concerning PDVSA's ability to service its debts. While public debate has focused on the probability and implications of a default, little has been written about PDVSA's possible use of debtor relief in order to restructure its liabilities. Thus, this paper seeks to explore the forms of debtor relief PDVSA may seek to avail itself of, and whether PDVSA may be eligible of such relief under the pertinent restructuring regimes. After assessing PDVSA's assets, operations, liabilities, and legal form, this paper explains that all strategies considered would be fraught with considerable legal and practical challenges. Even if not insurmountable, such obstacles could provoke highly contentious, litigious proceedings. The paper is meant to be accessible to readers who have neither specialized in international bankruptcy, nor in PDVSA's bonds or current circumstances. Therefore, specialists in either field may find this Paper overly descriptive or covering familiar ground.
\end{abstract}

1. This Paper was developed as an assignment for the seminar LAW 916: Adv. Issues in Priv. Fin. \& Corp. \& Sovereign Debt Restructuring (Fall 2016-Spring 2017) at the University of Pennsylvania Law School. The author, a member of the 2017 class of the MBA program at the Wharton School at the University of Pennsylvania, was enrolled as a non-law student. 
INTRODUCTION 865

I. WHAT IS PDVSA?

A. Legal Form \& Legal Relationship with the Venezuelan State

1. Constitution of the Bolivarian Republic of Venezuela

2. Organic Law of Hydrocarbons 874

3. PDVSA's Articles of Incorporation and Corporate Statutes .876

4. Legal Summary ................................................. 878

B. Assets ................................................................ 879

C. Liabilities................................................................. 886

D. Summary ................................................................ 889

II. RESTRUCTURING REGIME \& DEBTOR RELIEF ALTERNATIVES 890

A. Challenge \#1: Eligibility ........................................... 894

B. Challenge \#2: Avoiding Dismissal by U.S. Courts........ 899

C. Challenge \#3: A Practical Procedural Obstacle in Passing a Plan 902

III. VENEZUELAN FOREIGN MAIN PROCEEDING \& ANCILLARY CHAPTER 15 RECOGNITION ................................................ 904

A. Challenge \#1: Eligibility .......................................... 904

B. Challenge \#2: Avoiding Dismissal or Limited Relief from U.S. Courts 906

IV. OTHER ALTERNATIVES................................................... 913

A. Foreign Non-Main Proceeding \& Ancillary Chapter 15 Recognition 914

B. Venezuelan Foreign Main Proceeding \& Ancillary Chapter 15 Recognition, After Modifying PDVSA Legal Regime and Venezuelan Insolvency Regime 914

C. Amend Governing Law \& Jurisdiction of U.S. Liabilities 


\section{INTRODUCTION}

On November 2, 2017, President Nicolás Maduro of the Bolivarian Republic of Venezuela announced that Venezuela would seek to renegotiate its external debt - including that of its state-owned oil company, Petróleos de Venezuela, S.A. (PDVSA). ${ }^{2}$ For a statement with such crucial repercussions for Venezuela's and PDVSA's creditors, it was unfortunately anything but clear: President Maduro seemed to interchangeably use the terms "refinancing," "restructuring," and "reformatting" of debt, and confusingly added that Venezuela would nonetheless continue to "satisfy [its] international obligations."

The events that have transpired since President Maduro's statements have not provided clarification, and they are increasingly ominous in nature. While PDVSA maintains it has initiated the transfer of interest payments due since the President's announcement, ${ }^{4}$ a lack of evidence of payment has led S\&P to downgrade PDVSA to "selective default," while Moody's has downgraded PDVSA to "technical default." Although debt investors have so far refrained from initiating legal actions against PDVSA due to late payments, capital market participants seem to share Moody's expectations that PDVSA will continue to "miss or default on further payments": as of March 6, 2018, PDVSA's unsecured bonds were priced between 20.8 and 30.4 cents on the dollar. ${ }^{7}$ For those unfamiliar with bond pricing, such heavily discounted prices are reflective of a significantly distressed firm, which "generally implies, if not invariably results in, some type of ... restructuring ... or a sale of assets and subsequent liquidation."

2. Katia Porzecanski, Patricia Laya, Ben Bartenstein, and Christine Jenkins Tanzi, Venezuela Will Seek to Restructure Debt, Blaming Sanctions, Bloomberg, Nov. 2, 2017, https://www.bloomberg.com/news/articles/2017-11-02/venezuela-will-seek-to-restructuredebt-as-sanctions-take-hold.

3. Bret Rosen, Venezuela's Default: What is Maduro Thinking?, AMERICAS QUARTERLY, Nov. 5, 2017, http://www.americasquarterly.org/content/venezuelas-defaultwhat-maduro-thinking.

4. PDVSA (@PDVSA), TwITTER (Dec. 14, 2017, 8:18 PM), https://twitter.com/PDVSA/status/941477507072741376.

5. Ben Bartenstein, Venezuela Is Late on $\$ 1.7$ Billion and Bond Traders are Stuck, BLOOMBERG, Feb. 15, 2018, https://www.bloomberg.com/news/articles/2018-0215/venezuela-is-late-on-1-7-billion-and-bond-traders-are-stuck.

6. MoOdy's Investors Service, Issuer Comment, Government of Venezuela: EMTA ReCommendation Points to FuRTher Events of Missed Payments 1 '(Jan. 22, 2018).

7. See Appendix 2: PDVSA \& Venezuela Bond Pricing (illustrating in two graphs the bond pricing of PDVSA and Venezuela bond pricing from October, 6, 2015 to March 6, 2018).

8. Stephen G. Moyer, Distressed Debt Analysis: Strategies for Speculative INVESTORS 7 (2005). This is not to be taken as a rule, but rather as a general observation made 
The saga of PDVSA's potential inability - or unwillingness - to satisfy its financial obligations has fueled active debates amongst observers on the prospect and implications of such an event. This issue is often incorporated into the broader discussion involving PDVSA's sole shareholder-the Bolivarian Republic of Venezuela (Venezuela) - which finds itself under commensurate economic and financial duress. ${ }^{9}$ Their dire predicaments have raised questions such as: will PDVSA or Venezuela default? Should they default? If they were to default-whether by choice or circumstance- when would that occur? Given PDVSA's status as a stateowned enterprise (SOE), what would their defaults imply for their own and each other's creditors? In case of default, what could they do to protect themselves from creditors $?^{10}$

by Moyer on situations in which "all or some portion of unsecured debt [is] trading at a market discount of more than $40 \%$."

9. It is beyond the scope of this paper to discuss the current economic and financial situation of Venezuela. For the purposes of this point, it should suffice to note that Moody's has given Venezuela a C rating, worse than PDVSA's Ca rating (see Appendix 1: PDVSA \& Venezuela Long Term Rating History), and that Venezuela's unsecured bond prices also reflect distress and investors' significant doubts on their full repayment; (see Appendix 2: PDVSA \& Venezuela Bond Pricing). For a broader overview of Venezuela's current economic condition see Zeeshan Aleem, Venezuela's Economic Crisis Is So Dire That Most People Have Lost an Average of 19 Pounds, Vox (Feb. 22, 2017), http://www.vox.com/world/2017/2/22/14688194/venezuela-crisis-study-food-shortage;

William Finnegan, Letter From Venezuela: Venezuela, A Failing State, THE NEw YoRKER (Nov. 14, 2016), http://www.newyorker.com/magazine/2016/11/14/venezuela-a-failingstate; Rick Gladstone, How Venezuela Fell Into Crisis, and What Could Happen Next, N.Y. TiMES (May 27, 2016), https://www.nytimes.com/2016/05/28/world/americas/venezuelacrisis-what-next.html?_r=0; Rosamond Hutt, Venezuela's Economic Crisis: All You Need to Know in 4 Charts, World ECONOMIC Forum (June 15, 2016) https://www.weforum.org/agenda/2016/06/venezuela-economic-crisis-in-4-charts/; Ray Sanchez, Venezuela: How Paradise Got Lost, CNN (Apr. 21, 2017), http://www.cnn.com/2017/04/21/americas/venezuela-crisis-explained/; Jonathan Wheatley, Andres Schipani, and Robin Wigglesworth, Venezuela: A Nation in Bondage, FinANCIAL Times (Nov. 10,2016), https://www.ft.com/content/55ebfe26-a665-11e6-8b6902899e8bd9d1;';'; Venezuela: A Nation in a State, The Economist (Feb. 18, 2016), http://www.economist.com/blogs/graphicdetail/2016/02/graphics-political-and-economic-

guide-venezuela; Venezuela, THE ECONOMIST: INTELLIGENCE UNIT, http://country.eiu.com/venezuela\# (last visited Apr. 29, 2017); Venezuela: Overview, THE WORLD BANK, , http://www.worldbank.org/en/country/venezuela/overview\#1 (last visited Apr. 28, 2017) (examining Venezuela's current economic crisis and conditions).

10. Perhaps the most illustrative exchange debating these issues has been that between Venezuelan economists Ricardo Hausmann and Francisco Rodríguez. Mr. Hausmann is Director of Harvard's Center for International Development and Professor of the Practice of Economic Development at the Kennedy School of Government. Mr. Rodríguez is Chief Economist at Torino Capital, and previously Chief Andean Economist at Bank of America Merryl Lynch. Since 2014, these former co-editors and co-authors have held one of the most longstanding and most publicized debates on the issue of Venezuela's and PDVSA's potential defaults. See Venezuela Before Chavez: Anatomy of an Economic Collapse (Ricardo 
When a working version of this paper had been drafted (June 25, 2017) and made publicly available (July 24, 2017), there had been a notable absence of published discourse or research on PDVSA's possible restructuring options outside of default or highly contentious legal maneuvers. ${ }^{11}$ Since then, a number of articles and white papers have tackled

Hausman and Francisco Rodriguez eds., 2014); Ricardo Hausmann, Francisco Rodriguez, and Rodrigo Wagner, Growth Collapse, (Ctr. for Int'l Dev. at Harvard Univ., Working Paper No.136, (Oct. 2006), https://wcfia.harvard.edu/files/wcfia/files/hausmann_growth.pdf Andrew Rosati, These Harvard Economists Offer Differing Views for How to Save Venezuela, BLOOMBERG (Oct. 19, 2016), https://www.bloomberg.com/news/articles/2016-10-19/asvenezuelan-expats-see-end-a-harvard-wall-street-feud-emerges (demonstrating the collaboration of Hausmann and Rodriquez). In order to view the evolution of this exchange, see Ricardo Hausmann, It Could Be Too Late to Avoid Catastrophe in Venezuela, FinANCIAL Times, Feb. 3, 2016, https://www.ft.com/content/204fc996-c8d5-11e5-a8efea66e967dd44\#axzz3zA5qBhSc; Ricardo Hausmann and Miguel Angel Santos, Should Venezuela Default, Project Syndicate, (Sept. 5, 2014), https://www.projectsyndicate.org/commentary/ricardo-hausmann-and-miguel-angel-santos-pillory-the-madurogovernment-for-defaulting-on-30-million-citizens-but-not-on-wall-

street?barrier=accessreg; Ricardo Hausmann and Mark Walker, Restructuring Debt in the Dark, PROJECT SYNDICATE (Oct. 6, 2016), https://www.projectsyndicate.org/commentary/debt-restructuring-perils-for-venezuela-by-ricardo-hausmannand-mark-walker-2-2016-10; Francisco Rodríguez, Why Venezuela Should Not Default, FinANCIAL Times, Sept. 12, 2014, https://www.ft.com/content/6e350887-8b55-3150-9eb2b17ae10fa6b0;“"; Francisco Rodríguez, Venezuela Has Good Reasons to Avoid Default, BLOOMBERG, Aug. 11, 2016, https://www.bloomberg.com/view/articles/2016-0811/venezuela-has-good-reasons-to-avoid-default; Post-Chavez Venezuela: A Roadmap for Reconstruction, BROOKINGS (October 18, 2016), https://www.brookings.edu/events/postchavez-venezuela-a-roadmap-for-reconstruction Venezuelan Caucus at HKS, What does the future hold for Venezuela?, YouTuBE (March 20,2015), https://www.youtube.com/watch? $v=V z 9 s g 3 H B e O s$ (discussing the impact of bond default on Venezuela's economic condition).

For discussions on other issues raised by Venezuela's and PDVSA's predicaments, see PAOLO Colla, Anna Gelpern, and G. Mitu Gulati, The Puzzle of PDVSA Bond Prices, (Aug. 16, 2016) available at $\mathrm{https}: / / \mathrm{ssrn} . \mathrm{com} / \mathrm{abstract}=2816856$; Mark C. Weidemaier and Matthew Gauthier, Venezuela as a Case Study in Limited (Sovereign) Liability, CAP. MкT.S L. J. (Dec. 8, 2016) (forthcoming) available at https://ssrn.com/abstract=2882835; Mitu G. Gulati and Mark Weidemaier, Veil Piercing When a Sovereign Owns the Shares, CREDIT SLIPS (Feb. 6, 2017), http://www.creditslips.org/creditslips/2017/02/veil-piercing-when-a-sovereign-ownsthe-shares.html; Mitu G. Gulati and Mark Weidemaier, Stripping PDVSA's Assets, CREDIT SLIPS (Feb. 18, 2017), http://www.creditslips.org/creditslips/2017/02/stripping-pdvsasassets.html; Mitu G. Gulati and Mark Weidemaier, Marblegate and the Use of Exit Consents to Restructure (Venezuelan) Sovereign Debt, CREDIT SLIPS (Feb. 25, 2017), http://www.creditslips.org/creditslips/2017/02/marblegate-and-sovereign-restructuring.html ; and Mitu G. Gulati and Mark Weidemaier, Bankruptcy and Non-Bankruptcy Options for PDVSA, CREDIT SLIPS (Mar. 12, 2017), http://www.creditslips.org/creditslips/2017/03/bankruptcy-and-non-bankruptcy-options-forpdvsa.html (discussing the various limitations of a restructuring of PDVSA).

11. LuCAS Jullian, Grasping at Straws: ExPloring PDVSA's ACCESS to Debtor RELIEF UNDER RESTRUCTURING REgimes (June 25, 2017), available at https://papers.ssrn.com/sol3/papers.cfm?abstract_id=3005810. For example, certain articles 
the question of how PDVSA may be able to restructure its debts. ${ }^{12}$ However, there remains a dearth of exhaustive analyses of paths involving debtor relief

and essays have focused on highly contentious maneuvers, such as possible strategies Venezuela may pursue to strip PDVSA of its assets, or removing PDVSA's monopoly over the Venezuelan oil industry. See, e.g., Mitu G. Gulati and Mark Weidemaier, Strip, Swap, Restructure, CREDIT SLIPS $\quad$ (Feb. http://www.creditslips.org/creditslips/2018/02/strip-swap-restructure.html; Mitu G. Gulati and Mark Weidemaier, Stripping PDVSA's Assets, CREDIT SLIPS (Feb. 18, 2017), http://www.creditslips.org/creditslips/2017/02/stripping-pdvsas-assets.html; Ricardo Hausmann and Mark Walker, Restructuring Debt in the Dark, PROJECT SYNDICATE (Oct. 6, 2016), https://www.project-syndicate.org/commentary/debt-restructuring-perils-forvenezuela-by-ricardo-hausmann-and-mark-walker-2-2016-10 (suggesting various restructuring strategies).

Others have focused on issues of sovereign veil-piercing, in the event PDVSA or Venezuela default. See Mitu G. Gulati and Mark Weidemaier, Veil Piercing When a Sovereign Owns the Shares, CREDIT SLIPS (Feb. 6, 2017), http://www.creditslips.org/creditslips/2017/02/veilpiercing-when-a-sovereign-owns-the-shares.html (discussing two issues that would arise if PDVSA shareholders were held liable to PDVSA creditors). Since June 25, 2017, several other articles and white papers have addressed this issue. See Richard J. Cooper and Boaz S. Morag, Venezuela's Imminent Restructuring and the Role Alter Ego Claims May Play in this Chavismo Saga, (Nov. 9, 2017) available at https://papers.ssrn.com/sol3/papers.cfm?abstract_id=3068455; Mitu Gulati, Mr. Maduro Write an Exam Question on Veil Piercing, CREDIT SliPS (Nov. 23, 2017), http://www.creditslips.org/creditslips/2017/11/mr-maduro-writes-an-exam-qeuestion-onveil-piercing-for-us.html; Mark Weidemaier, Domination Isn't (Always) Fraud, CREDIT SLIPS (Nov. 24, 2017), http://www.creditslips.org/creditslips/2017/11/domination-isnt-alwaysfraud-venezuela-edition.html; Mark Weidemaier, (Updated) About that Mysterious Crystallex Settlement, CREDIT SLIPS (Dec. 15, 2017), http://www.creditslips.org/creditslips/2017/12/about-that-mysterious-crystallexsettlement.html; Mark Weidemaier, Venezuela is Like...PDVSA's Alter Ego, and Vice Versa?, CREDIT SLIPS (Aug. 17, 2017), http://www.creditslips.org/creditslips/2017/12/aboutthat-mysterious-crystallex-settlement.html) (discussing the challenges PDVSA creditors, especially Crystallex, would face in pursueing alter ego claims).

12. See Lee C. Buchheit and Mitu G. Gulati, How to Restructure Venezuelan Debt (¿Cómo restructurar la deuda venezolana?), Duke LAW School Public LAW \& LEGAL THEORY SERIES No. 2017-52 (July 21, https://papers.ssrn.com/sol3/papers.cfm?abstract_id=3006680; LEE C. BUCHHEIT AND MiTU G. Gulati, Deterring Holdout Creditors in a Restructuring of PDVSA Bonds And PROMISORY NOTES, (Oct. 25, 2017), available at https://papers.ssrn.com/sol3/papers.cfm?abstract_id=3058468; Alice Chong and Mark A. Walker, Restructuring Certain Debt of the Republic of Venezuela and PDVSA on the Same Terms, (Mar. 11, 2018), available at https://papers.ssrn.com/sol3/papers.cfm?abstract_id=3136176; Richard J. Cooper and Mark A. Walker, Venezuela's Restructuring: A Realistic Framework, (Sept. 19, 2017), available at https://papers.ssrn.com/sol3/papers.cfm?abstract_id=3039678; Adam Lerrick, Venezuela's Debt: Untying the PDVSA Knot, AMERICAN ENTERPRISE InSTITUTE (Oct. 30, 2917), http://www.aei.org/publication/venezuelas-debt-untying-the-petroleos-de-venezuela-knot/ (discussing the difficulties that would arise with holdout creditors in the restructuring of PDVSA). 
that PDVSA may be able to avail itself of under restructuring regimes. ${ }^{13}$ The issue is not that these options are altogether forgotten, but rather that erudite and experienced professionals and scholars seem to fundamentally disagree on whether PDVSA has access to any relief in the first place. ${ }^{14}$

When Ricardo Hausmann ${ }^{15}$ and Mark Walker ${ }^{16}$ published an article discussing how Venezuela and PDVSA may seek to restructure their debts, they believed that "PDVSA may ... be entitled to bankruptcy protection both in Venezuela and in the US. In this event, PDVSA could obtain a courtmandated standstill order with respect to legal action against it until a restructuring agreement is reached, thereby avoiding a disorderly seizure of assets." 17

13. In this paper, the term "debtor relief" refers to the legal tools available under restructuring regimes aimed at aiding debtors in reaching restructuring agreements with its creditors, and/or protecting the debtor against creditors' attempts of collecting on their claims. These tools may include a stay on creditors' ability to collect on their claims or initiate litigation to that end, "cramdown" provisions to bind and enforce agreements on dissenting creditors, or the cancellation of certain contracts. In this paper, the term "restructuring regime" refers to any legal insolvency or restructuring regime or system that may provide tools for relief to debtors seeking to restructure their liabilities. The exception is the paper written by Richard Cooper and Mark Walker on September 19, 2017, which explores how restructuring regimes may be used to restructure PDVSA (see Richard J. Cooper and Mark A. Walker, Venezuela's Restructuring: A Realistic Framework (Sept. 19, 2017), available at https://papers.ssrn.com/sol3/papers.cfm?abstract_id=3039678 (discussing the challenges of restructuring PDVSA)).

14. See Pedro Jiménez and Amanda Parra Cristie, Restructuring on the Rise for Venezuelan Companies, Global Restructuring Review (Apr. 11, 2016), http://www.jonesday.com/files/Publication/4adc217c-8e7b-4dbe-afbc-

65e34990b25f/Presentation/PublicationAttachment/9fec 159b-0b27-4395-b24e-

6a4b9e633ec5/11-4-16_Restructuring_on_the_rise_for_Venezuelan_companies.pdf

(discussing the inadequacy of bankruptcy law in Venezuela to address the anticipated default of PDVSA on U.S. bonds). On April 11, 2016, Pedro Jimenez and Amanda Parra Cristie of Jones Day wrote an article on the different restructuring alternatives that PDVSA and other "similarly situated Venezuelan companies" may need to consider. The article discusses the use of Venezuela's insolvency laws, voluntary exchanges, and the use of Chapter 15 or Chapter 11 proceedings in the United States.

15. Ricardo Hausmann is Director of Harvard's Center for International Development and Professor of the Practice of Economic Development at the Kennedy School of Government. Previously, he has served as Chief Economist of the Inter-American Development Bank, as Minister of Planning of Venezuela, and as a member of the Board of the Central Bank of Venezuela.

16. Mark Walker is a Managing Director and Head of Sovereign Advisory at Millstein \& Co. Previously, he was Head of Sovereign Advisory at Rothschild, a senior advisor at Lazard, and Managing Partner of Cleary Gottlieb Steen \& Hamilton. At Cleary, Mark was a leader and co-founder of the firm's sovereign practice and developed much of the documentation that set the standard for sovereign debt restructurings during the 1980s and 1990s.

17. Ricardo Hausmann and Mark Walker, Restructuring Debt in the Dark, ProJeCT SYNDICATE (Oct. 6, 2016), https://www.project-syndicate.org/commentary/debt- 
When Mr. Walker coauthored a more detailed article on the subject (alongside his colleague Jill Dauchy), ${ }^{18}$ he noted that despite "the many issues relating to PDVSA's eligibility to seek bankruptcy protection ... we believe that under the circumstances envisaged there is a good chance that Venezuela could find a way to avail itself of this powerful tool."19 This, however, is not a universally held view. Charles-Antoine Wauters ${ }^{20}$ and Patrick Esteruelas ${ }^{21}$ of EMSO Asset Management ${ }^{22}$ have written that "there is no realistic chance of a U.S. bankruptcy proceeding offering a stay that protects assets located in the U.S. whether through a main proceeding (Chap. 11) or recognition of a foreign one (Chap. 15)., ${ }^{23}$ Additionally, Professors Mitu Gulati ${ }^{24}$ and Mark Weidemaier ${ }^{25}$ have held that:

[I]n order to be worth anything, a Venezuelan bankruptcy proceeding would need to be recognized in the United States .... It isn't clear that a Venezuela proceeding would merit such recognition. Nor is it clear that PDVSA meets eligibility requirements under US bankruptcy law. Still, bankruptcy offers the only mechanism for imposing restructuring terms on dissenting creditors, and that is what PDVSA most needs. ${ }^{26}$

Unfortunately for those concerned with this subject matter, these authors have not presented the analyses behind their diverging conclusions. ${ }^{27}$

restructuring-perils-for-venezuela-by-ricardo-hausmann-and-mark-walker-2-2016-10.

18. Jill Dauchy is a Managing Director at Millstein \& Co.

19. Mark Walker and Jill Dauchy, Restructuring Venezuelan Debt, THE CLS BLUE SKY BLOG (November 14, 2016), http://clsbluesky.law.columbia.edu/2016/11/14/restructuringvenezuelan-debt/. Since the working draft of this paper, Mark Walker has provided further delineations.

20. Charles-Antoine Wauters is portfolio counsel and research analyst at EMSO Asset Management.

21. Patrick Esteruelas is the senior analyst, sovereign credit at EMSO Asset Management.

22. EMSO Asset Management is an asset manager focused on sovereign, quasisovereign, and corporate fixed income opportunities within emerging markets.

23. Charles-Antione Wauters and Patrick Esteruelas, Emerging Market Sovereigns' Frequent Indulgence for their Quasi-Sovereigns, The EMERGING MKt.s RESTRUCTURING J. 23, 23-26 (Fall 2016), https://www.clearygottlieb.com/ /media/cgsh/files/emerging-marketsrestructuring-journal/emrj-issue-2-fall-2016/04-emerging-market-sovereigns-frequentindulgence-for-their-quasisovereigns.pdf.

24. Mitu Gulati is Professor of Law at the Duke University School of Law.

25. W. Mark C. Weidemaier is an Associate Professor of Law at the University of North Carolina at Chapel Hill.

26. Gulati and Weidemaier, Bankruptcy and Non-Bankruptcy Options for PDVSA,

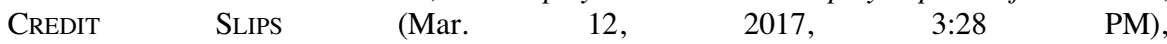
http://www.creditslips.org/creditslips/2017/03/bankruptcy-and-non-bankruptcy-options-forpdvsa.html.

27. As noted previously, since the distribution of a working draft of this Paper, Richard Cooper and Mark Walker are the exception, as they have provided their analysis on the 
It is this omission that motivates the development of this research. This paper seeks to explore the different forms of debtor relief PDVSA may wish or may be able to utilize, and subsequently seeks to highlight critical issues that may threaten access to such relief under the corresponding restructuring regimes.

The paper focuses narrowly on the challenges related to the statutes conforming the restructuring alternatives considered herein and does not evaluate other issues of perhaps equal importance arising from other origins - such as those of political nature. In particular, the paper does not contemplate specific challenges posed by the public policy positions and instruments of domestic or foreign public bodies that may be in force at any given point in time. These challenges, such as the declarations of the Venezuelan National Assembly ${ }^{28}$ or the sanctions imposed by the U.S. Executive Branch, ${ }^{29}$ would play undeniably paramount roles in shaping a

potential use of restructuring regimes.

28. For example, certain members of Venezuela's National Assembly (Venezuela's unicameral legislature) have reiterated that public debt cannot be issued without the National Assembly's consent and that any public debt issued without their consent will be null and void (see Annabella Abadi M., Corruption and Phantom Bonds, CARACAS Chronicles (June 9, 2017), https://www.caracaschronicles.com/2017/06/09/corruption-and-phantom-bonds/ (discussing the legality and morality of public debt bonds issued by Venezuela)). Any new public debt issued as part of a restructuring, and not condoned by National Assembly, would be subjected to this risk. However, there is debate as to whether debt issued by PDVSA requires the National Assembly's approval (see Claudio Rodríguez, An Inconvenient Fact": Not all Debt Requires National Assembly Approval, CARACAS Chronicles (May 8, 2017), https://www.caracaschronicles.com/2017/05/08/inconvenient-fact-not-debt-requiresnational-assembly-approval/ (discussing the entities that are not required to get approval from the National Assembly in issuing debt), and as to whether other public bodies may be able to validate new public debt (such as the Venezuelan Supreme Court, the Venezuelan Executive, or the Constituent Assembly) (see Buchheit and Gulati, Enforcing New Venezuelan Public Debt Instruments, FinANCIAL Times (Aug. 18, 2017), https://ftalphaville.ft.com/2017/08/18/2192462/enforcing-new-venezuelan-public-debtinstruments-maduro-bonds-part-2/ (discussing the differences in the U.S. Executive and Judicial branches recognizing Venezuela's debt instruments)). This Paper does not address or seek to resolve how these challenges may affect a potential restructuring of PDVSA.

29. Following the drafting of the working version of this Paper (June 25, 2017), on August 24, 2017, the U.S. Executive Branch implemented sanctions prohibiting U.S. persons from participating in "transactions related to, provision of financing for, and other dealings" of new debt or new equity of PDVSA or the Government of Venezuela (Exec. Order. No. 13808, 82 Fed. Reg. $41155 \S 1$ (August 29, 2017)). In the Interpretive Guidance provided by the Office of Assets Control (OFAC) of the U.S. Treasury, the concept of "new debt" not only encompasses debt issued following the implementation of Executive Order 13808, but also amendments to the terms of existing debt (see U.S. Department of the Treasury, OFAC FAQs, Questions 511, 535, https://www.treasury.gov/resourcecenter/faqs/Sanctions/Pages/faq_other.aspx\#venezuela (discussing how OFAC defines debt and equity and how U.S. financial institutions can complete transactions in compliance with U.S. sanctions against Venezuela)).

Thus, assuming that an essential component of a restructuring is the issuance of new securities 
potential restructuring of PDVSA's liabilities, but they lie beyond the scope of this Paper.

As a note on structure, the paper is organized into three sections. The first section provides an exploration of PDVSA's legal form, assets, and liabilities, so as to determine the kind of relief PDVSA may seek and be eligible for. The second section explores the regimes PDVSA may consider seeking relief in, and highlight obstacles that may impede access to such relief. This section will primarily evaluate (1) a U.S. domestic proceeding under Chapter 11 of the U.S. Bankruptcy Code, and (2) a Venezuelan foreign main proceeding, with recognition in the United States via a Chapter 15 petition. To round out the exercise, other alternatives will be discussed, regardless of their theoretical or seemingly impractical nature. Finally, the paper concludes on a wary note regarding the legal or practical viability of any restructuring option that depends on debtor relief and highlights the importance of being prepared for voluntary agreements or an outright default.

\section{WHAT IS PDVSA?}

In order to evaluate which kind of insolvency relief PDVSA may seek to utilize and whether it is eligible for such relief, it is instrumental to first understand just what, exactly, is PDVSA. Addressing this question requires analyses on the following three fronts:

LEGAL: What is PDVSA's legal form and relationship with the Venezuelan State?

ASSETS \& OPERATIONS: Under what jurisdictions are PDVSA's assets and operations?

LIABILITIES: What is the structure and nature of PDVSA's financial debt?

The first point - PDVSA's legal status and relationship with the State - is consequential on the matter of PDVSA's eligibility for relief. The second and third points, while also relevant on the matter of eligibility, are intimately related to understanding the jurisdictions under which PDVSA may seek relief. Ostensibly, PDVSA would seek to protect its operations and assets from potential actions undertaken by creditors. This involves understanding where those assets and operations are located, and where

and/or the amendment of existing debt, the current U.S. sanctions effectively bar any meaningful restructuring involving U.S. parties (e.g. investors, advisors, and other U.S. persons) from taking place. It is beyond the scope of this paper to speculate how or when such sanctions may be modified, the scope and duration of licenses possibly extended by OFAC in the case of a restructuring, or how PDVSA or Venezuela may seek to circumvent such sanctions in the implementation of a restructuring. 
creditors may seek to initiate and pursue actions against PDVSA.

\section{A. Legal Form \& Legal Relationship with the Venezuelan State}

From a legal point of view, PDVSA is a Sociedad Anónima ("stock corporation") organized under Venezuelan law, whose shares are wholly owned by the Venezuelan State. ${ }^{30}$ PDVSA was founded as part of the Venezuelan government's program for nationalizing the country's oil industry: on August 30, 1975, PDVSA was incorporated by Presidential Decree $\mathrm{N}^{\mathrm{o}} 1123,{ }^{31}$ to "coordinate, monitor and control all operations relating to hydrocarbons." 32 "This means that, exempting certain investments carried out in the 1990s as part of the apertura petrolera ("oil opening"), ${ }^{33}$ PDVSA has been the ultimate owner and holding company of all oil operations in Venezuela since 1976, when nationalization went into effect. ${ }^{34}$

As a Venezuelan commercial entity owned by the State and participating in the hydrocarbons sector, PDVSA is subject to a legal regime conformed by numerous laws, regulations, decrees, and norms set by the Venezuelan government. ${ }^{35}$ However, there are three legal instruments whose contents are critical for understanding the legal relationship between Venezuela and PDVSA. These are, by legal hierarchy, the following:

the Constitution of the Bolivarian Republic of Venezuela, the Organic Law of Hydrocarbons, and

Decree N 2.184: PDVSA's Articles of Incorporation and Corporate Statutes.

30. Petróleos de Venezuela, S.A., Offering Circular Petróleos de Venezuela, S.A., OFFERS TO EXCHANGE, 3 (September 16, 2016) https://www.scribd.com/document/324333858/PDVSA-2017-into-2020-Exchange-OfferOC-16-September-2016 (Accessed May 2, 2017).

31. Ministerio del Poder Popular de Petroleo y Minería, Efemérides PETROMINERAS, 2, http://www.pdvsa.com/images/siembra/pdf/sp1.pdf.

32. Petróleos de Venezuela, S.A., supra note 30 , at 3.

33. Alberto F. Ravell, A Brief Overview of Venezuela's Oil Policies, Lex Petrola, 9 (2011), https://s3.amazonaws.com/documents.lexology.com/55dc1112-a8aa-48da-82aa73290c805b3f.pdf.

34. Venezuela Nationalizes Her Petroleum Industries, The New York Times ArChives, Aug. 29, 1975, http://www.nytimes.com/1975/08/30/archives/venezuela-nationalizes-herpetroleum-industry-venezuela.html.

35. For a comprehensive list of the legal framework that governs PDVSA, see Petroleos DE Venezuela, S.A., MARCO LeGAL http://www.pdvsa.com/index.php? option $=$ com_content\&view $=$ article $\& i d=6519 \&$ Itemid $=57$ $3 \&$ lang=es(last visited April 30, 2017). 


\section{Constitution of the Bolivarian Republic of Venezuela}

Unique amongst any Venezuelan SOEs (let alone any Venezuelan commercial entities), PDVSA's relationship to the Venezuelan State was explicitly mentioned in Venezuela's constitution. In this respect, there are two Articles that should be pointed out: Articles 302 and 303. While Article 302 established that "[t]he State reserves to itself, through the pertinent organic law, and for reasons of national expediency, the petroleum industry and other industries, operations and goods and services which are in the public interest and of a strategic nature," ${ }^{, 36}$ Article 303 stated:

For reasons of economic and political sovereignty and national strategy, the State shall retain all shares of Petróleos de Venezuela, S.A. or the organ created to manage the petroleum industry, with the exception of subsidiaries, strategic joint ventures, business enterprises and any other venture established or coming in the future to be established as a consequence of the carrying on of the business of Petróleos de Venezuela, S.A. ${ }^{37}$

Thus, the nature of PDVSA's ownership and relationship with the Venezuelan State is enshrined in the constitution: the State reserves for itself the domestic oil industry, and PDVSA is the entity by which Venezuela will manage it.

\section{Organic Law of Hydrocarbons}

The "pertinent organic law" "38 that governs the petroleum industry is the Organic Law of Hydrocarbons (sometimes referred to simply as the "Organic Law" in this Paper). ${ }^{39}$ Within the law, there are four particular articles that are relevant for understanding PDVSA's relationship with the State: Articles 22, 27, 29, and 30. While Articles 22 and 27 establish the kind of State entities that may carry out activities related to hydrocarbons, Articles 29 and 30 govern the relationship between these entities and the State. These Articles read as follows: ${ }^{40}$

36. Constitution of the Bolivarian RePublic of Venezuela, art. 302

37. Constitucion de la Republica Bolivariana de Venezuela Asamblea Nacional Constituyente, Caracas [Constitution of the Bolivarian Republic of VENEZUELA] 1999, art. 302; id. art. 303.

38. Id. art. 302 .

39. LEY ORGÁNICA DE HidRocarbuROS (Venez.) http://www.mpetromin.gob.ve/repositorio/imagenes/file/normativas/leyes/LEY_ORGANICA _DE_HIDROCARBUROS_CORREGIDA.pdf (last visited April 30, 2017).

40. Given that I have not been able to find an official English translation of the Law, all translations referring to this Law are my own. Wherever a translation is made, the original passage in Spanish will be referenced in an accompanying footnote. 
Article 22: The primary activities indicated in article $9^{41}$ of this Law, will be carried out by the State, either directly by the National Executive or via companies of its exclusive ownership. It could also do so via companies in which it retains control of their decisions, by maintaining a stake greater than fifty percent $(50 \%)$ in their equity .... ${ }^{42}$

Article 27: The National Executive may, via Decree in a meeting of the Cabinet, ${ }^{43}$ create any companies of the State's exclusive ownership in order to carry out the activities established within this Law and in the legal forms that it deems convenient, including that of stock corporation with a single shareholder. ${ }^{44}$

Article 29: State-owned oil companies will be governed by this Law and its Regulations, by their own statutes, by the dispositions dictated by the National Executive via the Ministry of Energy and Petroleum, and by the ordinary laws that may be applicable to them. $^{45}$

Article 30: The National Executive, via the Ministry of Energy and Petroleum, will exercise oversight and regulation over the state-owned oil companies and their subsidiaries, both domestically and internationally, and will dictate the guidelines and policies that must be fulfilled on the matters

41. "Primary activities," as defined in article 9 of this Organic Law, are those related to the exploration, extraction, collection, transportation, and storage of hydrocarbons.

42. "Ley OrgánicA de Hidrocarburos" art. 22 (Venez.). The original Spanish reads: "Las actividades primarias indicadas en el artículo 9 de esta Ley, serán realizadas por el Estado, ya directamente por el Ejecutivo Nacional o mediante empresas de su exclusiva propiedad. Igualmente podrá hacerlo mediante empresas donde tenga control de sus decisiones, por mantener una participación mayor del cincuenta por ciento $(50 \%)$ del capital social ......."

43. "Consejo de Ministros" has been translated as "meeting of the Cabinet," as that is the translation provided for the "Consejo de Ministros" in the official English translation of the Venezuelan Constitution. See "Constitution of the Bolivarian Republic of VENEZUELA 1999," art. 71.

44. Ley Orgánica de Hidrocarburos art. 27. The original Spanish reads: "El Ejecutivo Nacional podrá mediante Decreto en Consejo de Ministros, crear empresas de la exclusiva propiedad del Estado para realizar las actividades establecidas en esta Ley y adoptar para ellas las formas jurídicas que considere convenientes, incluida la de sociedad anónima con un solo socio."

45. Id. art. 29. "Las empresas petroleras estatales se regirán por esta Ley y su Reglamento, por sus propios estatutos, por las disposiciones que dicte el Ejecutivo Nacional por órgano del Ministerio de Energía y Petróleo, y por las del derecho común que les sean aplicables." 
referred to in this Law. ${ }^{46}$

Taken together, these articles help us further understand the legal framework that defines the relationship between PDVSA and the Venezuelan State. Article 22 highlights the State's concern on being able to "control" the "decisions" of their state-owned oil companies. Articles 29 and 30, in turn, establish how that control is exerted: by the "disposition," "guidelines," "policies," "oversight," and "regulation" dictated by the National Executive Branch via the Ministry of Energy and Petroleum (which is now called the Ministry of the People's Power of Petroleum and Mining (MPETROMIN)).

\section{PDVSA's Articles of Incorporation and Corporate Statutes}

The final document that should be noted is Decree $\mathrm{N}^{\circ} 2.184,{ }^{47}$ which includes the Articles of Incorporation and Corporate Statutes of PDVSA. This document references some of the content of the articles that have already been mentioned and introduces new mechanisms by which the Venezuelan State relates to PDVSA. While the document's Articles of Incorporation and titles I and II reinforce parts of the regulatory framework seen in the Constitution and the Organic Law, titles III through V further delineate how the Venezuelan State administratively relates to PDVSA.

First, citing the powers conferred by Article 27 of the Organic Law of Hydrocarbons, the Decree ordains that: "A state-owned company ${ }^{48}$ is to be created, under the legal form of Sociedad Anónima, which will fulfill and execute the policies pertaining to hydrocarbons dictated by the National

46. Id. art. 30. The original Spanish reads: "El Ejecutivo Nacional, por órgano del Ministerio de Energía y Petróleo, ejercerá las funciones de inspección y fiscalización de las empresas petroleras estatales y sus filiales, tanto en el ámbito nacional como en el internacional y dictará los lineamientos y las políticas que deban cumplirse sobre las materias a que se refiere esta Ley."

47. Given that I have not been able to find an official English translation of the Decree, all translations referring to this Decree are my own. Wherever a translation is made, the original passage in Spanish will be referenced in an accompanying a footnote.

48. In the original Spanish passage (see Footnote 49), the phrase is "empresa estatal," which could be translated as a "state-owned company," "public sector company," or "state company." Ross Aronstam \& Moritz LLP used "state company" when submitting a complaint by ConocoPhillips against PDVSA (see Complaint at 18, ConocoPhillips Petrozuata B.V. v. Petrolleos de Venezuela S.A., No. 1:16-cv-00904-UNA (D. Del. 2016) (alleging the fraudulent transfer of assets). In Venezuela, entities ("sociedades") in which the state has an equal or greater ownership of $50 \%$ are considered bodies of the public sector ("organismos del sector público"), along with their subsidiaries in which they own $50 \%$ or more of (see "Ley Orgánica de Regimen Presupuestario," title I, art. 1) (establishing the laws that govern public organizations). 
Executive, via the Ministry of Energy and Mines in the activities to which it is mandated."

Title I ("General Dispositions") $)^{50}$ establishes that PDVSA is to be incorporated as a sociedad anónima ${ }^{51}$ and that it must fulfill its stated objectives $^{52}$ under the guidelines and policies established by the National Executive via MPETROMIN..$^{53}$ Title II ("Equity and Shares") ${ }^{54}$ states that all of PDVSA's shareholder equity has been subscribed by and paid for by the Venezuelan State, ${ }^{55}$ and that PDVSA's shares cannot be divested, sold, otherwise transferred, or be encumbered in any form. ${ }^{56}$ These are, in general, legal concepts that have already been introduced in either the Constitution or the Organic Law of Hydrocarbons.

What is new, however, are the concepts introduced in titles III ("The Assembly"), ${ }^{57}$ IV ("Management"), ${ }^{58}$ and V ("Shareholder's Council"). ${ }^{59}$ Broadly speaking, these titles introduce PDVSA's corporate governance.

Title III establishes that the "supreme direction and management" of PDVSA lies in the assembly, ${ }^{60}$ which represents the totality of the company's shares and their decisions. ${ }^{61}$ It further specifies that the assembly is headed by the Minister of Energy and Mines ${ }^{62}$ and that any other ministers selected by the President of Venezuela may assist the assembly and represent the State. ${ }^{63}$ Title III enumerates the attributions of the Assembly in its twelfth clause.

Title IV ("Management") includes chapters on PDVSA's board of directors ${ }^{64}$ president of the board, and vice presidents of the board. The title establishes that the board is the administrative body with the broadest administrative and directive powers of PDVSA ${ }^{65}$ and that it executes the

49. "Estatutos de PDVSA, Decreto No 2.184," art. 1 (Dec. 10, 2002) (Venez). The original Spanish reads: "Se crea una empresa estatal, bajo la forma de Sociedad Anónima, que cumplirá y ejecutará la política que dicte en materia de hidrocarburos el Ejecutivo Nacional, por órgano del Ministerio de Energía y Minas en las actividades que le sean encomendadas."

50. Origianl Spanish: "Disposiciones Generales"

51. Decreto No 2.184: Estatutos de PDVSA, cl. 1.

52. For a comprehensive list of PDVSA's objectives, see Id. cl 2.

53. Id. cl. 1,2.

54. Original Spanish: "Del Capital y de las Acciones."

55. Id.cl. 4.

56. Id.

57. Original Spanish: "De las Asambleas."

58. Original Spanish: "De la Administración."

59. Original Spanish: "Del Consejo del Accionista."

60. Id.cl. 7 .

61. Id. cl. 10.

62. Now called the Minister of the People's Power of Petroleum and Mining.

63. Id. cl. 11 .

64. Origianl Spanish: "Junta Directiva."

65. Id. cl. 16. 
"supreme management of the company's business."66 It further establishes that board members, and those that are to fulfill the roles of board president and vice presidents, are designated to the board and to their roles by the president of Venezuela by decree. ${ }^{67}$ It should be noted that the president of the board is explicitly responsible for the "immediate direction and daily management" of PDVSA's business. ${ }^{68}$

Finally, title V establishes that the shareholder's council, a body responsible for advising the National Executive and the assembly on PDVSA's fulfilment on the guidelines and policies established by MPETROMIN, ${ }^{69}$ is to be formed by three members designated by the president of Venezuela by decree..$^{70}$

Thus, the executive branch of Venezuela, which is headed by the President of Venezuela, can directly select the members of PDVSA's governing bodies (assembly, board, shareholder's council), along with the board's president and vice presidents.

\section{Legal Summary}

These three documents - the Constitution, Organic Law, and Decree $\mathrm{N}^{\mathrm{o}} 2.184$ - are not exhaustive of all the Venezuelan laws that govern PDVSA and its ties to the State. They do however, help flesh out the nature of PDVSA's legal form. While PDVSA is unquestionably a Venezuelan corporation wholly owned by the Venezuelan State, there is a sense that its relationship with the State may go beyond that which is normally ascribed to that between a company and its shareholders.

After all, the State's whole and non-transferable ownership of PDVSA is of constitutional character, motivated by "reasons of economic and political sovereignty and national strategy." A1though PDVSA is not explicitly called an "organ," the Constitution does refer to any entity that may assume PDVSA's current role as an "organ.", A2 Additionally, PDVSA is responsible for the oil industry, which is reserved for the State as being "in the public interest and of a strategic nature."73 Finally, the way in which the State governs PDVSA - as established in both the Organic Law and Decree $\mathrm{N}^{\mathrm{o}} 2.184$ - bring into question the distance between PDVSA and Venezuela's executive branch.

66. Id. $\mathrm{cl} .27$.

67. Id. cl. 17-18.

68. Id. cl. 33 .

69. Id. cl. 39 .

70. Id. cl. 38 .

71. "Constitution of the Bolivarian Republic of Venezuela" art. 303.

72. Id. art. 303.

73. Id. art. 302 . 


\section{B. Assets}

From an asset and operational point of view, there are two traits to be noted about PDVSA: (1) its assets, operations, and employees are overwhelmingly located in Venezuela (and to a lesser extent in the United States, Europe, and the Caribbean) and (2) virtually all of its revenues come from foreign clients, either as exports or as revenues from its foreign subsidiaries. Per PDVSA, the company carries out "exploration, development and production ('upstream') operations in Venezuela,"74 while its "sales, marketing, refining, transportation, infrastructure, storage and shipping ('downstream') operations"75 are located across Venezuela, the United States, Europe, the Caribbean, Latin America, and Asia. Of its foreign operations, it should be noted that PDVSA indirectly owns $100 \%$ of CITGO Petroleum Corporation, which "refine[s] and market[s] ... transportation fuels, petrochemicals and other industrial oil-based products in the United States." ${ }^{, 76}$ PDVSA's corporate group is composed of 368 legally verified subsidiaries in Venezuela and abroad. ${ }^{77}$

Figure 1 provides a simplified organizational chart of PDVSA's corporate structure, as provided by the company itself.

Figure 1: PDVSA Corporate Structure ${ }^{78}$

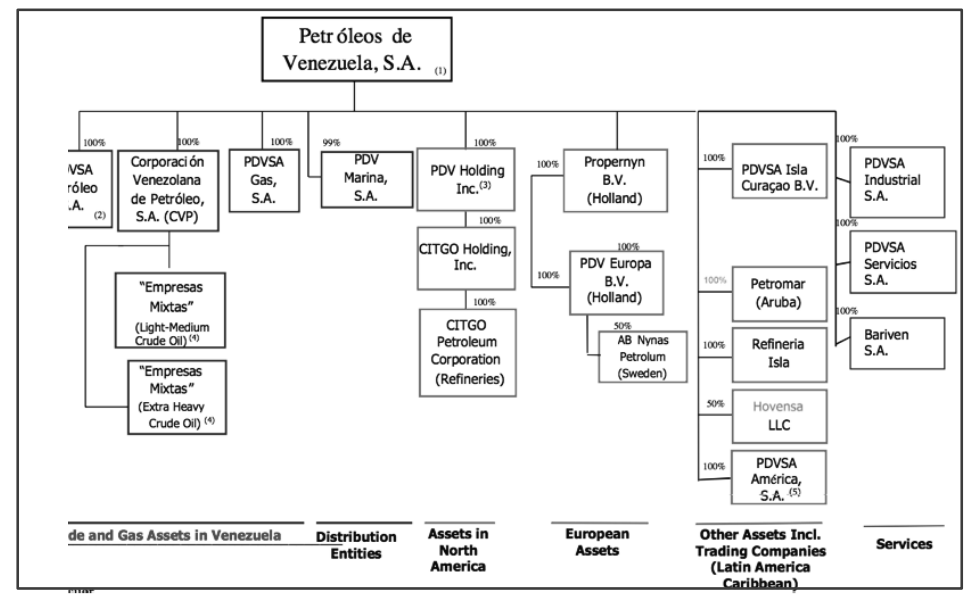

74. Petróleos de VeneZuela, S.A., supra note 30, at 3.

75. Id.

76. Id.

77. Petróleos de Venezuela, S.A., Informe del Comisario 2016, 108 (Dec. 31, 2016).

78. Id. at 9 . 
Via its subsidiaries, PDVSA Petróleo S.A. and Corporación Venezolana de Petróleo, S.A. (CVP), PDVSA operates numerous subsidiaries ${ }^{79}$ tasked with exploring, developing, and producing crude oil, gas, and associated hydrocarbon products in Venezuela. ${ }^{80}$ While Venezuela owns the largest proved reserves of crude oil in the world, ${ }^{81}$ PDVSA boasts of being the "fifth largest vertically integrated oil and gas company ... . seventh in the world in crude oil production, seventh in refining capacity, sixth in proved gas reserves, fifteenth in gas production, and thirteenth in product sales." 82 As stated by PDVSA, these activities are overwhelmingly carried out in Venezuela, which can also be attested by the geographic distribution of its employees and property, plant, and equipment (PP\&E). As Figure 2 and

79. Per the Organic Law of Hydrocarbons, PDVSA must either wholly own its subsidiaries, or operate them as joint ventures legally referred to as empresas mixtas - in which PDVSA must retain control and own a participation greater than $50 \%$.

80. Petróleos de Venezuela, S.A., supra note 30, at 86.

81. EIA BETA, International Energy Statistics: Venezuela, https://www.eia.gov/beta/international/data/browser/\#/?pa $=0000000000000000000008 \& \mathrm{c}=0$ $000000000000000000000000000000000000000000000002 \& \mathrm{ct}=0 \& \mathrm{tl} \_\mathrm{id}=5-$

A\&vs=INTL.57-6-VEN-BB.A\&ord=CR\&cy=2016\&vo=0\&v=H\&start=1980.

82. Petróleos De Venezuela, S.A., supra note 30, at 86 . It should be noted that PDVSA does not own Venezuela's oil reserves: "Venezuela [itself] owns all hydrocarbons while they are underground and the title is passed to the holder of a concession (PDVSA, PDVSA Petróleo S.A., CVP or the JV) at the wellhead." Igor Hernández and Francisco Monaldi, Weathering Collapse: An Assessment of the Financial and Operational Situation of the Venezuelan Oil Industry 52 (CID Working Paper No. 327, 2016). 
Figure 3 show, 96\% of PDVSA's employees and 96\% its PP\&E (by book value $^{83}$ are located in Venezuela. ${ }^{84}$

Figure 2: PDVSA Employees by Geography (Dec 31, 2016) ${ }^{85}$

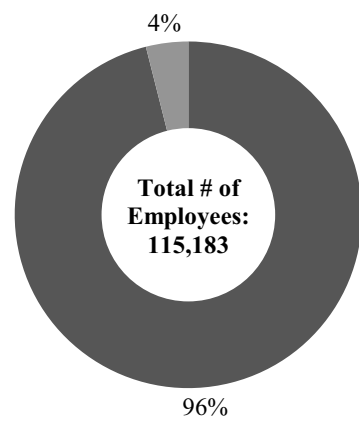

- Venezuela Abroad

83. Caution should always be taken when evaluating PDVSA's financial statements, particularly when a U.S. Dollar (US\$) figure is given for assets, liabilities, cash flows and other items that may be denominated in Venezuelan Bolívares (VEF). Venezuela has multiple official exchange rates between US\$ and VEF, none of which match the black-market exchange rate for US\$. For example, per the latest available data (March 20,2018), while the official SICAD and DICOM rates stand at 13.50, and at 35,280.00 VEF per US\$, the informal black market exchange rate stands at 210,226.73 VEF per US\$. For the formal exchange rates, visitBanco Central de Venezuela at www.bcv.org; for the informal black-market exchange rate, visit DolarToday: Noticias y Dòlar paralelo at www.dolartoday.com).

84. PDVSA does not geographically allocate assets that are not categorized as PP\&E.

85. Petróleos de VeneZuela, S.A., INFORME DE GESTIÓN 2016, 28. 
Figure 3: PDVSA PP\&E by Geography (Book Value; Dec 31, 2016) ${ }^{86}$

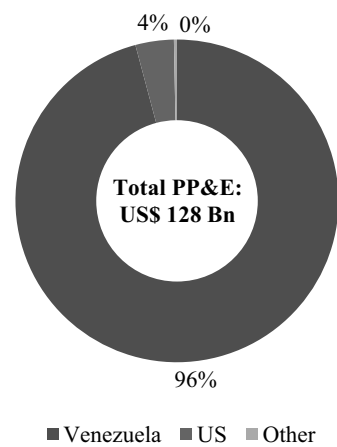

The assets that PDVSA owns abroad are primarily (1) its CITGO subsidiary in the United States, and (2) refineries (or equity interests in refineries) in the United States, Europe, and the Caribbean. CITGO, a wholly owned subsidiary of PDVSA (see

Figure 1), owns three refineries (see Table 1), thirty-eight refined product terminals, and equity interests in ten terminals via joint ventures across twenty-two states in the United States. Additionally, CITGO has access to 125 third-party terminals and has a retail distribution network of 5500 independently owned and operated CITGO retail outlets in the United States. ${ }^{87}$

Including the refineries owned and operated by CITGO, PDVSA owns or has equity interests in twelve refineries outside of Venezuela.

Interestingly, half of PDVSA's refining capacity is found abroad: while PDVSA's refineries in Venezuela have a capacity of $1303 \mathrm{mbpd}$, PDVSA's refineries abroad have a capacity of $1303 \mathrm{mbpd}$ as well (which, if measured proportionally to PDVSA's interest in said refineries, is $1188 \mathrm{mbpd}){ }^{88}$ Table 1 shows the refineries that PDVSA currently owns or has interests in both overseas and in Venezuela. ${ }^{89}$

86. Petróleos de Venezuela, S.A., "Consolidated Financial Statements, 2016," 18.

87. Petróleos de Venezuela, S.A., supra note 30, at A-33.

88. Id. at 106 .

89. It should be noted that the Isla refinery is not actually owned by PDVSA, but rather operated by PDVSA via a lease agreement with the government of Curação. The lease is set to expire on December 31, 2019, and, according to Reuters, will not be renewed. See Sailu Urribarri, Curacao inks deal with China firm to run Isla refinery, RUETERS, Sept. 19, 2016, http://www.reuters.com/article/us-refinery-investment-curacao-idUSKCN11P2GM (discussing an agreement between the governments of China and Curacao to operate a refinery previously operated by PDVSA). Additionally, the Jamaican government has expressed its 
Table 1: PDVSA Refineries ${ }^{90}$

\begin{tabular}{|c|c|c|c|c|c|}
\hline Refineries & $\begin{array}{c}\text { PDVSA } \\
\text { Stake (\%) } \\
\end{array}$ & $\begin{array}{c}\text { Controlling } \\
\text { Company }\end{array}$ & Partnering Firm & $\begin{array}{c}\text { Total Refining } \\
\text { Capacity (mbpd) }\end{array}$ & $\begin{array}{l}\text { PDVS A pro-rata } \\
\text { Capacity (mbpd) }\end{array}$ \\
\hline \multicolumn{6}{|l|}{ Caribbean } \\
\hline Isla, Curação & 100 & PDVSA & none & 335 & 335 \\
\hline Camilo Cienfuegos, Cuba & 49 & Cuvenpetrol & Commercial Cupet & 65 & 32 \\
\hline Jamaica & 49 & Petrojam & $\mathrm{PCJ}^{*}$ & 35 & 17 \\
\hline Haina, Dominican Republic & 49 & Refidomsa PDVSA & Refidomsa & 34 & 17 \\
\hline Total, Caribbean & & & & 469 & 401 \\
\hline \multicolumn{6}{|l|}{ United States } \\
\hline Lake Charles, Louisiana & 100 & CITGO & none & 425 & 425 \\
\hline Corpus Christi, Texas & 100 & CITGO & none & 157 & 157 \\
\hline Lemont, Illinois & 100 & CITGO & none & 167 & 167 \\
\hline Sweeny, Texas & 50 & PDV Sweeny & Conoco Phillips & $0 \%$ & - \\
\hline Total, United States & & & & 749 & 749 \\
\hline \multicolumn{6}{|l|}{ Europe } \\
\hline Nynäshamn, Sweden & 50 & Nynäs & Neste Oil AB. & 29 & 15 \\
\hline Gothenburg, Sweden & 50 & Nynäs & Neste Oil AB. & 11 & 6 \\
\hline Hamburg, Germany & 50 & Nynäs & Neste Oil AB. & 27 & 14 \\
\hline Eastham, England & 25 & Nynäs & Neste Oil AB. & 18 & 5 \\
\hline Total, Europe & & & & 85 & 38 \\
\hline Total, International & & & & 1,303 & 1,188 \\
\hline \multicolumn{6}{|l|}{ Venezuela } \\
\hline CRP, Falcón & 100 & PDVSA & none & 971 & 971 \\
\hline Puerto la Cruz, Anzoátegui & 100 & PDVSA & none & 192 & 192 \\
\hline El Palito, Carabobo & 100 & PDVSA & none & 140 & 140 \\
\hline Total, Venezuela & & & & 1,303 & 1,303 \\
\hline Total & & & & 2,606 & 2,491 \\
\hline $\begin{array}{l}\text { * Petroleum Corporation of. } \\
\text { PPDVSA does not have a par } \\
\text { two units within the Sweeny } \\
\text { and } 58 \mathrm{mbpd} \text {, respectively. }\end{array}$ & ica & $\begin{array}{l}\text { yefine } \\
\text { tillation }\end{array}$ & $\begin{array}{l}\text { at distill cru } \\
\text { elayed coke }\end{array}$ & $P, P D$ & $\begin{array}{l}\text { icipation in } \\
\text { nits are } 110\end{array}$ \\
\hline
\end{tabular}

Furthermore, PDVSA may have significant assets abroad related to the commercialization and transportation of its products. As shown in Figure 4, nearly all of PDVSA's revenue comes from exports or foreign subsidiaries.

interest in acquiring PDVSA's 49\% stake in Petrojam. See Ezra Fieser, Jamaica Plans to Buy Venezuela's Stake in Kingston Refinery, BlOOMBERG MARKeTs, Feb. 1, 2018, https://www.bloomberg.com/news/articles/2018-02-01/jamaica-plans-to-buy-venezuela-sstake-in-kingston-refinery (discussing the intentions of the government of Jamacia to buy PDVSA's stake in an oil refinery after PDVSA deterred an upgrade to the facility).

90. Petróleos de Venezuela, S.A., Informe de Gestión Anual 2016 68, http://www.pdvsa.com/images/pdf/iga/IGA_2016_Compilado.pdf. 
Figure 4: PDVSA Sales (Fiscal Year ended Dec 31, 2016) ${ }^{91}$

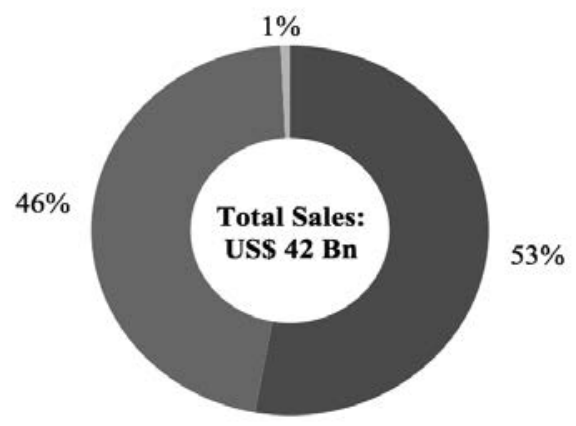

Of those exports and overseas sales, it should be noted that "overseas sales" are primarily generated in the United States. Figure 5 shows sales to external clients (vis-à-vis intergroup transactions) in different countries. Sales to external customers in the United States constitute $46 \%$ of PDVSA's total sales and represent $98 \%$ of all sales from overseas subsidiaries. Finally, when contemplating total crude oil \& refined products exports, they are primarily sent to Asia and North America, as seen in Table 2.

Figure 5: PDVSA Sales to Non-Group Customers (Fiscal Year ended Dec 31, 2016) $)^{92}$

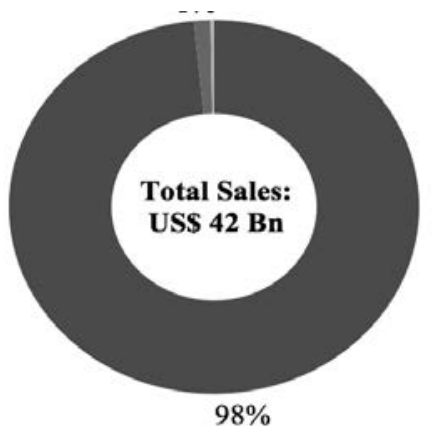

91. Petróleos de Venezuela, S.A., supra note 86, at 23.

92. Id. at 15 . 
Table 2: PDVSA Exports by Geography (mbpd; Fiscal Year Ended Dec 31,

\begin{tabular}{|lrr|}
\hline Crude Oil & mbpd & \\
Asia \& Others & 817 & 45 \\
North America & 734 & 40 \\
Latin America \& Canibbean & 202 & 11 \\
Europe & 66 & 4 \\
\hline Total Crude & 1,818 & 100 \\
& & \\
Refined Products & & \\
Asia \& Others & 211 & 57 \\
North America & 71 & 19 \\
Latin America \& Canibbean & 67 & 18 \\
Europe & 21 & 6 \\
\hline Total Refined Products & 371 & 100 \\
& & \\
Crude Oil \& Refined Products & 1,028 & 47 \\
Asia \& Others & 805 & 37 \\
North America & 20 & 12 \\
Latin America \& Canibbean & $\mathscr{6}$ & 4 \\
Europe & 2,189 & 100 \\
\hline Total Crude Oil \& Refined Products & & \\
\hline
\end{tabular}

This implies that PDVSA, at any given time, may have cash, accounts receivables, inventory, and other forms of working capital abroad as it exports oil and oil-related products. Additionally, PDVSA may also have assets abroad tied to the transportation of said products, such as oil tankers. ${ }^{94}$ This is important as these assets - as well as the refineries - may be susceptible to creditor actions if PDVSA defaults on its obligations, and if said creditors could gain enforceable judgements against PDVSA.

In their article Weathering Collaspe: Assessment of the Financial and Operational Situation of the Venezuelan Oil Industry, Igor Hernández ${ }^{95}$ and

93. Petróleos de Venezuela, S.A., Informe De Gestión 2016, at 74, http://www.pdvsa.com/images/pdf/iga/IGA_2016_Compilado.pdf. It should be noted that "[s]ome of these exports do not generate cash-flow for PDVSA. It is important to point out that shipments to China are largely used for the amortization of different financing agreements made by the Republic of Venezuela within the context of the Joint Venezuelan-Chinese Fund and Great Volume Fund. In addition to that, a portion of the exports is heavily subsidized, because of regional cooperation agreements with countries in Central America and the Caribbean (e.g. Petrocaribe), as well as bilateral agreements, the most important one [being] with Cuba." Hernández and Monaldi, supra note 82, at 14.

94. Hernández and Monaldi, supra note 82, at 48.

95. Igor Hernández is a Professor at the Center on Energy and the Environment (CIEA) at IESA in Caracas, and a Graduate Student Fellow at the Center on Energy Studies at the Baker Institute at Rice University. 
Francisco Monaldi ${ }^{96}$ dedicated a chapter to analyzing PDVSA's assets that may be at risk of being seized by creditors. ${ }^{97}$ As they note, the "precarious cash flow of PDVSA has motivated questions on the exposure of the assets of the company to seizures by creditors, in case there is a credit event on the instruments issued by the company, or by companies that win arbitration awards against the company or the Republic." ${ }^{98}$ In addition to CITGO, CITGO's assets, and the other refineries found abroad, Hernández and Monaldi find that PDVSA's "liquid [and] hard currency assets, ... oil in transit, ships in transit, accounts receivables, inventories, and overseas accounts" ${ }^{\prime 99}$ could be seized. ${ }^{100}$

In summary, PDVSA's assets and operations are overwhelmingly located within Venezuela. However, it does possess relevant assets abroad (primarily in the United States) and it does rely nearly entirely on international sales (substantially from the United States). If PDVSA were to protect its assets from creditors, it would need to consider strategies to do so both in Venezuela and in the United States.

\section{Liabilities}

From a liabilities point of view, it should be noted that PDVSA and its subsidiaries have a highly complex capital structure. PDVSA has issued debt (1) across multiple different subsidiaries, (2) subject to different jurisdictions, and (3) with different degrees of collateral and group guarantees. ${ }^{101}$

Figure 6 attempts to map out PDVSA's financial debt and other relevant liabilities across its group's different entities, using a layout similar to the one PDVSA uses to map its corporate structure (see Figure 1). The debt is organized along the same categories utilized by PDVSA

96. Francisco Monaldi is a Baker Institute Fellow at Rice University, Associate of the Geopolitics of Energy Project at the Belfer Center at the Harvard Kennedy School, and Founding Director and Professor at the Center on Energy and the Environment (CIEA) at IESA.

97. Hernandez and Monaldi, supra note 82, at 48.

98. Id.

99. Id. at 52 .

100. As a side note, Hernández and Monaldi point out that "[o]il in transit shipped as Free on Board (FOB) is not available for enforcement given that property transfer to the purchaser occurs at port and is typically delivered in shipments of third-party tankers. Meanwhile oil shipped through Cost, Insurance, and Freight (CIF), could be attachable and is generally shipped in the PDVSA owned fleet. Most of PDVSA petroleum exports are shipped FOB and PDVSA owned-fleet is held indirectly through subsidiaries." Id.

101. See Appendix 5: PDVSA's Debt Collateral and Guarantees (illustrating in a table debt issuances with collateral or group guarantees). 
when presenting data on its financial debt (as seen in its audited Financial Debt Balance Reports and Financial Statements). ${ }^{102}$

Figure 6 PDVSA Financial Debt \& Other Liabilities (Principal Value); US\$ Million

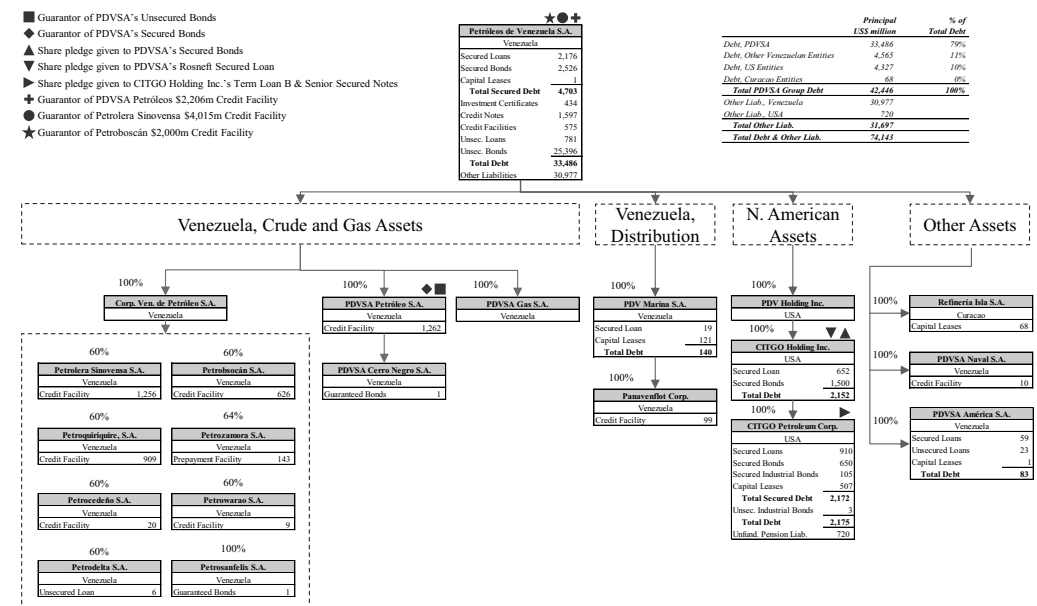

This figure maps out the debt owed by PDVSA along the different legal entities that conform to its corporate group. Debt figures represent principal owed, in US\$ (millions). The percentage figures represent PDVSA's proportional ownership of those entities, where information is available. The country of each entity's location is noted below each's name. The group guarantees and share pledges presented in this Figure are not exhaustive of the group's intergroup guarantees and collateral commitments.

A more detailed debt list - from which Figure 6 draws its data - can be found in Appendix 4: PDVSA's Financial Debt and Other Liabilities. Information on PDVSA's financial debts and other relevant liabilities has been sourced from PDVSA's 2016 Financial Statements, ${ }^{103}$ PDVSA's 2016 Debt Balance Report, ${ }^{104}$ PDVSA's September 2016 Exchange Offering Circular, ${ }^{105}$ and CITGO Petroleum's 2016 Annual Report. ${ }^{106}$ PDVSA

102. The only difference is that, for this Paper, all Credit Notes extended to suppliers have been categorized under "financial debt" rather than "other liabilities."

103. Petróleos de Venezuela, S.A., supra note $86 .$.

104. Petróleos de Venezuela, S.A., "Balance De la Deuda Financiera Consolidada, Petróleos DE Venezuela, S.A." (March 10, 2017), http://www.pdvsa.com/images/pdf/balancededeuda2016.pdf.

105. Petróleos de Venezuela, S.A., supra note 30, at 3.,

106. CITGO Petroleum Corporation, Report for the Fiscal Year Ended December 31, 2016 March 2, 2017. 
arranges its financial debt along the following general categories: Bonds (secured and unsecured), Loans (secured and unsecured), Credit Facilities, Investment Certificates, Capital Leases, and Credit Notes. ${ }^{107}$ In addition to these financial debts, there are other substantial liabilities that should be taken into consideration, which include: CITGO pension and other employee benefit liabilities, PDVSA pension and other employee benefit liabilities, promissory notes and accounts payable owed to related parties(including the Republic of Venezuela, the Venezuelan Central Bank (BCV), and PDVSA's pension funds), advances received from customers (secured and unsecured; bearing interest and amortizations), dividends payable to non-controlling interests, accruals to contractors (other than Credit Notes), and interest payable for the current period.

For further information on these other obligations and their sources, see Appendix 4: PDVSA's Financial Debt and Other Liabilities. In Figure 6 , the first item of the list - the unfunded portion of CITGO's pension funds - is grouped under CITGO Petroleum Corp. Items numbered two through seven in the preceding list are grouped under "Other Liabilities" in PDVSA.

Leaving these "other liabilities" aside, we can see that as a group, most financial debt has been issued by Venezuela-based entities (90\% of the group's total debt), and that most debt has been issued by PDVSA ${ }^{108}$ (79\% of the group's total debt). Most significantly, PDVSA's nine U.S. dollar-denominated secured and unsecured bond series represent $83 \%$ of PDVSA's financial debt, and $66 \%$ of the entire corporate group's financial debt.

Of these nine securities, at least seven ${ }^{109}$ of them (representing US $\$ 21.92$ billion in principal) contain a choice of law clause that stipulates that the indentures will be "governed by, and construed in accordance with, the laws of the State of New York." 110 Additionally, they include a clause in which PDVSA consents to the "non-exclusive jurisdiction of any court

107. Credit Notes correspond to "credit notes that PDVSA signed with some of its main suppliers . . . at an interest rate of $6.5 \%$, a grace period of three months and maturity in three years, with amortizations and interest payable quarterly (PETRóleOs DE VenezuelA, S.A., supra note 86 , at 48 ). These notes were issued with the purpose to "partially convert the outstanding commercial debt maintained with certain commercial suppliers into financial debt" (Petróleos de Venezuela, supra note 30, at 72).

108. See the table in the top right corner of Figure 6: DVSA Financial Debt \& Other Liabilities (Principal Value; US\$ Million).

109. I say "at least" because I have only had access to the Offering Memoranda or Circulars of seven of PDVSA's nine outstanding series issued in U.S. dollars. The two issuances for which I have not been able to access Indentures or Offering Memoranda are the $6.000 \%$ Unsecured Bonds due October 28, 2022, and the $9.750 \%$ Unsecured Bonds due May $17,2035$.

110. Petróleos de Venezuela, S.A., supra note 30 at 156." 
of the State of New York or any United States federal court sitting in the Borough of Manhattan." "111 This means that if investors in these bonds were to seek action against PDVSA on matters relating to these indentures, they could do so in New York courts. ${ }^{112}$

Figure 7: PDVSA Debt, by Type (Principal Value; US\$ million)

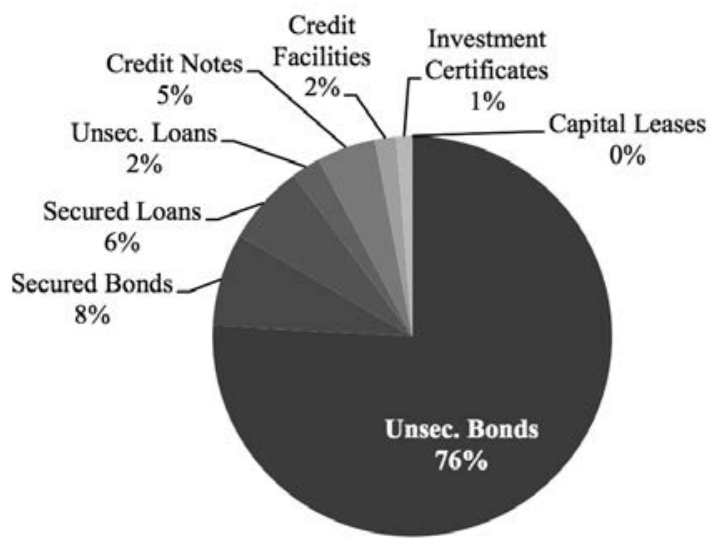

Interestingly, although most of PDVSA's assets are found in Venezuela, its financial debts are overwhelmingly subject to the law and jurisdiction of the State of New York. If PDVSA were to ever seek relief under a restructuring regime (particularly aimed at relieving it of litigation from creditors), then it would be crucial for PDVSA to seek recognition and relief from U.S. courts.

\section{Summary}

Summarizing findings this far, we can observe that PDVSA is: a Venezuelan stock corporation, wholly owned by the Venezuelan State, whose legal form and relationship to the state are governed by Venezuela's Constitution, Organic Law of Hydrocarbons, and Decree $\mathrm{N}^{\circ} 2.184$, whose assets and operations are overwhelmingly found in Venezuela, and in decreasing degrees in the United States, Europe, and the Caribbean, whose revenues are primarily derived from foreign clients (primarily in the United

111. Id. All of the Offering Memoranda of PDVSA's bond issuances I have been able to review have similarly written language.

112. Lea Haber Kuck, The New York Courts Are Open for Business to Foreign Litigants, Corporate Disputes Magazine, April, 2013, at 2-4, https://www.skadden.com/sites/default/files/publications/Skadden_Reprint1_Apr13_proof.p df. 
States and Asia), which features a complex capital structure, of which a substantial portion of liabilities is governed by New York Law and subject to New York jurisdiction.

With this overview in mind, we can now ponder which, if any, form of debtor relief could be pursued by PDVSA, and whether such options would be viable under their corresponding restructuring regimes.

\section{ReStRUCTURING REGIME \& DEBTOR RELIEF ALTERNATIVES}

If PDVSA were to find itself facing financial circumstances that forced it to evaluate its access to restructuring regimes (i.e. a probable or impending inability to finance its obligations), it would first want to determine: the location of assets it needs to protect from creditors, and the jurisdictions under which creditors could initiate actions against the company.

As was previously summarized, while PDVSA's assets are primarily in Venezuela, its financial liabilities are overwhelmingly subject to the law and jurisdiction of the State of New York. Additionally, PDVSA relies on revenues from abroad - a significant portion of which is sourced from the United States in the form of exports or revenues from its U.S. subsidiaries. Therefore, it seems that any viable strategy utilizing relief from restructuring regimes would necessitate recognition in U.S. courts. Given that PDVSA is a Venezuelan firm whose center of main interest (COMI) is Venezuela, it seems that the two most appropriate ways by which to seek recognition would be: A plenary Chapter 11 proceeding in the United States; or a foreign main proceeding in Venezuela, recognized via an ancillary Chapter 15 proceeding in the United States.

Notably, one of the most important forms of relief contained in the U.S. Bankruptcy Code - the automatic stay ${ }^{113}$ - would be available under either type of proceeding (though, admittedly, in varying degrees). ${ }^{114}$

\section{III.1. U.S. Plenary Chapter 11 Proceeding}

There are numerous advantages to seeking insolvency relief via a plenary U.S. Chapter 11 proceeding beyond the automatic stay. The U.S. restructuring regime is one of the most attractive and sophisticated regimes in the world, both from a statutory point of view and due to the extensive

113. 11 U.S.C. $\$ 362$ (2016).

114. While the automatic stay under a plenary Chapter 11 proceeding has an extraterritorial effect, the automatic stay available under an ancillary Chapter 15 proceeding does not. In re JSC BTA Bank, 434 B.R. 334, 336, 348 (Bankr. S.D.N.Y. 2010). Also, while the U.S. Bankruptcy Code immediately provides the automatic stay for foreign main proceedings upon recognition (11 U.S.C. $\S 1520$ ), it does not do so for foreign non-main proceedings. 
experience of the actors involved in proceedings (e.g. judges, legal counsel, financial advisors, investors). As published by Skadden, Arps, Slate, Meagher \& Flom LLP and Affiliates (Skadden):

Chapter 11 of the U.S. Bankruptcy Code is the most welldeveloped law of any insolvency regime in the world for helping troubled companies restructure their affairs. Some nations, like Canada and the United Kingdom, also have insolvency regimes that are very helpful for restructuring businesses, but few others do, and none of these systems is as commercially oriented as Chapter $11 .^{115}$

Beyond the automatic stay on possible domestic creditor actions to pursue their claims against the debtor, the advantages of Chapter 11 include (but are not limited to) (1) the ability to restructure liabilities via a plan of reorganization that requires "less than unanimous stakeholder support,"116 (2) a period of exclusivity of at least 120 days and up to eighteen months in which only the debtor can present a plan of reorganization, ${ }^{117}$ (3) an automatic stay with extraterritorial effect, potentially stymieing creditor actions on the debtor's property anywhere in the world, ${ }^{118}$ and (4) a "presumption that the debtor's management will remain in place rather than be replaced by a trustee." 119 These features provide substantial tools, negotiating leverage, and procedural control to debtors seeking relief.

At first glance, it would seem possible for PDVSA to file for Chapter 11 protection. As expressed in the U.S. Bankruptcy Code, a voluntary case can be "commenced . . . by an entity that may be a debtor," 120 and that "only a person that resides or has a domicile, a place of business, or property in the United States . . . may be a debtor under this title."121

115. Mark S. Chehi, Jay M. Goffman, Chris Mallon, and Mark A. McDermott, Using Chapter 11 to Restructure Non-US and Multinational Companies, SKADDEN (Jan. 16, 2014), https://www.skadden.com/insights/using-chapter-11-restructure-non-us-and-multinationalcompanies.

116. Id. Per the article: "Significantly, for an impaired class to be deemed to have accepted a plan, only one-half of the creditors in that class, holding two-thirds of the debt in that class, must vote in favor of the plan - counting only those who actually vote."

117. 11 U.S.C. $\$ 1121$ (a),(b),(d).

118. "Caselaw indicates that the automatic stay applies to all of a debtor's property, no matter where that property is located in the world; that is, the automatic stay has an extraterritorial effect. However, the worldwide application of the automatic stay is subject to foreign courts' willingness to grant comity, i.e., deference to U.S. law." KIRKLAND \& ELLIS LLP, Distressed DEALMAKING: CHAPTER 11 AND OUT-OF-COURT RESTRUCTURING, (2015).

119. Antony Zacaroli QC and Alexander Riddiford, Schemes of arrangement and Chapter 11 of the US Bankruptcy Code: a comparative view, SouTH SQuARE Digest, Dec. 2015, at 10, http://www.southsquare.com/files/DigestDecember2015.pdf.

120. 11 U.S.C. $\$ 301(a)$.

121. 11 U.S.C. $\$ 109(\mathrm{a})$. 
Although PDVSA is a Venezuelan firm headquartered and mainly operating in Venezuela, it clearly has property in the United States. In fact, several firms with far fewer assets and weaker ties to the United States have successfully petitioned and carried out Chapter 11 proceedings. Table 3 presents a few cases where a debtor's eligibility was challenged on the grounds of not satisfying the requirements set forth in 11 U.S.C $§ 109$ (a), but which were subsequently deemed eligible based on their U.S.

property. $^{122}$

122. For examples of cases in which companies incorporated in foreign jurisdictions have been able to satisfy $\$ 109$ with minimal ties to the United States, despite motions to dismiss the case presented by creditors on the basis of challenging said eligibility of $\$ 109$, see, e.g., In re Aerovias Nacionales de Colom. S.A. Avianca, 303 B.R. 1, 1 (Bankr. S.D.N.Y. 2003) (holding that $\$ 109$ eligibilty is satisfied by even a minimal amount of property); In re GLOBAL OCEAN CARRIERS LTD, 251 B.R. 31, 31 (Bankr. D. Del. 2000) (holding that U.S. bank accounts constitute property for $\$ 109$ eligibility, regardless of the amount of funds in the accounts); In re Axona Int'l Credit \& Commerce, Ltd., 88 B.R. 597, 597 (Bankr. S.D.N.Y. 1988) (finding $\$ 109$ satisfied by the presence of a U.S. bank account). 
Table 3: Foreign Debtors Satisfying §109(a) in Chapter 11 Proceedings

\begin{tabular}{|c|c|c|}
\hline Debtor & $\begin{array}{l}\text { Foreign } \\
\text { Debtors' } \\
\text { Country }\end{array}$ & U.S. Assets \& Operations \\
\hline Avianca $^{123}$ & Colombia & $\begin{array}{l}\text { - } 28 \text { employees }(0.6 \% \text { of its } 4,329 \\
\text { employees worldwide) } \\
\text { - } 24 \% \text { of revenues stemming } \\
\text { from Colombia-U.S. flights } \\
\text { - Aircraft that fly to the United } \\
\text { States }{ }^{126} \\
\text { - Substantial subsidiary }{ }^{127} \\
\text { - U.S. credit card receivables }{ }^{128} \\
\text { - Contract rights (including } \\
\text { leases) }^{129}\end{array}$ \\
\hline Axona ${ }^{130}$ & Hong Kong & $\begin{array}{l}\text { - Substantial bank deposits }{ }^{131} \\
\text { - Property interests }{ }^{132}\end{array}$ \\
\hline $\begin{array}{l}\text { Global } \\
\text { Ocean } \\
\text { Carriers } 133\end{array}$ & $\begin{array}{l}\text { Cyprus, } \\
\text { Singapore, } \\
\text { Liberia }\end{array}$ & $\begin{array}{l}\text { - Stock of U.S. subsidiary } \\
\text { incorporated in Delaware } \\
\text { - Two bank accounts }{ }^{135} \\
\text { - Retainer paid to legal counsel, } \\
\text { held in escrow }{ }^{136}\end{array}$ \\
\hline
\end{tabular}

As noted by the U.S. Bankruptcy Court for the Southern District of New York when judging the eligibility of Avianca, "[c]ases that have construed the 'property' requirement with respect to foreign corporations and individuals have found the eligibility requirement satisfied by even a

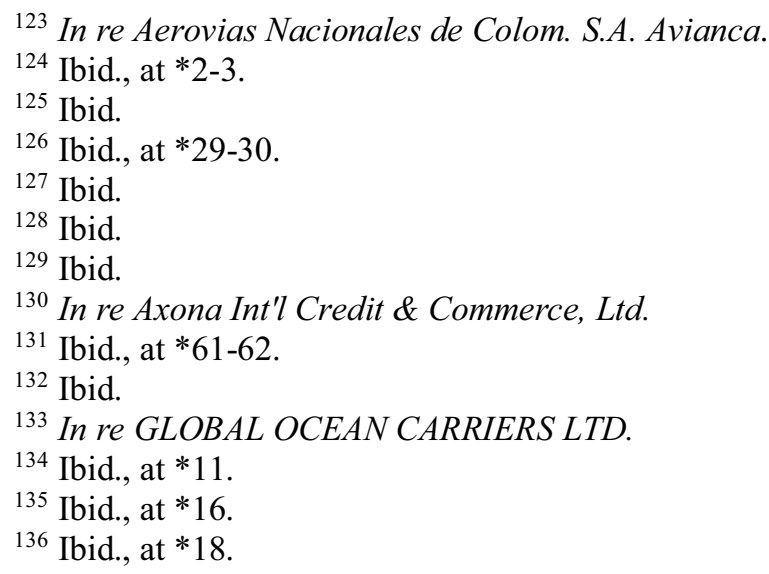


minimal amount of property located in the United States."137 Thus, superficially, it would seem that Chapter 11 may be a possible option for PDVSA.

However, there are at least two significant legal challenges - and one practical difficulty - that a petition by PDVSA would have to overcome. The first is one of eligibility: does PDVSA satisfy the definition of "person" per the U.S. Bankruptcy Code? The second is one of court discretion: even if PDVSA were eligible for Chapter 11 relief, would a U.S. court recognize the case or dismiss it? Finally, even if PDVSA were eligible and its petition recognized, it would still have to deal with the challenge of passing a plan of reorganization without utilizing the "cramdown."

\section{A. Challenge \#1: Eligibility}

As manifested in 11 U.S.C. $\S 109$ (a), "only a person . . . may be a debtor" in the context of a Chapter 11 proceeding. The U.S. Bankruptcy Code states that "the term 'person' includes individual, partnership, and corporation, but does not include governmental unit[.]"138 The definition of "governmental unit," in turn, includes "foreign state" or "department, agency, or instrumentality of . . a foreign state . . ."139 Given what has already been discussed about PDVSA's relationship with the Venezuelan State, could PDVSA be categorized as a "governmental unit" of the Venezuela State, and thus, be ineligible for Chapter 11 relief?

The first issue in addressing this question is that neither "department," "agency," nor "instrumentality" are defined in the U.S. Bankruptcy Code, which means that their definition must be sought elsewhere. In order to address this issue, two venues for possible answers will be explored: (1) a review of how PDVSA has been treated in U.S. courts, and (2) a review of how bankruptcy courts have dealt with these terms.

Regarding existing precedent for how PDVSA has been classified in U.S. courts, it is interesting to note that both PDVSA and one of its subsidiaries have already been deemed to be agencies or instrumentalities of Venezuela (albeit not in the context of bankruptcy). ${ }^{140}$ In fact, PDVSA itself has argued that it is an instrumentality of the Venezuelan State when

137. In re Aerovias Nacionales de Colom. S.A. Avianca, 303 B.R. at 18.

138. 11 U.S.C. § 101(41).

139. 11 U.S.C. $\$ 101(27)$.

140. Crystallex Int'l Corp. v. Bolivarian Republic of Venezuela, No. CV 17-MC-151LPS, 2018 WL 3812153 (D. Del. Aug. 9, 2018) (On August 9, 2018, a few days prior to the publication of this Paper, the U.S. District Court for the District of Delaware determined that PDVSA is not merely an agency or instrumentality of Venezuela, but "that PDVSA is the alter ego of Venezuela"). 
defending itself in certain suits brought against it in U.S. courts. The question of whether PDVSA is an "instrumentality" has already appeared in U.S. courts because of the Foreign Sovereign Immunities Act (FSIA). The FSIA "is the exclusive source of jurisdiction for claims against foreign states or their instrumentalities in the courts of the United States." ${ }^{141}$ Per the FSIA:

For purposes of this chapter -

A 'foreign state' ... includes a political subdivision of a foreign state or an agency or instrumentality of a foreign state as defined in subsection (b).

An 'agency or instrumentality of a foreign state' means any entity - which is a separate legal person, corporate or otherwise, and which is an organ of a foreign state or political subdivision thereof, or a majority of whose shares or other ownership interest is owned by a foreign state or political subdivision thereof, and which is neither a citizen of a State of the United States as defined in section 1332(c) and (e) of this title, nor created under the laws of any third country. ${ }^{142}$

Since Venezuela owns “a majority” of PDVSA's shares, any entity introducing suits against PDVSA in the United States must address the FSIA. In Crystallex International Corp. v. Pdv Holding Inc., PDVSA was referred to by the court as "undisputedly ... an 'agency or instrumentality' of Venezuela." 143 In Helmerich \& Payne Internationall Drilling Co. v. Bolivarian Republic of Venezuela, PDVSA and PDVSA Petróleo conceded to being "agencies or instrumentalities of Venezuela, as that term is defined at 28 U.S.C. $\$ 1603(\mathrm{~b}) . " 144$

Finally, in RSM Prod. Corp. v. Petroleos de Venez. Societa Anonima, PDVSA and PDVSA Petróleo sought to have RSM's complaint dismissed on the grounds that both PDVSA and PDVSA Petróleo were immune per the FSIA. ${ }^{145}$ RSM, however, countered that PDVSA Petróleo was not immune as it did not "fall within the definition of a 'foreign state' under the FSIA."146 The court agreed with RSM that PDVSA Petróleo was not an instrumentality on the basis of its ownership, as it was not directly owned by Venezuela but rather indirectly via Venezuela's ownership of PDVSA (see

141. RSM Prod. Corp. v. Petroleos de Venez. Societa Anonima, 338 F. Supp. 2d 1208, 1210 (D. Colo. 2004).

142. 28 U.S.C. $\$ 1603(a)(b)$.

143. 251 F. Supp. 3d 758, 762 (D. Del. 2017).

144. 971 F. Supp. $2 d$ 49, 53 (D.D.C. 2013).

145. RSM Prod. Corp., 338 F. Supp. $2 d$ at 1210.

146. Id. at 1214. 
Figure 1 for a map of PDVSA's corporate structure). However, the court sought to determine whether PDVSA Petróleo could still be deemed an "agency or instrumentality" of Venezuela by satisfying the definition of "organ." 147 Applying a multifactor analysis on PDVSA Petróleo and its relationship to the Venezuelan State, ${ }^{148}$ the court concluded that it was an organ of Venezuela. Specifically, the court listed the following evidence as supportive of its conclusion:

(1) PDVSA Petróleo was created under a resolution issued by the Venezuelan Ministry of Energy and Mines;

(2) PDVSA was created as an instrument of the Venezuelan state's oil policy, and PDVSA Petróleo is simply the exploration and operating arm of PDVSA;

(3) Venezuelan law requires that oil and gas activities be undertaken for the public welfare and social interest;

(4) PDVSA Petróleo must follow in detail the policies, guidelines, and direction of the Venezuelan government, making its activities public in nature;

(5) PDVSA Petróleo generally is governed by public law in Venezuela; and

(6) PDVSA Petróleo's ownership structure demonstrates a very close tie to the Venezuelan government. Again, PDVSA Petróleo is wholly owned by PDVSA, which is wholly owned by the Venezuelan government. ${ }^{149}$

What is interesting to note about these observations of PDVSA Petróleo's relationship with the Venezuelan State is that they could also be very much said about PDVSA's relationship with Venezuela. It seems that, under the FSIA, PDVSA would be considered an "instrument" or "agency" of the Venezuelan State either by the nature of its ownership or by a broader analysis of its ties and relationship with the Venezuelan State. Although it would be tempting to begin drawing conclusions from these precedents, it should be recalled that none of these cases took place in the

147. Id. at 1215.

148. "Several factors are relevant to an assessment of organ status under the FSIA. These factors include (1) the circumstances surrounding the entity's creation; (2) the purpose of its activities; (3) the degree of supervision by the government; (4) the level of government financial support; (5) the entity's employment policies, particularly regarding whether the foreign state requires the hiring of public employees and pays their salaries; (6) the entity's obligations and privileges under the foreign state's laws; and (7) the ownership structure of the entity. USX Corp. v. Adriatic Ins. Co., 345 F.3d 190, 209 (3rd Cir. 2003). "No one factor is determinative." RSM Prod. Corp., 338 F. Supp. 2d at 1215.

149. Id. at 1215-16. 
context of bankruptcy. For the sake of thoroughness, bankruptcy cases that have dealt with this issue of "personhood" should also be considered.

A relevant bankruptcy case to draw attention to on the matter of defining "governmental unit" ${ }^{150}$ within bankruptcy proceedings is Kentucky Employees Retirement System v. Seven Counties Services Inc., (In re Seven Counties Servs.). ${ }^{151}$ In this case, Seven Counties (a non-profit mental health services provider) had its Chapter 11 filing challenged by the Kentucky Employees Retirement System (KERS), which argued that Seven Counties was a "governmental unit," and thus ineligible for Chapter 11 relief. In settling this complaint, the bankruptcy court had to define the terms "department," "agency," and "instrumentality." For both "department" and "agency," the court developed their definitions from the "plain meaning" of the words as expressed in Black's Law Dictionary. In Black's Law Dictionary, "department" was defined as "a principal branch or division of government," "152 and "agency" as "state offices, departments, divisions, bureaus, boards and commissions." 153

The court found, however, that the plain meaning of "instrumentality" (as provided by Black's Law Dictionary) was of "little assistance."154 Therefore, the court adopted a three-factor analysis that had been developed in In re Las Vegas Monorail, 429 B.R. 770 (Bankr. D. Nev. 2010) to determine whether an entity was to be deemed an "instrumentality." Referring to the work conducted by the court In re Las Vegas Monorail, the court described the three factors of the analysis as follows:

The first [factor] was whether the entity has any of the powers typically associated with sovereignty, such as eminent domain, the power to tax or sovereign immunity. If such powers were weakly present or do not exist, then courts examined the second area, which is whether the entity has a public purpose, and if so, the level of control exerted by the state on the entities activities in furthering the purpose. The more control over day to day operations, the more likely the entity is to be an instrumentality under 11 U.S.C. $\S 101(40)$. The third area is the effect of the state's own designation and treatment of the entity. ${ }^{155}$

150. See Nicholas D. Panzarella, "Determining the Meaning of "Instrumentality" in the Bankruptcy Code," 7 ST. JoHN's BANKR. Res. LiBR. NO. 17 (2015) (engaging in a broader discussion into the definition of "governmental unit" and "instrumentality," in particular).

151. 511 B.R. 431, 431 (Bankr. W.D. Ky. May 30, 2014).

152. Id. at 464. In addition, the court was satisfied with the definition for "department" as it "comport[ed] with federal statutory interpretation of the term in case law." Id.

153. Id. at 465 .

154. Id. at 466 .

155. Id. at 467 . 
When applying this three-factor analysis to PDVSA, it is highly likely that it would be considered an "instrumentality" and thus a "governmental unit." Regarding the first factor - presence of powers typically associated with sovereignty - we have already seen that PDVSA and PDVSA Petróleo benefitted from sovereign immunity per the FSIA in order to dismiss legal actions taken against them by RSM. Additionally, in 2010, when the Venezuelan National Assembly declared Helmerich \& Payne's Venezuelan assets to be of public interest, President Chávez directed PDVSA to seize their assets. Ultimately, PDVSA was the entity that filed the eminent domain actions aimed at expropriating Helmerich \& Payne's assets. ${ }^{156}$ Thus, it seems that PDVSA would satisfy the analysis' first factor for being an instrumentality.

Considering the second factor - public purpose and government control - it also seems that PDVSA would satisfy the definition of an instrumentality. If a court were to apply the same exercise that the District Court for Colorado carried out on PDVSA Petróleo (which allowed it to conclude that it was an "organ" of the Venezuelan State) on PDVSA instead, there would seem to be no apparent reason to believe it would lead to any different conclusion. If anything, such a test would likely reveal an even stronger case on the "public purpose" and "state control" of PDVSA, given the constitutional nature of both its ownership and role.

On the final factor - the State's own treatment of the entity being analyzed - insufficient research has been done for the purposes of this paper to justify proposing a view. However, given PDVSA's likely outcome under the first and second factors of analysis, one would be hardpressed to argue that PDVSA is not an "instrumentality" of the Venezuelan State given their current relationship.

Thus, either by looking at the precedent of how PDVSA has been treated in U.S. courts, or the precedent of how bankruptcy courts have defined the "governmental unit" (particularly "instrumentalities") it is fair to question whether PDVSA would be eligible for Chapter 11 relief. Such a petition would surely be contentious and possibly challenged by creditors or other dissenting parties. ${ }^{157}$

156. Helmerich \& Payne Int'l Drilling Co. v. Bolivarian Republic of Venez., 971 F. Supp. 2d 49, 49 (D.D.C. Sept. 20, 2013).

157. For the sake of thoroughness, it should also be noted that that the U.S. Executive Branch has already acknowledged PDVSA as an "instrumentality" of the Venezuelan Government. In Executive Order 13808, the term "Government of Venezuela" is defined as "the Government of Venezuela, any political subdivision, agency, or instrumentality thereof, including the Central Bank of Venezuela and PDVSA." Exec. Order. No. 13808, 82 Fed. Reg. 41155 §3(d) (August 29, 2017). One may wonder if a U.S. bankruptcy court would consider this designation by the U.S. Executive when identifying PDVSA's "personhood." 


\section{B. Challenge \#2: Avoiding Dismissal by U.S. Courts}

Another significant challenge accompanying the petitioning of a Chapter 11 case is the broad discretion and expansive powers that U.S. bankruptcy courts have to dismiss a Chapter 11 petition or case. The bankruptcy courts' power to dismiss or suspend a case are established in 11 U.S.C. $\$ \S 305$ and 1112 . While $\$ 305$ states that a court can dismiss or suspend a case when "the interests of creditors and the debtor would be better served by such dismissal or suspension," $\$ 1112$ provides for expansive, though not exhaustive, facts and circumstances of inquiry which would allow a court to dismiss a case. ${ }^{158}$ In addition, as was the case in In re Yukos Oil Co., ${ }^{159}$ a court may dismiss a case not on the basis of any one particular reason, but rather on a "totality of circumstances."160

Although the context and circumstances of a potential Chapter 11 filing by PDVSA would be very different to those of Yukos' failed petition, In re Yukos Oil Co. is still illustrative of the kind of quandary a PDVSA filing would put U.S. courts in. It also highlights the broad discretion U.S. bankruptcy courts possess to dismiss a case.

For some background on In re Yukos Oil Co., Yukos used to be an open, joint-stock oil company incorporated under the laws of the Russian Federation. ${ }^{161}$ In 2003, Yukos began facing disputes with the Russian government, which ultimately levied retroactively-assessed taxes of $\$ 27.5$ billion on Yukos. ${ }^{162}$ On November 19, 2004, the Russian government announced it would auction off Yukos' shares in its largest subsidiary. ${ }^{163}$ Reacting to this and the retroactively-assessed taxes, Yukos' management board transferred some banking resources to the United States, hired legal counsel in the United States, and petitioned for a Chapter 11 filing on December 14, 2004. ${ }^{164}$ Steven Theede, CEO of Yukos at the time, testified that the purpose of the Chapter 11 filing was to "obtain a halt in the Russian government's action to enforce its tax claims, to obtain the financial flexibility to obtain loans superior to claims of the Russian government, to finance operations, to restructure tax debt, and to create a surviving entity to seek redress against the Russian government." "165

Facing this case, the court opened its memorandum opinion by remarking that:

158. 11 U.S.C. $\$ \$ 305,1112$.

159. 321 B.R. 396, 396 (Bankr. S.D. Tex. Feb. 24, 2005).

160. Id. at 400 .

161. Id. at 400-01.

162. Id. at 401 .

163. Id.

164. Id. at 399.

165. Id. at 403 . 
This is a very large case . . the debtor is . . a Russian company, and its assets are massive relative to the Russian economy, and, since they are primarily oil and gas in the ground, are literally a part of the Russian land. While there is precedent for maintenance of a bankruptcy case in the United States by corporations domiciled outside the United States, none of those precedents cover a corporation which is a central part of the economy of the nation in which the corporation was created. ${ }^{166}$

This concern over the size and importance of Yukos in relation to the Russian economy turns out to be central in the court's decision to dismiss the case. When enumerating the "totality of circumstances" that led to the dismissal of the case, the court mentions some points that may be relevant when contemplating the viability of a filing by PDVSA. The court held that:

Several facts . . contribute to cause for its dismissal . . . since most of Yukos' assets are oil and gas within Russia, its ability to effectuate a reorganization without the cooperation of the Russian government is extremely limited. Additionally, it is not clear that this court can obtain personal jurisdiction of the pertinent parties sufficient to grant much of the relief sought in the instant case.

The vast majority of the business and financial activities of Yukos continue to occur in Russia. Such activities require the continued participation of the Russian government, in its role as the regulator of production of petroleum products from Russian lands, as well as its role as the central taxing authority of the Russian Federation.

Finally, although the act of state doctrine, standing alone, does not compel dismissal of the instant case, the evidence indicates that Yukos was, on the petition date, one of the largest producers of petroleum products in Russia, and was responsible for approximately 20 percent of the oil and gas production in Russia. The sheer size of Yukos, and correspondingly, its impact on the entirety of the Russian economy, weighs heavily in favor of allowing resolution in a forum in which participation of the Russian government is assured. ${ }^{167}$

Given the location of Yukos' assets (overwhelmingly in Russia), Yukos' size in relation to the Russian economy, and the degree of involvement of the Russian government in Yukos' operations, the bankruptcy court was unwilling to carry out a case without the acquiescence and "assured" participation of the Russian government. ${ }^{168}$

166. Id. at 399 .

167. Id. at 410-11.

168. It is instructive to compare In re Yukos Oil Co. with In re Aerovias Nacionales de Colomb. S.A., and how the Bankruptcy Court for the Southern District of New York ruled in that case. Avianca, a Colombian airline, filed for Chapter 11 relief in the United States on 
Although a voluntary Chapter 11 petition carried out by PDVSA would presumably count with the support of the government, the precedent set by Yukos should establish some serious doubts concerning U.S. courts' willingness to recognize such a petition.

In In re Yukos Oil Co., the bankruptcy court was likely correct in judging that, given Yukos' systemic importance to the Russian economy, and that nearly all of its assets were in Russia, a proceeding would be futile without the explicit approval of the Russian government. If a U.S. court felt uncomfortable recognizing Yukos due to its size relative to the Russian economy, how comfortable would a U.S. court feel presiding over a case involving PDVSA, given its role in the Venezuelan economy? Recall that PDVSA owns and controls the entire hydrocarbons industry for the Venezuelan State. PDVSA is "a driver of Venezuela's economy, a key source of the government's revenues and the country's primary source of foreign exchange." 169 Via numerous taxes, royalties, dividends, social development programs, transfers, and cash-for-oil loans, ${ }^{170}$ PDVSA has historically been a critical source of funding for the Venezuelan State and its numerous social policies.

March 21, 2003. Beginning on April 11, 2003, some of its creditors challenged the filing, arguing that it should be dismissed pursuant to 11 U.S.C. $\S \$ 305(a)$ and 1112(b). Regarding $\S 305$ (a), the creditors argued that "it would not be in the 'best interests' of the Debtors or their creditors to allow this case to proceed, and that Avianca should be compelled to file in Colombia. The movants argue that Avianca's choice of forum creates delay and uncertainty for all creditors (but especially for those in the United States), demonstrates bad faith, and allows depletion of the airline's assets by its foreign creditors, who may either receive voluntary payments from the Debtors in satisfaction of prepetition debts, or, being beyond this Court's effective jurisdiction, can ultimately collect upon their outstanding debts free of the restraint of U.S. law.” In re Aerovias Nacionales de Colom. S.A. Avianca, 303 B.R. at 78 .

On $\S 1112$ (b), the creditors held that the "Debtors will never be able to confirm an effective plan of reorganization when a majority of their creditors are not subject to this Court's effective jurisdiction and there is no parallel proceeding in Colombia." Id.

The Court, however, sustained Avianca's Chapter 11 proceeding on numerous grounds, including that (1) there was no showing that Avianca could have obtained jurisdiction over its lessors and other major financial creditors in Colombia, (2) the Colombian counterpart of Chapter 11, Law 550, was only four years old and relatively untested, particularly in large cases, (3) that the great bulk of Avianca's creditors had been well served by the proceedings, (4) the fact that many of Avianca's principal creditors were in the United States, and that major Colombian parties were both willing and fully participating in the proceeding, and (5) that there would likely have been extensive litigation over "whether Law 550 [met] each of the criteria ... in order to be entitled to recognition [in the United States]." Id. at 16.

In other words, the court's support for Avianca's filing was crucially based on the willing support and participation of Avianca's Colombian counterparties in the Chapter 11 proceeding, and the fear that U.S. recognition of a Colombian proceeding would be "hotly contested," and thus a worse alternative compared to Chapter 11. Id.

169. MoOdY's InVESTORS SERVICE, supra note 6, at 1.

170. Hernández and Monaldi, supra note 82, at 22-26. 
The key problem in Yukos, however, was not Yukos's size, itself, but rather that it demanded the need for jurisdiction over or participation of the Russian government. This raises the question: what guarantees could a U.S. bankruptcy court offer the Venezuelan government in order to convince the Venezuelan government to submit itself to the proceedings and rulings of a U.S. federal court?

Given the number of issues raised in In re Yukos Oil Co, one can only speculate as to how a court would react when confronted by the "totality of circumstances" presented by a Chapter 11 filing by PDVSA. ${ }^{171}$ Surely it is difficult to envisage that any U.S. bankruptcy court would feel entirely at ease with all the contentious elements that such a petition may raise.

\section{Challenge \#3: A Practical Procedural Obstacle in Passing a Plan}

Beyond the matters of eligibility and recognition, there is also a significant practical issue that should be addressed: the challenge of passing a plan of reorganization approved by all creditor classes. If PDVSA pursued Chapter 11 relief to impair its creditors and Venezuela sought to retain ownership over any of PDVSA's shares, let alone the $100 \%$ required by Venezuela's Constitution and Decree $\mathrm{N}^{\circ} 2.184$, then a plan of reorganization presented by PDVSA would require the approval of all impaired creditor classes. Per the "absolute priority rule," 172 PDVSA would not be able to use a "cramdown" to impose a plan on dissenting impaired creditor classes.

This implies that a PDVSA Chapter 11 would be a highly consensual affair, ${ }^{173}$ requiring the approval of creditors representing at least two-thirds

171. Such a "totality of circumstances" would only be aggravated were the sanctions introduced by Executive Order 13808 (or similar public policy instruments) to remain extant in the event of a Chapter 11 filing.

172. The "absolute priority rule" provides that "a nonaccepting class of creditors or interest holders cannot be compelled to accept less than full compensation while a more junior creditor or equity holder receives anything or retains its interest in the debtor under the plan" Gary L. Kaplan, Understanding The Rules of Bankruptcy Cramdown, LAW 360, Sept. 4, 2013, https://www.law360.com/articles/468678/understanding-the-rules-of-bankruptcy-

cramdown. As delineated in 11 U.S.C. $\$ 1126($ b), the U.S. Bankruptcy Code provides that a plan that is rejected by an impaired class may still be confirmed if (1) it does not unfairly discriminate against impaired, nonaccepting creditors, (2) is fair and equitable, and (3) satisfies all other provisions of 11 U.S.C. $\$ 1129$ (a). The "absolute priority rule" refers to the "fair and equitable" treatment requirement. For a further discussion of the U.S. Bankruptcy Code's cramdown provisions, see Kaplan, Understanding The Rules of Bankruptcy Cramdown.

173. There may be an exception to this under the "new value" doctrine, wherein "old equity holders may retain their interests by contributing new money or money's worth that is substantial and essential to the company's reorganization efforts, even if there are creditors that would remain impaired." (Robin Bicket White, The New Value Exception to the Absolute 
of claims in amount, and more than one half in number in each impaired class. ${ }^{174}$ Conversely, this means that any dissenting creditor (or group of creditors) seeking to block a plan of reorganization could do so by simply owning more than a third of any impaired class.

Given this constraint, if PDVSA ever sought Chapter 11 relief, it would likely attempt to do so as a pre-negotiated or pre-packed plan. ${ }^{175}$ The motivation for doing so would be to minimize the time spent in bankruptcy and reduce the risk of losing control of the process to any holdouts over the course of a proceeding. Attempting to carry out a prenegotiated or pre-packaged filing, however, may have the counterproductive effect of informing potentially dissenting creditors of PDVSA's intentions, granting them time to prepare legal challenges against an eventual proceeding.

Priority Rule is Alive and Well after 203 North LaSalle, Frost TOdD BROwn, http://www.frostbrowntodd.com/resources-1564.html (last visted May 27, 2017)). (Kaplan, supra note 172). In other words, "equity holders ... invest new capital to 'buy back' their equity interests ... while the equity holders receive new equity in the reorganized debtor, the equity holders also provide value to the estate in the form of compensation for such interest. Notably, the value does not have to be enough to provide full payment to a nonaccepting class of unsecured creditors." Kaplan, supra note 172.

Although "courts have not applied the new value doctrine evenly," (Kaplan, supra note 172) the U.S. Supreme Court has made it clear that existing shareholders cannot be given the exclusive opportunity to purchase new equity (see Bank of Am. Nat'1 Tr. \& Sav. Ass'n v. 203 N. Lasalle St. P'ship, 526 U.S. 434, 434 (1999) (holding that the debtor could not use cramdown to approve a reorganization plan when the plan violated the absolute priority rule). Thus, the process by which new interests are offered may be legally viable, as long as it is open to bidders in a "market-driven auction process" (Kaplan, supra note 172). For further discussion on the new value doctrine, see Kaplan, supra note 172; Bicket White, supra note 173; and Dana Hall, Plucked From the Bargain Bin: Testing the Limits of the new Value Exception to the Absolute Priority Rule, Weil BankruPtcy Blog (March 6, 2013), https://business-finance-restructuring.weil.com/chapter-11-plans/plucked-from-the-bargainbin-testing-the-limits-of-the-new-value-exception-to-the-absolute-priority-rule/.

174. 11 U.S.C. $\$ 1126(c)$.

175. "In a classic reorganization, the debtor files a bankruptcy petition, eventually negotiates a plan of reorganization with its creditors, seeks court approval of a disclosure statement, and then solicits votes in favor of the plan .... With a prepackaged bankruptcy, on the other hand, the debtor negotiates its bankruptcy plan, arranges dip financing, if necessary, and solicits votes on the plan before ever filing bankruptcy. Upon filing its bankruptcy petition, the debtor will file its disclosure statement, its plan, the results of its prepetition solicitation, and a motion seeking both approval of the disclosure statement and confirmation of the plan. Courts will consider the disclosure statement and confirm the plan in a single hearing near the outset of the case. A renegotiated plan generally refers to a plan that is agreed to, at least in concept, by the major constituents of the debtor. The process of soliciting bids does not officially begin, however, until some time after the case is filed." Steven M. Hedberg and Brain A. Jennings, Prepackaged and Prenegotiated Ch. 11 Plans, LAw 360 Sept. 2, 2009, https://www.law360.com/articles/120120/prepackaged-andprenegotiated-ch-11-plans. 
Thus, even if PDVSA were eligible for Chapter 11 relief, and even if it achieved recognition by U.S. courts, it would still have to navigate the difficulties of passing a fully consensual ${ }^{176}$ plan of reorganization.

\section{VENEZUELAN FOREIGN MAIN PROCEEDING \& ANCILLARY CHAPTER 15 RECOGNITION}

PDVSA could alternatively seek to avail itself of relief in the United States by initiating a proceeding in Venezuela, and then seek recognition of that proceeding in an ancillary Chapter 15 case in the United States. ${ }^{177}$ Although such a strategy may initially appear theoretically possible, it unfortunately would face significant challenges of eligibility, limited relief, or outright dismissal in U.S. courts.

\section{A. Challenge \#1: Eligibility}

At first glance, this path would seem to be a viable way by which to skirt the issue of PDVSA's "personhood." Sections 1515 and 1517 of the U.S. Bankruptcy Code, which deal with the "Application for recognition",178 and "Order granting recognition,",179 only refer to the "foreign representative" 180 and the "foreign proceeding," and do not include any eligibility requirements demanded from the "debtor." Additionally, under the definitions of Chapter 15, a "debtor" "means an entity that is

176. "Fully consensual" here implies a plan that is accepted by all creditor classes. Such a plan could be rejected but still imposed upon creditors representing one-third of claims in amount and one-half in number across all impaired classes.

177. Since PDVSA alerts its creditors that it may be subject to Venezuelan bankruptcy or insolvency laws as part of the "Risk Factors" in the Offering Memorandums/Circulars of its notes (see Petróleos DE VenezUeLA, S.A., supra note 30, at 24). This Paper assumes that a PDVSA Venezuelan insolvency proceeding would follow the existing insolvency statutes in Venezuela's Commercial Code.

However, it should be noted that this issue may not be as straightforward as it seems. Per Roland Pettersson Stolk's paper on the subject (see Roland Pettersson Stolk, PDVSA's Bankruptcy: A look from Venezuelan Law, in the context of a Default, (LEC Abogados Working Paper, 2017), https://papers.ssrn.com/sol3/papers.cfm?abstract_id=3064214). There are outstanding debates on (1) whether PDVSA can file for bankruptcy in Venezuela, and (2) assuming it could declare bankruptcy, whether such a proceeding would be governed by the statutes of the Commercial Code or by the statutes of Venezuelan Administrative Law (which apply to proceedings involving the Venezuelan State and other public sector entities).

178. 11 U.S.C. $\$ 1515$.

179. 11 U.S.C. $\$ 1517$.

180. 11 U.S.C. $\$ 101$ (24): "The term “"foreign representative" " means a person or a body, including a person or body appointed on an interim basis, authorized in a foreign proceeding to administer the reorganization or the liquidation of the debtor's assets or affairs or to act as a representative of such foreign proceeding." 
subject of a foreign proceeding.", An "entity," in turn, under the definition of the Bankruptcy Code, "includes person, estate, trust, governmental unit, and United States trustee." "182 This definition of "debtor" differs from that which is found in 11 U.S.C. $\$ 109$, crucially including "governmental unit" by defining a "debtor" as an "entity" and not as a "person." Although peculiar, this difference may make sense, as $§ 109$ only explicitly mentions Chapters $7,9,12$, and 13 , and never makes any reference to Chapter 15. Thus, it seems, the question of whether PDVSA is a "person" or a "governmental entity" may be irrelevant, if PDVSA were seeking relief in the United States under an ancillary Chapter 15 proceeding.

However, it is unclear whether PDVSA's eligibility would go unchallenged. In In re IR Bank Resolution Corp. (In Special Liquidation), ${ }^{183}$ the U.S. Bankruptcy Court of the District of Delaware stated that "only a "person' may be a debtor in a Chapter 15 case."184 The statement is odd: it seems to apply an eligibility requirement concerning Chapter 11 (i.e. the definition of debtor under 11 U.S.C. § 109(a)) to Chapter 15, whose sections never stipulate such a requirement. Nonetheless, this statement introduces the question of whether a court would require PDVSA to satisfy the definition of "person" in order to be deemed eligible for a Chapter 15 proceeding. It would go to reason that if PDVSA were to be classified as a "governmental unit" and not a "person" for purposes of a plenary Chapter 11 proceeding, so too would it be classified as a "governmental unit" within the context of an ancillary Chapter 15 proceeding, making it ineligible for relief either way.

On the other hand, in Drawbridge Special Opportunities Fund LP v. Barnet (In re Barnet), ${ }^{185}$ the U.S. Court of Appeals for the Second Circuit made a nuanced applicability of 11 U.S.C. \$109(a) to Chapter 15 proceedings, specifically on the issue of the definition of "debtor." In the aforementioned case, the court ruled that 11 U.S.C. $\$ 109$ (a) also applies to Chapter 15, as 11 U.S.C. \$103(a) states that Chapter 11 (which includes 11 U.S.C. \$109(a)) applies "in any case under Chapter 15."186 However, the Court specified that this only pertains to the property requirement imbedded in 11 U.S.C. $\$ 109$ (a), and not to the definition of "debtor." The Court distinguished that the definition of "debtor" differed between

181. 11 U.S.C. $\S 1502$.

182. 11 U.S.C. $\$ 101(15)$

183. 59 Bankr. Ct. Dec. (LRP) 135, 135 (Bankr. D. Del. Apr. 30, 2014).

184. $I d .$.

185. 737 F.3d 238, 238 (2d Cir. 2013).

186. Id. at 249 . 
Chapters 11 and 15, in that "Section 1502 supplants Section 101 - i.e., it supplants the definition of debtor within the context of Chapter 15.,"187

Summarily, though inconclusively, it would seem that a PDVSA foreign main proceeding would be eligible to seek Chapter 15 relief. However, given the Court's statement in In re IRBC, it is unclear whether such a filing's eligibility would be entirely uncontested.

\section{B. Challenge \#2: Avoiding Dismissal or Limited Relief from U.S. Courts}

An additional set of problems with the recognition of a foreign main proceeding in Venezuela stems from Venezuela's insolvency regime. The weaknesses intrinsic to Venezuela's insolvency regime could allow U.S. courts to dismiss such a proceeding entirely, or significantly limit the relief provided to PDVSA. Section 1522 of the U.S. Bankruptcy Code provides that any relief granted upon filing or recognition of a Chapter 15 case can "only" be given "if the interests of the creditors and other interested entities. . . are sufficiently protected." "188 Furthermore, any additional relief or support from U.S. courts can only be provided if the foreign proceeding may reasonably assure:

Just treatment of all holders of claims against or interests in the debtor's property; protection of claim holders in the United States against prejudice and inconvenience in the processing of claims in such foreign proceeding; prevention of preferential or fraudulent dispositions of property of the debtor; distribution of proceeds of the debtor's property substantially in accordance with the order prescribed by this title .... ${ }^{189}$

Finally, 11 U.S.C. $\$ 1506$ allows U.S. courts to refuse any "action governed" by Chapter 15 if such an action were "manifestly contrary to the public policy of the United States." 190 This means that if "the procedural fairness of the foreign proceeding is in doubt" ${ }^{191}$ or if a "U.S. constitutional or statutory right' is severely impinged," a U.S. court can refuse to grant relief in or outright dismiss a Chapter 15 case. ${ }^{192}$ Could a Venezuelan foreign proceeding satisfy all these conditions for relief? It

187. Id.

188. 11 U.S.C. $\S 1522(a),(b)$.

189. 11 U.S.C. $\S 1507$.

190. 11 U.S.C. $\S 1506$.

191. In re Ir. Bank Resolution Corp. (In Special Liquidation), No. 13-12159 (CSS), at*57

(Bankr. D. Del. Apr. 30, 2014).

192. Id. 
would certainly face multiple hurdles given the significant deficiencies inherent to Venezuelan proceedings. ${ }^{193}$

Venezuela's insolvency regime is an archaic, liquidation-oriented system, inadequate for the reorganization of an on-going concern, let alone one of the size and complexity of PDVSA. ${ }^{194}$ According to the World Bank's Doing Business data sets on Resolving Insolvency, Venezuela's insolvency regime ranks among the worst-performing in the world. Of the 167 countries for which there was data ${ }^{195}$ Venezuela ranked 165th for its insolvency regime in the general Resolving Insolvency ranking, 164th on recovery rates for secured creditors, among the bottom twenty-five countries in terms of the strength of its insolvency framework, and among the eighteen worst in terms of the duration of the proceeding. ${ }^{196}$ This lackluster performance may be explained, in part, due to the shortcomings of Venezuela's insolvency statutes, legal system, and courts.

\section{Venezuelan Insolvency Regime}

The Venezuelan insolvency regime is codified in the Venezuelan Commercial Code ("Código de Comercio"), ${ }^{197}$ Articles 898 through 1081. If a debtor is unable to pay its obligations as they come due, the Venezuelan insolvency regime provides for two possible proceedings: 1) Bankruptcy ("Quiebra"), and (2) Moratorium ("Atraso"). Whether a debtor is eligible for one or the other depends on a balance sheet test: if a debtor's assets in liquidation would be insufficient to pay off all liabilities,

193. Although this Paper assumes the absence of the U.S. sanctions introduced by Executive Order 13808 (or similar public policy instruments) it is worth noting the risk that these pose considering 11 U.S.C. $\$ 1506$. As written by Cooper and Walker: "the existence of U.S. sanctions . . . would no doubt be used by opponents to argue that granting Chapter 15 relief to PDVSA would be contrary to U.S. policy. Whether such an argument would be successful is hard to predict, but at a minimum we believe it would weigh heavily on any court addressing these issues." Cooper and Walker, supra note 12, at 20.

194. Pedro Jiménez and Amanda Parra Cristie, supra note 14, at 2; Carlos Acedo Sucre and Luisa Acedo de Lepervanche, Venezuela: Insolvency Under Venezuelan Law, MONDAQ, Apr. 11 , 2005 , http://www.mondaq.com/x/31915/Credit+Control+Cashflow+Management/Insolvency+Und er+Venezuelan+Law+; U.S. Department of State, Investment Climate Statements, https://www.state.gov/e/eb/rls/othr/ics/investmentclimatestatements/\#wrapper.

195. Certain countries included in the data sets have no accompanying data and are all ranked in last place $\left(169^{\text {th }}\right)$ in the data set's overall ranking. These countries are: Angola, Bhutan, Cabo Verde, Comoros, Dem. Rep. Of Congo, Equatorial Guinea, Eritrea, Grenada, Guinea-Bissau, Haiti, Iraq, Kiribati, Lao PDR, Libya, Mauritania, Saudi Arabia, Somalia, South Sudan, St. Kitts and Nevis, St. Vincent and the Grenadines, and Timor-Leste.

196. See Appendix 6: Doing Business, Resolving Insolvency Rankings.

197. "Código DE Comercio" [Commercial Code] Gaceta № 475 Extraordinaria (December 21, 1955) (Venez.) http://www.wipo.int/edocs/lexdocs/laws/es/ve/ve029es.pdf. 
then it is eligible for Bankruptcy. If, on the other hand, a debtor's assets in liquidation would be sufficient to pay off all liabilities, then it is eligible for a Moratorium.

The Bankruptcy proceeding is "akin to a liquidation": ${ }^{198}$ once a voluntary or involuntary ${ }^{199}$ case is recognized by a Venezuelan Commercial Court, the presiding judge orders the judicial possession of the debtor's assets, books, documents, and correspondence and appoints a trustee to manage and liquidate the debtor on behalf of creditors. ${ }^{200}$ Although a debtor may reach agreements with creditors on a unanimous basis at any moment during the proceeding, ${ }^{201}$ "bankruptcy is neither a protection nor a benefit. In the ordinary course of events, bankruptcy leads to the liquidation of the bankrupt estate." 202 If PDVSA sought to be restructured and rehabilitated (rather than simply liquidated), this does not seem to be a proper option to be considered.

The Moratorium, on the other hand, does entertain a more viable option for reaching agreements with creditors. Once a Venezuelan Commercial Court recognizes a Moratorium (which can only be initiated voluntarily), ${ }^{203}$ the debtor may be given up to twelve month ${ }^{204}$ to either pay off all of its debts or reach an agreement with its creditors. During this period, the debtor remains in possession of its assets and management, ${ }^{205}$ and enjoys relief in the form of an automatic stay against any prepetition unsecured or non-privileged claim. ${ }^{206}$ In addition, the Moratorium does contain a cramdown provision, in which an agreement binding all creditors

198. Pedro Jiménez and Amanda Parra Cristie, supra note 14, at 2.

199. Bankruptcy proceedings may be initiated by either the debtor, one or more creditors, or Venezuelan Commercial Courts. Código de CoMERCio [COMMERCIAL Code] art. 907, 911, 913, 914, 924, 925, 932 .

200. Id. art. 937, 939, 940.

201. Id. art. 1009.

202. Baker McKenzie, Global Restructuring \& Insolvency Guide 466 (2016).

203. Código de COMERCio[Commercial Code] art. 898.

204. This period may be extended for up to another twelve months if creditors representing at least $50 \%$ of unpaid liabilities agree to an extension. Id. art. 908.

205. Per articles 898, 900, 902, 903, and 904 of the Venezuelan Commercial Code, "debtors continue to operate and administer their day-to-day business within the scope of the plan for liquidating outstanding debts. Nevertheless, the court imposes several restrictions on the debtor in respect of the management and disposition of its assets. The debtor must obtain prior approval of the court to sell, pledge, mortgage, borrow money, compromise, collect receivables, make payments or perform any other acts which are necessary for the purposes of liquidating its assets and satisfying its creditors. The debtor is also subject to supervision by the creditors' committee. In addition, under certain exceptional circumstances, the debtor also may be completely deprived by the court of the management of its business." BAKER McKenZie, Global Restructuring \& InSOLVENCY Guide, 465 (2016).

206. Código de COMERCio[COMMERCIAL CODE] art. 905. 
may be passed with the support of creditors representing $75 \%$ of the debtor's liabilities.

Although the Moratorium seems promising as a court supervised insolvency proceeding that confers a debtor with relief and a negotiating forum, it is still a highly imperfect scheme. Principally, the Moratorium is remarkably rudimentary.

The process by which a debtor may reach an agreement with its creditors is entirely contained in Article 906 of the Venezuelan Commercial Code, which reads as follows: $:^{207}$

During the amicable liquidation, the debtor may enter with its creditors into any other arrangement or agreement that grants it extensions on its moratorium; and even reductions in interests and part of the principal; but in order for it to be valid, it will require the approval of all creditors.

[An agreement] could also be validly established by a majority of creditors representing, at a minimum, three fourths of the liabilities, so long as the creditors agreeing with the debtor agree on and ensure the means of addressing the results of any dispute with dissenting creditors, so that dissenting creditors are assured to recover what they could otherwise receive, according to their respective rights, from a prudently administered liquidation.

A copy of the agreement shall in all cases be given to the Court, and if the agreement has received unanimous approval from creditors, the Court shall so declare it so that the agreement may produce all of its effects.

If only the indicated majority is reached, the Court will judge in oral proceedings all dissents, if they pertain to any right held by the respective party that was denied and damaged by the agreement, after hearing the creditor's committee; and its decision may only be appealed ${ }^{208}$ in the Superior Courts. But if the dissents do not pertain to disputed rights, the Court will limit itself to verifying the majority; and having heard the creditor's committee, will approve the agreement. ${ }^{209}$

207. Given that I have not been able to find an official English translation of the Commercial Code, all translations referring to this Document are my own. Wherever a translation is made, the original passage in Spanish will be referenced in an accompanying footnote.

208. Initiating an appeal does not suspend enforcement of the commercial court's judgement.

209. "Durante la liquidación amigable podrá el deudor celebrar con sus acreedores cualquier otro arreglo o convenio que le conceda mayores moratorias; $y$ aun quitas de intereses y hasta de parte de los capitales; pero para que tenga validez necesitará el acuerdo de todos los acreedores.

También podrá establecerse válidamente con la sola mayoría de los acreedores que representen, por lo menos, las tres cuartas partes del pasivo, con tal que los acreedores que 
Thus, with the approval of the court, the debtor may reach agreements binding on all creditors with the support of creditors representing $75 \%$ of its liabilities. The agreement may extend its moratoriums, reduce interest and/or reduce principal owed. That is the full extent of the framework governing agreements: there is no mention of voting by creditor classes, no mention of how claims held by insiders or related parties ${ }^{210}$ are to be treated, nor any mention of how a creditor's claims may be protected if it has appealed the commercial court's recognition of an agreement.

Additionally, the Moratorium fails to contemplate how the insolvency of more than one entity of a corporate group may be addressed. There are no provisions for any forms of joint administration, substantive consolidation (nor deemed or partial), or any other manner of comprehensive corporate group proceeding. Given the intercompany guarantees of PDVSA's liabilities (see Appendices 4 and 5), this is a relevant consideration. The prospect that a restructuring of PDVSA's liabilities may unravel into multiple, separate, and independent proceedings would not be auspicious for either PDVSA or its creditors.

A final point on the Moratorium is that, perhaps, it may not even be available to PDVSA. Recall that in order to be eligible for a Moratorium proceeding, a debtor's assets in a liquidation must exceed its liabilities. Even if a Moratorium is initially recognized, the presiding judge could convert a Moratorium into a Bankruptcy proceeding at any point if there is any indication that the debtor's assets will be incapable of fully offsetting its liabilities. ${ }^{211}$ Given that all of PDVSA's publicly traded bonds are currently trading at a discount (the highest at 90.2, the lowest at 39.3), ${ }^{212}$ what would prevent a judge from converting a Moratorium to a Bankruptcy, or from outright dismissing a Moratorium petition?

convengan con el deudor, acuerden y aseguren el medio de atender al resultado de toda controversia con los disidentes, de modo que quede a éstos asegurada la parte que realmente pudieran sacar de la liquidación practicada prudentemente según sus respectivos derechos. Del convenio se pasará copia en todo caso al Tribunal, y si él ha obtenido el voto de la unanimidad de los acreedores, el Tribunal lo declarará así para que produzca todos sus efectos. Si sólo se reúne la mayoría indicada, el Tribunal decidirá en juicio verbal las disidencias, si ellas versan sobre algún derecho sostenido por el interesado respectivo y negado y dañado en el convenio, oída la comisión de acreedores; y de su decisión sólo se oirá apelación en un solo efecto y para ante el Tribunal Superior. Pero si no versan sobre los derechos disputados, el Tribunal se limitará a verificar la mayoría; y oída la comisión, aprobará el convenio."

210. For example, the Venezuelan State and its related public sector entities, such as the Venezuelan Central Bank, Venezuelan Economic and Social Development Bank, state-owned commercial banks, or other SOEs.

211. Código de Comercio [COMmercial Code] art. 907.

212. See Lucas Jullian, Grasping at Straws: Exploring PDVSA's Access to Debtor Relief Under Restructuring Regimes, 57 (June 25, 2017) (unpublished manuscript) (on file with the University of Pennsylvania Journal of Business Law) (discussing PDVSA bond trading patterns). 


\section{Venezuelan Legal System and Commercial Courts}

The second critical weakness of a potential Venezuelan insolvency proceeding is the current quality and performance of Venezuela's legal system. As perhaps expected from a court-supervised proceeding, Venezuelan commercial courts and their judges play a very active role in Moratoriums and Bankruptcies. Though not exhaustive, the following list enumerates the extensive powers and responsibilities of commercial courts in the context of a Moratorium:

(1) recognize or deny a debtor's petition of a Moratorium proceeding;

(2) establish duration of the Moratorium;

(3) establish the protective measures and precautions that it deems necessary to ensure the integrity of the debtor's assets;

(4) appoint creditors that will compose the creditor's committee, which will have oversight over the management and liquidation of the debtor's assets;

(5) "authorize the following acts: selling assets, granting securities, contracting debts, settling court cases, collecting or paying debts and other acts which are deemed necessary for the purposes of the liquidation",;

(6) recognize agreements between a debtor and its creditors if it counts with unanimous support from creditors;

(7) approve agreements between a debtor and its creditors if such an agreement is not unanimously backed by creditors, but counts with the support of creditors representing at least $75 \%$ of the debtor's liabilities;

(8) judge dissents against the plan; and

(9) decide whether to convert a Moratorium proceeding into a Bankruptcy proceeding at any time if (1) liabilities are discovered that the debtor had not initially disclosed, (2) if assets declared by the debtor are found to not exist, (3) if the debtor does not satisfy the obligations and conditions that were imposed upon it regarding the management and liquidation of its assets, (4) if the debtor is guilty of fraud or acting in bad faith, or (5) if the debtor's assets are insufficient to pay off its liabilities, or at least two thirds of them. ${ }^{214}$

213. Carlos Acedo Sucre and Luisa Acedo de Lepervanche, Venezuela: Insolvency Under Venezuelan Law, MondaQ, Apr. 11, 2005, referencing "Código DE ComerCio" [COMMERCIAL Code] art. 904.

214. Código de Comercio [Commercial Code] art. 898, 903, 906, 907, 911. 
In a Bankruptcy proceeding, the Court is granted even greater powers: as previously mentioned, the court takes possession of the debtor and appoints a trustee to liquidate its assets. ${ }^{215}$ Given this degree of involvement, the quality of Venezuelan commercial courts is a crucial element when evaluating a Venezuelan bankruptcy proceeding. The problem is, Venezuela's courts and legal system leave much to be desired judging by the assessments of international observers.

According to the World Justice Project, Venezuela ranks last in the Rule of Law Index, which analyzes the legal systems of 113 countries across multiple categories. ${ }^{216}$ Although Venezuela ranks last or close to last across all categories, it is noteworthy to highlight its ranking in categories that seem relevant in the context of a PDVSA proceeding. For example, Venezuela ranks last in Constraints on Government Powers, ${ }^{217}$ $103^{\text {rd }}$ on Absence of Corruption, last in Regulatory Enforcement, ${ }^{218}$ and $112^{\text {th }}$ in Civil Justice. ${ }^{219}$ Transparency International, for its part, ranks Venezuela $169^{\text {th }}$ of 180 in its 2017 Corruptions Perceptions Index..$^{220}$ Finally, the World Bank's Doing Business project ranks Venezuela $147^{\text {th }}$ of 190 in its Enforcing Contracts ranking, and places Venezuela among the 71 worst performing countries in its Quality of Judicial Processes index. ${ }^{221}$

Regarding insolvency proceedings in particular, Venezuelan judges tend to lack the experience, resources and infrastructure to manage

215. Id. art. 937, 939, 940 .

216. World Justice Project, Rule of Law Index: Venezuela, 2017-2018, http://data.worldjusticeproject.org/\#/groups/VEN (last visited March 06, 2018).

217. Considers if government powers are effectively limited by the (1) legislature, (2) judiciary, and/or (3) independent auditing and review. Also considers (4) if government officials are sanctioned for misconduct, (5) if government powers are subject to nongovernmental checks, and (6) if transition of power is subject to the law.

218. Measures if (1) government regulations are effectively enforced, (2) if government regulations are applied and enforced without improper influence, (3) administrative proceedings are conducted without unreasonable delay, (4) due process is respected in administrative proceedings, and (5) the government does not expropriate without lawful process and adequate compensation.

219. Measures if (1) people can access and afford civil justice; if (2) civil justice is free of discrimination, (3) free of corruption, (4) free of improper government influence, (5) is not subject to unreasonable delay, (6) is effectively enforced; and if (7) ADR is accessible, impartial, and effective.

220. Transperancy International, Corruption Perceptions Index 2016, (Feb. 15, 2018),

https://www.transparency.org/whatwedo/publication/corruption_perceptions_index_2017 (last visited March 6, 2018).

221. WORLD BANK, ENFORCING CONTRACTS, http://www.doingbusiness.org/data/exploretopics/enforcing-contracts. 
insolvency proceedings, leading to results that are "frequently disappointing for the Creditors and very damaging to the Debtor.,"222

With these assessments in mind, would a U.S. bankruptcy court recognize a Venezuelan foreign main proceeding involving an entity as important and close to the State and country of Venezuela as PDVSA? Could it reasonably believe that such a proceeding would be fair, involve due process, feature a "distribution" similar to the "order prescribed" by the U.S. Bankruptcy Code, and generally be in the interest of "creditors and other interested parties"? Since 2015, the U.S. Department of State has observed that "Venezuela's bankruptcy laws are outdated and inadequate to permit the reorganization of a debtor as a going concern." ${ }^{223}$ To what extent would a U.S. bankruptcy court agree or disagree with such an opinion?

Thus, a PDVSA foreign main proceeding under Venezuela's insolvency regime would not only have to deal with the issue of eligibility, but also with the deficiencies of Venezuela's insolvency statutes and legal system. As was the case of seeking relief under a plenary Chapter 11 proceeding, seeking relief under Chapter 15 would constitute a challenging and contentious endeavor.

\section{OTHER ALTERNATIVES}

Although a U.S. Chapter 11 proceeding or a Venezuelan foreign main proceeding (coupled with Chapter 15 recognition) seemed to be the most appropriate venues by which PDVSA could seek debtor relief, they are unfortunately fraught with considerable legal obstacles. Even if those challenges could be ultimately overcome, they could nonetheless incite legal challenges to be presented by creditors opposed to or seeking leverage over PDVSA.

The difficulties and contentious elements of both options thus invites the question: are there any other alternatives that would allow PDVSA to circumvent these issues? Could anything be modified so as to allow PDVSA access to debtor relief, either under American, Venezuelan, or other restructuring regimes? As an exercise of contemplating different alternatives, three other cases will be briefly considered:

(1) Foreign Non-Main Proceeding \& Ancillary Chapter 15 Recognition,

222. Acedo Sucre and Acedo de Lepervanche, supra note 213.

223. U.S. Department of State, supra note 194. 
(2) Venezuelan Foreign Main Proceeding \& Ancillary Chapter 15 Recognition, After Modifying PDVSA Legal Regime and Venezuelan Insolvency Regime, and

(3) the Amendment of Governing Law \& Jurisdiction of U.S. Liabilities.

\section{A. Foreign Non-Main Proceeding \& Ancillary Chapter 15 Recognition}

What if PDVSA, rather than seeking Chapter 15 recognition of a Venezuelan proceeding, instead sought recognition of a foreign non-main proceeding under another restructuring regime and jurisdiction more palatable to U.S. courts? Would such a strategy provide PDVSA with a better chance of recognition and relief in the United States?

While such a course of action may avoid problems stemming from Venezuela's insolvency regime and legal system, it unfortunately would do nothing to address the issue of eligibility. Changing the regime and jurisdiction of a PDVSA proceeding would not alter PDVSA's relationship with the Venezuelan State, and therefore would not improve PDVSA's ability to comply with 11 U.S.C $\$ 109$ (a). Thus, this strategy is unlikely to be an effective alternative to a plenary Chapter 11 proceeding or a Venezuelan foreign main proceeding recognized under an ancillary Chapter 15 filing.

\section{B. Venezuelan Foreign Main Proceeding \& Ancillary Chapter 15 Recognition, After Modifying PDVSA Legal Regime and Venezuelan Insolvency Regime}

As mentioned in the previous case, PDVSA may be unable to seek relief in the United States under any kind of proceeding, initiated anywhere in the world, if it does not comply with the definition of "person" in the U.S. Bankruptcy Code. Thus, could Venezuela alter its relationship with PDVSA in order to comply with $\S 109$ (a) of the U.S. Bankruptcy Code? Furthermore, what if Venezuela modified its insolvency regime so as to satisfy U.S. courts' expectations of a foreign proceeding meriting recognition and relief?

Considering the numerous actions that would have to be undertaken by Venezuela and the very generous assumptions on the granting of comity by U.S. courts, it would be fair to characterize this path as an academic exercise. At a minimum, such a scenario would require: 
(1) the passing of legitimate reforms to Venezuela's laws, including the Venezuelan Constitution, Commercial Code, Organic Law of Hydrocarbons, and PDVSA's Articles of Incorporation and Corporate Statutes; $; 24$

(2) evidence suggesting that PDVSA's management and day-to-day operations are not directed by the Venezuelan State (thus distancing PDVSA from the influence of the executive branch);

(3) guarantees or other indications that would allow a U.S. court to confidently believe that a proceeding under a new Venezuelan insolvency regime would be fair and in good faith; and

(4) a proceeding in which either (a) the absolute priority rule is not egregiously violated (implying Venezuela would not be guaranteed an interest in PDVSA while dissenting creditors remained impaired) or (b) a U.S. court willing to provide relief despite a violation of the absolute priority rule (which would be the case if the Venezuelan State were guaranteed any interest in a restructured PDVSA despite the dissent of impaired creditor classes).

These are, of course, significant and complex departures from current circumstances. For the sake of argument, however, it should be noted that Venezuela's legal regime has historically been quite malleable. Since its independence, Venezuela has had twenty-six constitutions - and may be in the process of developing yet another (despite political opposition). ${ }^{225}$ Additionally, although PDVSA has been wholly owned by the Venezuelan State since its incorporation, its relationship to the Venezuelan State has not always been as "symbio[tic]" 226 as it has been since 2003. ${ }^{227}$ These observations are not meant to minimize the highly unlikely nature of this

224. Clearly a challenge given the current state of politics and conflict between branches of government. See Jose Orozco and Fabiola Zerpa, Venezuela Opposition Calls New Protests as Death Toll Mounts, BLOOMBERG, April 24, 2017, https://www.bloomberg.com/news/articles/2017-04-25/venezuela-s-opposition-calls-newprotest-as-death-toll-mounts (discussing the reinvigorated plans of Venezuela's opposition party)

225. Nathan Crooks and Fabiola Zerpa, Why Venezuela May Change It's Constitution for the 27th Time, BLOOMBERG, May 9, 2017, https://www.bloomberg.com/politics/articles/2017-05-09/why-venezuela-may-get-its-27thconstitution-quicktake-q-a.

226. Moody's Investors Service, Petroleos de Venezuela, S.A.: Credit Opinion, pg. 1.

227. Bernard Mommer, Petróleo Subversivo, in La Política Venezolana en la Época de Chávez: Clases, Polarización y Conflicto, 167-185 (Steve Ellner and Daniel Hellinger ed., Serra Rojas and Marireyna trans, 2003); see Venezuela's oil diaspora: Brain haemorrhage, THE ECONOMIST, July 19, 2014, http://www.economist.com/news/americas/21607824-venezuelas-loss-thousands-oilworkers-has-been-other-countries-gain-brain-haemorrhage," (arguing that PDVSA has not always had a harmonious relationship with the Venezeulan State). 
scenario, but rather to note that it may yet pertain to the realm of the possible.

\section{Amend Governing Law \& Jurisdiction of U.S. Liabilities}

Given the extraordinary measures Venezuela and PDVSA would have to undertake to unquestionably assuage U.S. statutes and courts - is there any alternative by which PDVSA could circumvent the need for U.S. recognition altogether? For example, could this be achieved by amending the governing law and jurisdiction provisions of its U.S liabilities ${ }^{228}$ to a legal system whose statutes, courts, and restructuring regime are more amenable to an entity in PDVSA's circumstances? It may be worthwhile to consider such a scenario under English law and making use of the English scheme of arrangement (scheme) to restructure PDVSA's liabilities.

The reasons to contemplate such an alternative are threefold. First, the English scheme is comparable in sophistication and effectiveness to the U.S. Bankruptcy Code's Chapter 11. Though different in substantial aspects, they are both considered the "most attractive forums in which to promulgate the restructuring of a multinational corporate group." ${ }^{229}$ Unlike Chapter 11, a scheme is "not necessarily an insolvency procedure, ${ }^{, 230}$ and does not provide debtors with an equally expansive set of tools or relief. ${ }^{231}$ It does, however, provide a cramdown mechanism ${ }^{232}$ and, crucially for PDVSA, greater flexibility when it comes to debtor eligibility. In order to be eligible to make use of a scheme, a debtor needs only to establish a "sufficient connection" with England. ${ }^{233}$ In In Re Rodenstock $G m b H$, the presiding English court found that a "sufficient connection" was constituted by the choice of English law in a credit document's governing law provision. ${ }^{234}$ Thus, if PDVSA's liabilities were governed by English law, they could potentially be restructured under a scheme.

This leads us to the second point of this scenario: there is already precedent for a firm amending the governing law and jurisdiction provisions of its liabilities from New York law to English law for the explicit purpose of restructuring them under a scheme. In 2015, DTEK Finance BV (a Dutch subsidiary of a Ukrainian power company)

228. For example, its U.S. dollar-denominated secured and unsecured bonds.

229. Zacaroli QC and Riddiford, supra note 119, at 6.

230. Id. at 6-7.

231. Id. at 6 .

232. A scheme is deemed to be approved when creditors representing at least $75 \%$ of claims in value, and at least $50 \%$ in number in each class participating in the scheme vote favorably.

233. [2011]EWHC (Ch) 110468 (U.K.).

234. Id. 
restructured its senior notes governed by New York law by amending its governing law and jurisdiction, and subsequently executing a scheme. ${ }^{235}$ Because the notes did not explicitly specify the majority required to change the notes' governing law and jurisdiction provisions, DTEK's legal counsel argued that a simple majority would suffice to change them. This was further supported by former Judge James M. Peck, ${ }^{236}$ who provided expert evidence to the English court presiding over the scheme. ${ }^{237}$ PDVSA's notes, likewise, do not explicitly state the kind of majority required to amend their governing law and jurisdiction provisions. The English court, for its part, found that "the change of governing law to English law should be treated as a sufficient connection with this court.",238

Critically, by changing the law and jurisdiction governing the notes away from New York law, it seems DTEK avoided the need to initiate a U.S. proceeding altogether. For a point of comparison, consider what transpired when DTEK carried out a different scheme in 2016 (the "LTR Scheme"), modifying - among other liabilities - senior notes governed by New York law. This time around, DTEK did pursue Chapter 15 recognition of the scheme. According to DTEK's legal counsel, the filing of an ancillary Chapter 15 case was instigated by the fact that a New York law-governed instrument was being affected by a scheme. Per the legal counsel: "as [the notes] were governed by New York law, DTEK also filed a petition for the recognition of the LTR Scheme sanction order under Chapter 15 of the US Bankruptcy Code. ${ }^{239}$ Thus, considering what transpired in each of these two schemes, it seems that as long as PDVSA does not affect New York law-governed liabilities by a scheme, it may perhaps be able to avoid seeking recognition in the United States.

The third reason to consider such a scenario is that, in important contrast to eligibility under U.S. proceedings, it seems that PDVSA's status as an SOE may not be an impediment for being able to restructure its liabilities via a scheme. In 2013, the Vietnamese Shipbuilding Industry Group (Vinashin), ${ }^{240}$ a SOE wholly owned by the Government of Vietnam,

235. John Houghton, David Stewart and Vanessa Morrison, The DTEK Scheme: A New Way to Restructure US Law Bonds, LAtham Watkins Client Alert Commentary, (May 5, 2015), https://www.lw.com/thoughtLeadership/lw-the-dtek-scheme.

236. Former United States Bankruptcy Judge in the Southern District of New York.

237. Houghton, Stewart and Morrison, supra note 235.

238. In the Matter of DTEK Finance B.V., [2015] EWHC (Ch) 116416 (U.K.).

239. John Houghton, Margaret S. Fong and Vanessa Morrison, The DTEK Restructuring

- The Final Chapter, Latham Watkins Client Alert Commentary, April 27, 2017. https://www.lw.com/thoughtLeadership/DTEK-restructuring-final-chapter.

240. As part of the Vietnamese government's efforts to restructure Vinashin, Vietnam's Ministry of Transport created the Shipbuilding Industry Corporation (SBIC) to take charge of the restructuring of Vinashin and its companies. SBIC will continue the rights, legal obligations, and interest of Vinashin. SBIC was founded as a Single Member Limited 
successfully made use of the scheme to restructure and bind all creditors of a US\$600 million facility governed by English law. ${ }^{241}$ Considering PDVSA's potential use of a scheme, there are a few notable elements of this case that should be highlighted. First, the nature of Vinashin's relationship with the Vietnamese State seems to have played no role in the analysis carried out by the court when sanctioning Vinashin's scheme. ${ }^{242}$ Second, Vinashin's legal and financial advisors expressed that Vinashin's decision to restructure the facility under a scheme was partially motivated by the comparable unattractiveness of Vietnam's bankruptcy laws. ${ }^{243}$ Third, even though Vinashin had no assets or operations in the United Kingdom, and that none of its creditors were in England, ${ }^{244}$ the court was of the "view that the fact that the loan agreement is governed by English law is of itself sufficient to create that necessary connection." "245 Fourth, although a scheme proceeding does not provide an automatic stay against creditor litigation, the court did provide a stay against two lenders seeking repayment of outstanding principal and interest due on the US\$600 million facility. $^{246}$

Liability Company whose 100 percent stake is held by the government and is under the direct management of the Ministry of Transport, and the Minister of Transport is fully authorized to assign its chief officials. See Establishment of the Shipbuilding Industry, SHIPBUILDING INDUSTRY CORPORATION (Oct. 31, 2013), http://sbic.com.vn/News/Establishment-of-theShipbuilding-Industry-Corporation-SBIC.html?p=158\&id=1570 (discussing the ownership structure of the Shipbuilding Industry Corporation).

241. When Vinashin defaulted on its debts, it had total liabilities of US $\$ 4.6$ billion. See Jonathan Leitch, Vietnamese Restructuring Using an English Scheme of Arrangement, DLA PIPER PUBLICATIONS (Dec. 12, https://www.dlapiper.com/en/uk/insights/publications/2013/12/vietnamese-restructuringusing-an-english-scheme__ (discussing whether English Courts had jurisdiction to wind up Vinashin).

242. Re Vietnam Shipbuilding Industry Group, [2013] EWHC (Ch) 2476 (U.K.).

243. Leitch, supra note 241; Devi Shah and Jessica Walker, First Scheme of Arrangement for a Vietnamese Company is Sanctioned, MAYER Brown Legal Update (Sept. 5, 2013), https://www.mayerbrown.com/First-Scheme-of-Arrangement-for-a-Vietnamese-Companyis-Sanctioned-09-05-2013/; and Phil Smith, Ha Do and Eddie Middleton, Vinashin Stays Afloat-Ground Breaking English Scheme Approved for a Vietnamese Restructuring, KPMG RESTRUCTURING NEWSLETTER (Oct. 4, 2013), https://home.kpmg.com/cn/en/home/insights/2013/09/restructuring-newsletter-1309-

03.html. Vietnam's insolvency regime was ranked $125^{\text {th }}$ in the World Bank's Doing Business Resolving Insolvency ranking. In contrast, the United Kingdom's insolvency regimes are ranked $13^{\text {th }}$ and Venezuela's $165^{\text {th }}$. THE WORLD BANK, Resolving Insolvency, DOING BUSINESS (June 2017), http://www.doingbusiness.org/data/exploretopics/resolving-insolvency (Accessed March 6, 2018) (showing ).

244. Shah and Walker, , supra note 243.

245. Re Vietnam Shipbuilding Industry Group, at 9 (discussing the facts and benefits of Vinashin utilizing an English scheme of arrangement).

246. Tom Smith, Moratoriums and Schemes of Arrangement, SOUTH SQUARE DigEST (August 2013), http://www.southsquare.com/files/SSD-issue-20-Aug-13.pdf; see Shah and 
Although this restructuring alternative seems promising as a path by which to address obstacles posed by U.S. statutes and courts to a PDVSA proceeding, it is not without its own set of challenges or potentially litigious elements. First, it is unclear whether the governing law and jurisdiction provisions of a New York law-governed contract could be amended by a simple majority, or if it would require a higher threshold of participation. When DTEK pursued its first scheme, it was challenged by Alden Global Capital (a hedge fund investing in DTEK's notes), which argued that "the change of governing law needed more than $90 \%$ consent because it would impair the rights of creditors to bring enforcement proceedings." ${ }^{247}$ The court, however, never had to provide an opinion on this matter, as DTEK's scheme ultimately received the approval of $91.1 \%$ of its noteholders, leading Alden Global Capital to withdraw the challenge. ${ }^{248}$ Beyond the matter of the specific threshold to be overcome, it seems that this may be a point for litigation.

A second issue is that, if PDVSA sought to restructure its New York law-governed liabilities in a single scheme without recognition in U.S. courts, it would first have to amend those liabilities individually, gaining sufficient creditor consent to amend them on a series by series basis. This means that if dissenting creditors wished to prevent their security from being restructured under a scheme in this context, they could do so by acquiring the minimum participation necessary to block an amendment to the governing law and jurisdiction provisions. As mentioned in the previous point, it is unclear whether such a minimum stake would be $10 \%$ or $50 \%$ of an issuance.

A third issue is that, even if PDVSA may not have to or may not wish to seek recognition of a scheme in the United States via an ancillary Chapter 15 case, it may nonetheless have to prove that a scheme would be enforceable in the United States. Even though DTEK did not petition Chapter 15 recognition of its first scheme, the English court presiding the scheme proceeding noted that:

[C]ourts have ... always needed assurance that the Scheme will have a practical effect... so far as the New York courts are concerned, the legal advice received by DTEK is that relief to prevent actions in conflict with the terms of the approved Scheme will be readily obtainable either as a matter of comity or because it is DTEK's intention to register the Scheme under Chapter 15 of

Walker, supra note 243 (discussing English Courts jurisdiction to stay actions brought against a debtor).

247. Tom Young, DTEK Shifts High-Yield Restructuring Options, InTERnATIONAL FinANCIAL LAw REVIEw (May 20, 2015), https://www.lw.com/mediaCoverage/dtekrestructuring.

248. Id. 
the US Bankruptcy Code. ${ }^{249}$

In fact, when DTEK sought to counter challenges to its scheme with expert evidence from Judge Peck, part of DTEK's argument relied on "extensive precedents ... that a US federal court or New York state court would: (a) extend comity to the judgement approving the Scheme; and (b) grant Chapter 15 recognition of the Scheme based on DTEK's COMI . . . in England. ${ }^{, 250}$ In an article reviewing DTEK's first scheme, Linklaters observed that "increasing the probability that a US court would both recognize and afford injunctive and other relief in support of a UK scheme ... is also likely to assist the English court in exercising its discretion whether to take jurisdiction or sanction a scheme in the first instance." ${ }^{251}$ Linklaters goes on to highlight a case when a debtor sought to explicitly rule out the need for Chapter 15 recognition:

[A]t the convening hearing for the Zlomrex scheme ... Mann J expressed 'misgivings' about the inclusion of wording in the scheme which enabled the company ... to waive a condition to implementation of the scheme that it seek Chapter 15 recognition. Although he did not insist on its removal and duly convened the relevant creditor meetings, his concern was that the English court might give 'the impression of blithely overriding New York law rights and any legitimate interests of the New York court. ${ }^{252}$

Thus, even if PDVSA does not seek recognition of a scheme in the United States, would it have to prove to an English court that such a scheme would be granted comity under Chapter 15 of the U.S. Bankruptcy Code? If PDVSA were forced to do so - despite carrying out a scheme that only sought to restructure liabilities amended to be governed by English law - then PDVSA once again may be unable to escape the challenges of seeking recognition from U.S. courts under the U.S.

Bankruptcy Code. And this, of course, is prior to any other issue that may be raised by English judges when evaluating an attempt by PDVSA to make use of English law and courts.

It is important to note that if PDVSA sought to change the governing law and jurisdiction provisions of its U.S. liabilities, it could propose to change them to those of any other state or country on the planet. Ultimately, amending these provisions relies on receiving sufficient support from creditors - creditors which, in turn, would likely seek sufficient

249. In the Matter of DTEK Finance, EWHC (Ch) 1164 at 19.

250. Houghton, Stewart, and Morrison, supra note 235, at 3.

251. Linklaters, DTEK Exchange Offer and Scheme of Arrangement: Faciitating HighYield Debt Restructurings, LinKLATERS 3 (May 2015), file:///Users/aday/Downloads/Combined_DTEK_alert.pdf 252. Id. 
confidence and comfort in the governing law and jurisdictions proposed. English law has been used as an example in this particular case due to the proven sophistication, robustness, and flexibility of its restructuring regime. Although PDVSA would not be confined to English law if it pursued this strategy, it would still need to propose a law and jurisdiction acceptable to creditors.

\section{CONCLUSION}

PDVSA and its sole shareholder, the Bolivarian Republic of Venezuela, are currently facing daunting levels of financial and economic distress. As reflected by the prices of their publicly traded bonds, their seemingly dire circumstances have incited speculation on their ability to service their obligations, prompting scholars, credit-rating agencies, and capital market participants to ponder the likelihood, manner, and implications of their potential defaults. An element of this discussion is whether PDVSA may be able to restructure its liabilities by utilizing debtor relief mechanisms from pertinent restructuring regimes.

An assessment of PDVSA's assets, operations, and liabilities signals that the most apparent restructuring strategies contemplating debtor relief would, in order to be effective, require recognition from U.S. courts. Unfortunately, PDVSA's relationship with the Venezuelan State, along with the condition of Venezuela's legal system, present extraordinary challenges for PDVSA's access to or recognition of debtor relief in the United States. The pursuit of any strategy requiring the actual or hypothetical satisfaction of U.S. statutes and courts would thus likely be contentious, eliciting legal reactions from dissenting creditors. Alternative strategies - such as changing PDVSA's relationship to the state or amending its liabilities so as to avoid U.S. courts - may fail to prove any less litigious, impractical, or inviable. And this is without even taking into account sanctions and other public policy instruments that additionally complicate or hinder PDVSA's access to restructuring alternatives.

Even if the strategies contemplated in this paper were ultimately legally available to PDVSA, they would still require considerable levels of creditor consent in order to be successful. ${ }^{253}$ This may raise a question of

253. Under a plenary U.S Chapter 11 proceeding, PDVSA would require the support of creditors representing at least two-thirds of claims in amount, and more than one half in number across all impaired classes (this assumes Venezuela would seek to maintain its equity interest in PDVSA and thus, per the absolute priority rule, would not be able to cram a plan on dissenting impaired creditors). Under a Venezuelan Moratorium, PDVSA would require the support of creditors representing 75\% of claims in value across all of PDVSA's liabilities. Under an English scheme of arrangement, PDVSA would require the support of creditors representing $75 \%$ of claims in amount, and $50 \%$ in number in each class affected by the 
whether pursuing formal debtor relief (e.g. stay on creditor litigation or cramdown provision) would be worth the trouble. Given the high levels of creditor support required to effectively use any of the alternatives explored, could PDVSA not simply avoid default via voluntary mechanisms supported by the same kind of percentage of creditors that would otherwise be required of court-sanctioned restructuring regimes?

If the unremarkable outcome of PDVSA's 2016 voluntary bond swap is any indication, it would be reasonable to be skeptical about the feasibility of averting default on completely voluntary agreements. Considering the terms offered and threats extended by PDVSA to its creditors, the 2016 bond swap exemplified PDVSA's creditors' ability to tolerate risk, ${ }^{254}$ overlook incentives, and remain unmoved by the prospect of default. ${ }^{255}$

proposed scheme.

254. Steve Johnson, Venezuela Investors Undeterred by Near-Certain Default, FINANCIAL TiMES (June 1, 2017), https://www.ft.com/content/0231dfca-4553-11e7-8519-9f94ee97d996.

255. For PDVSA's announcements on the 2016 bond swap, see Petróleos de Venezuela, S.A., Anuncio de Prensa, (September 16, 2016), http://www.pdvsa.com/templates/pdvsa/img/bonos/bonopdvsa2017/Anuncio\%20de\%20Pren sa\%20(PDF).PDF (Accessed May 4, 2017); Petróleos de Venezuela, S.A., Extensión de la Fecha de Vencimiento Temprana, (October 6, 2016), http://www.pdvsa.com/images/pdf/bonos/extensiondelafechadevencimientotemprana.pdf (Accessed June 14, 2017); Petróleos de Venezuela, S.A., 2da. Extensión de la Fecha de Vencimiento Temprana, (October 12, http://www.pdvsa.com/images/pdf/bonos/2daextensiondelafechadevencimienotemprana.pdf (Accesssed June 14, 2017); Petróleos de Venezuela, S.A., 3era. Extensión de la Fecha de Vencimiento Temprana, (October 17, http://www.pdvsa.com/images/pdf/bonos/3raextensiondelafechadevencimientotemprana.pdf (Accessed June 14, 2017); Petróleos de Venezuela, S.A., Final Announcements, (October 24, 2016)

http://www.pdvsa.com/templates/pdvsa/img/bonos/bonopdvsa2017/Final\%20announcement s\%20(PDF).PDF (Accessed June 14, 2017). For media coverage of the swap and its outcome, see Eric Platt and Jessica Dye, Venezuela's State-Owned Oil Group Debt Swap Flounders, FinANCIAL TIMES (October 10, 2016), https://www.ft.com/content/e9e18bac-8caa-11e6-8aa5f79f5696c731?mhq5j=e1; Robin Wigglesworth and Andres Schipani, Venezuelan Oil Major's Debt Swap: The Beginning of the End, Financial Times (September 26, 2016), https://www.ft.com/content/aadf657c-7f4a-11e6-8e50-8ec15fb462f4?mhq5j=e1; Eric Platt and Robin Wigglesworth, Venezuela's PDVSA Raises Stakes in Bond Swap, FinAnCIAL TimeS (October 18,2006), https://www.ft.com/content/10eca952-9548-11e6-a1dc-bdf38d484582; Jonathan Wheatley and Eric Platt, What Now for Venezuela's PDVSA After the Bond Swap, FinANCIAL TiMES (October 25, 2016), https:/www.ft.com/content/e5298570-9a96-11e68f9b-70e3cabccfae?mhq5j=e1; Christine Jenkins and Ben Bartenstein, PDVSA Debt Swap Plan Gets Early Thumbs Down From Investors, BLOOMBERG (September 19, 2016, 8:33AM), https://www.bloomberg.com/news/articles/2016-09-19/pdvsa-debt-swap-proposal-getsearly-thumbs-down-from-investors; Sebastian Boyd and Nathan Crooks, Venezuela's PDVSA Sows Payment Doubts While Extending Swap, BLOOMBERG (October 17, 2016, 11:14PM), https:/www.bloomberg.com/news/articles/2016-10-18/venezuela-extends-bond-swapdeadline-for-third-time-to-oct-21; Johanna Bennett, Venezuela Oilco PDVSA: Bond Swap Buys Time, BARRON's (October 26, 2016, 12:45PM), 
Voluntary exchanges, however, may nonetheless remain the only clear, uncontestable mechanism by which to restructure PDVSA's debts. Unfortunately, even voluntary exchanges are temporarily impracticable, as U.S. sanctions in force as of the writing of this paper prohibit U.S. persons from partaking in such a transaction. ${ }^{256}$

Thus, those interested in, affected by, or wagering on PDVSA's financial future, would do well to prioritize preparing for out-of-court voluntary negotiations on one hand, and understand the implications of default on the other. There are, of course, scenarios in which PDVSA may avoid becoming insolvent or requiring debtor relief. ${ }^{257}$ Though stakeholders may hope for the best, they should also be prepared for the worst: PDSVA's potential incapability, or unwillingness, to pay for its obligations.

Beyond PDVSA's specific predicament, the issues touched upon in this paper may also provide some lessons for other SOEs or quasisovereign entities contemplating the issuance of debt in the capital markets. Given the potential difficulties stemming from the U.S Bankruptcy Code's provisions on eligibility and recognition, and the expansive powers of U.S. courts to dismiss cases or limit relief, SOEs should consider issuing debt governed by the laws of jurisdictions more amenable to state-owned or quasi-sovereign entities. Alternatively, such issuers may wish to consider including more flexible amendment provisions in their future indentures, such as Collective Action Clauses (CACs.) ${ }^{258}$ Planning for default may understandably not be at the top of mind of issuers or their sovereign

http://www.barrons.com/articles/venezuelas-pdvsa-bond-swap-buys-it-time-to-muddlethrough-1477413923; and Mark Walker and Jill Dauchy, Restructuring Venezuelan Debt, The CLS BLUE SKY BLOG (November 14, 2016), http://clsbluesky.law.columbia.edu/2016/11/14/restructuring-venezuelan-debt/.

256. Exec. Order No. 13808, 82 Fed. Reg. 41,115 (August 24, 2017).

257. Perhaps increases in oil price or other improvements in operations would allow it to meet its obligations. Perhaps it could effectively continue defraying obligations via voluntary exchanges or other forms of liability-management transactions. (See Brian Ellsworth, Corina Pons, and Marianna Parraga, Venezuela's PDVSA Quietly Issues New Debt to Pay Off Suppliers, REUTERS (May 3, 2017), http://www.reuters.com/article/us-venezuela-economyexclusive-idUSKCNOXU1HL (discussing various securities offerings made by PDVSA). Perhaps it could generate liquidity by selling interests in its subsidiaries or other assets. Perhaps it could receive necessary capital infusions from the government. Perhaps it could raise resources via other sources or forms of financing which may present better/more amenable/pose lesser risks to interruption of its business than publicly traded securities issued and traded in international capital markets.

258. For example, some of the Notes issued by Petróleos Mexicanos (PEMEX), Mexico's state owned oil company, incorporate CACs reminiscent of those found in instruments issued by sovereign issuers. Se Petróleos Mexicanos, Final Prospectus, Petróleos Mexicanos, Exchange Offer, PEMEX 50 (Feb. 22, http://www.pemex.com/ri/reguladores/Documents/Rule\%20424(b)(3),\%20filed\%20Feb22, \%202018.pdf (listing the securities offerings of Petroleos Mexicanos)). 
owners when issuing debt. However, the worst moment to learn of one's inability to access debtor relief would be, undeniably, in circumstances in which it is most needed. 


\section{Appendix}

\section{Appendix 1: PDVSA \& Venezuela Long Term Rating History}

Figure 4: PDVSA Long Term Rating History, Moody's ${ }^{259}$

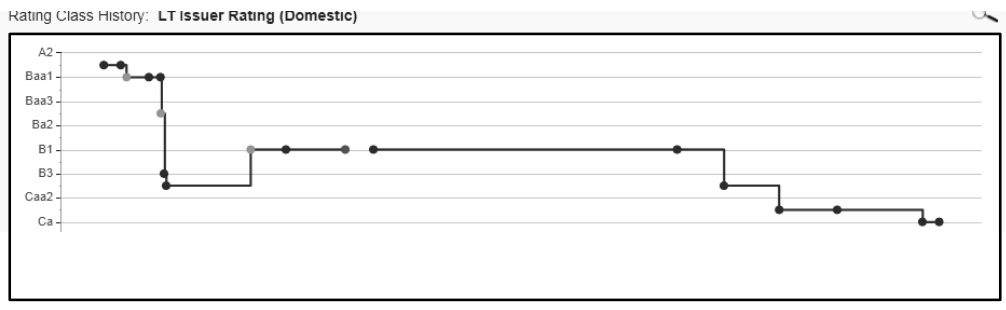

Figure 5: Venezuela Long Term Rating History, Moody's ${ }^{260}$

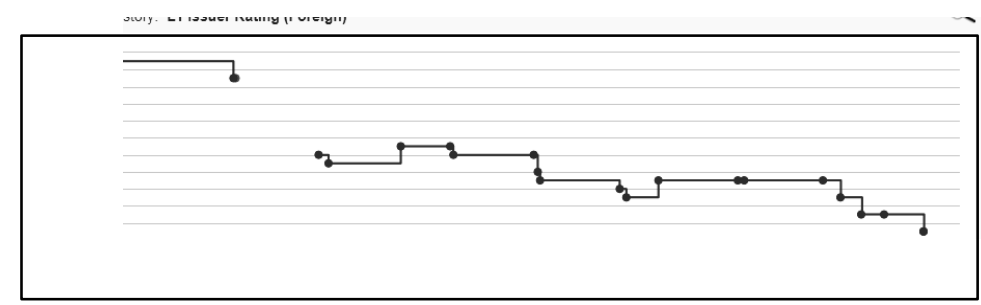

259. Moody's Investors Service, Petroleos de Venezuela, S.A.: Rating.

260. Moody's Investors Service, Venezuela, Government of: Ratings 


\section{Appendix 2: PDVSA \& Venezuela Bond Pricing}

Figure 6: PDVSA Bond Pricing, October 6, 2015-March 6, $2018^{261}$

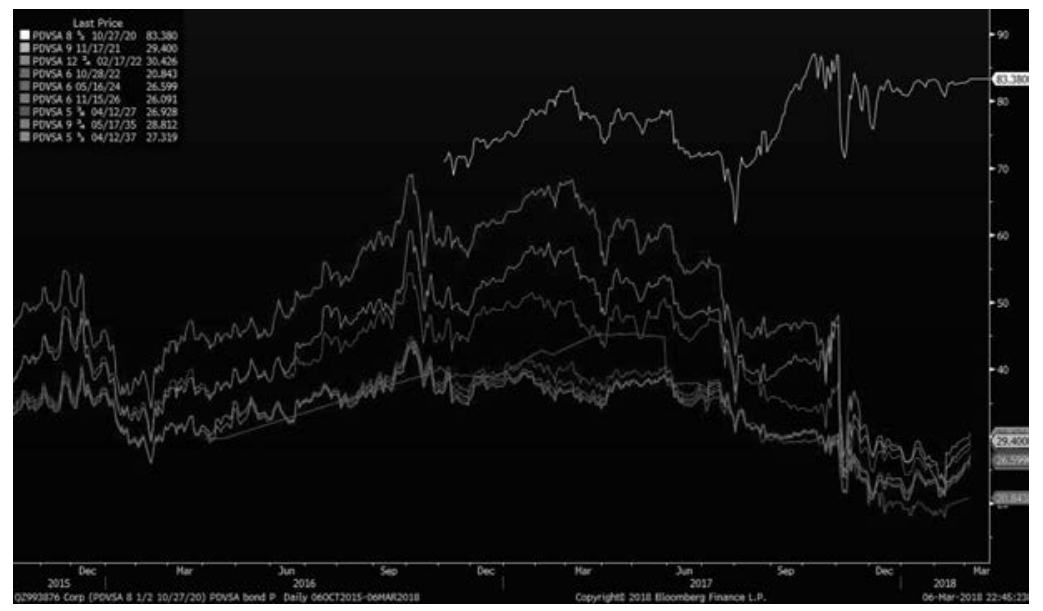

Figure 7: Venezuela Bond Pricing, October 6 2015-March 6, $2018^{262}$

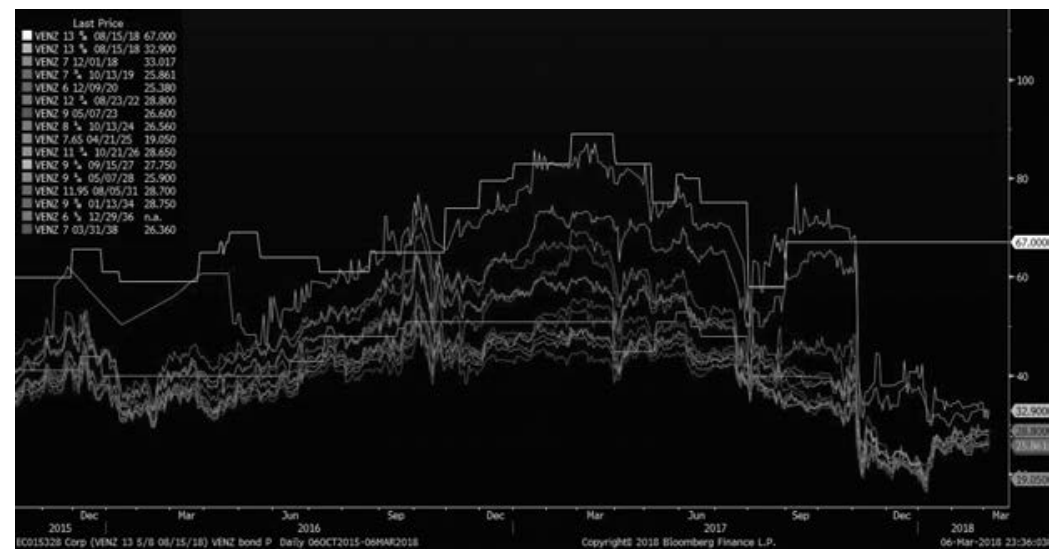

261. Bloomberg Finance L.P., "Bond price graph for PDVSA."

262. Bloomberg Finance L.P., "Bond price graph for Venezuela." 


\section{Appendix 3: PDVSA \& Venezuela Bond Yields (Mid Price}

\section{YTM)}

Figure 8: PDVSA Bond Yields (Mid Price YTM), October 6, 2015-

$$
\text { March 6, } 2018^{263}
$$

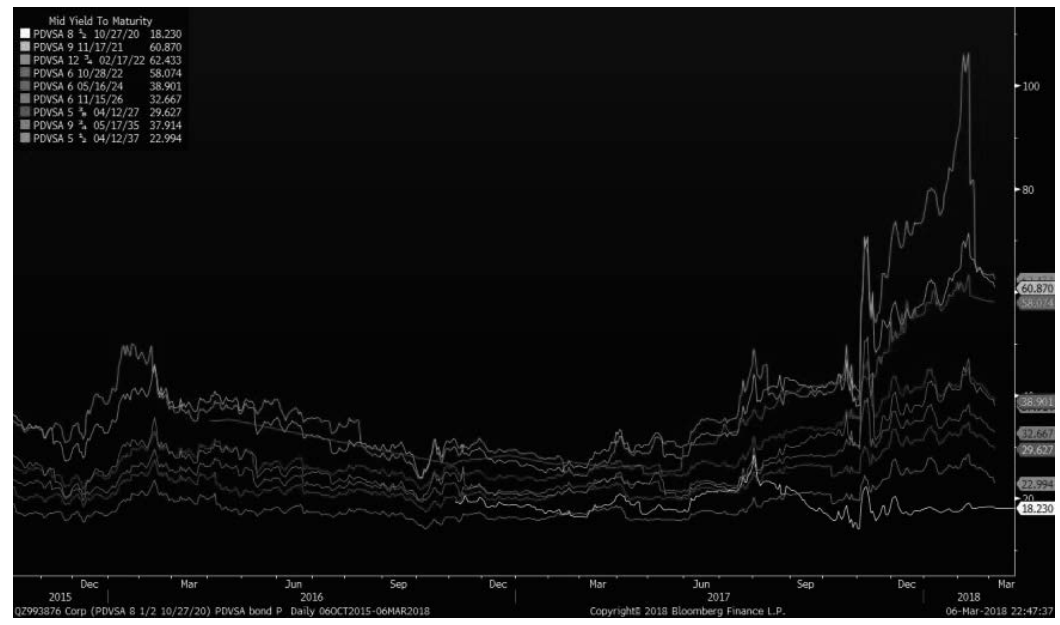

Figure 9: Venezuela Bond Yields (Mid Price YTM), October 6, $2015-$

$$
\text { March 6, } 2018^{264}
$$

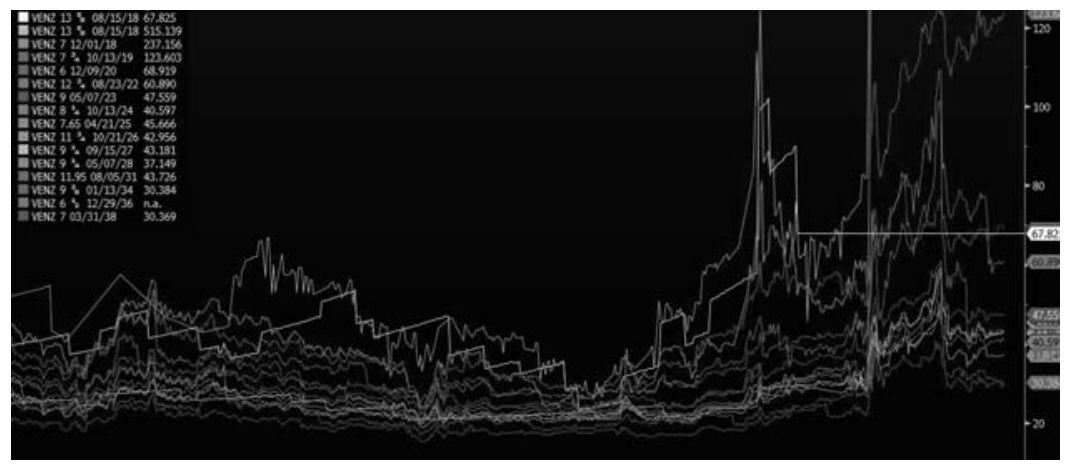

263. Bloomberg Finance L.P., "Bond yield (Mid price YTM) graph for PDVSA."

264. Bloomberg Finance L.P., "Bond yield (Mid price YTM) graph for Venezuela." 


\section{Appendix 4: PDVSA's Financial Debt and Other Liabilities}

Table 4: PDVSA's Financial Debt and Other Liabilities

\begin{tabular}{|c|c|c|c|c|}
\hline Liabilities & Currency & $\begin{array}{l}\text { Outstanding } \\
\text { uSs million }\end{array}$ & $\begin{array}{c}\text { Interest } \\
\text { Rate }\end{array}$ & $\begin{array}{c}\text { Information } \\
\text { Source }\end{array}$ \\
\hline$\$ 450 \mathrm{~m}$ Secured $\mathrm{A} / \mathrm{R}$ Facility & USD & 225 & $\mathrm{CP}+1.50 \%$ & PDVSA 2016 Financial Statements \\
\hline$\$ 900 \mathrm{~m}$ Secured Revolving Credit Facility & USD & 50 & Base Rate $3.5 \%+1.75 \%$ & PDVSA 2016 Financial Statements \\
\hline$\$ 650 \mathrm{~m}$ Senior Secured Term Loan B & USD & 635 & LBBOR $1.00 \%$ floor $+3.50 \%$ & PDVSA 2016 Financial Statements \\
\hline $6.250 \%$ Senior Secured Notes due $08 / 15 / 22$ & USD & 650 & $6.250 \%$ & PDVSA 2016 Financial Statements \\
\hline $4.880 \%$ Industrial tax exempt bond due $05 / 01 / 25$ & USD & 50 & $4.880 \%$ & PDVSA 2016 Financial Statements \\
\hline $8.000 \%$ Industrial tax exempt bond due $04 / 01 / 28$ & USD & 25 & $8.000 \%$ & PDVSA 2016 Financial Statements \\
\hline $8.000 \%$ Industrial tax exempt bond due $06 / 01 / 32$ & USD & 30 & $8.000 \%$ & PDVSA 2016 Financial Statements \\
\hline $\begin{array}{l}\text { Capital Leases of CITGO Petroleum Corp. } \\
\text { CITGO Petroleum Corp Secured Debt }\end{array}$ & USD & $\begin{array}{r}507 \\
2,172\end{array}$ & & PDVSA 2016 Financial Statements \\
\hline $6.000 \%$ Industrial tax exempt bond due $07 / 01 / 23$ & USD & 3 & $6.000 \%$ & PDVSA 2016 Financial Statements \\
\hline CTTGO Petroleum Corp Unsecured Debt & & 3 & & \\
\hline \begin{tabular}{|l|} 
CITGO Petroleum Corp. Total Debt \\
\end{tabular} & & 2,175 & & \\
\hline$\$ 1,300 \mathrm{~m}$ Senior Secured Tem Loan B & USD & 652 & LIBOR $1.00 \%$ floor $+8.50 \%$ & PDVSA 2016 Financial Statements \\
\hline 10.750\% Senior Secured Notes due 02/15/20 & USD & 1,500 & $10.750 \%$ & PDVSA 2016 Financial Statements \\
\hline CTTGO Holding Inc. Secured Debt & & 2,152 & & \\
\hline \begin{tabular}{|l|l|} 
CTTGO Holding Inc. \& Subsidiaries Total Debt \\
\end{tabular} & & 4,327 & & \\
\hline Petrolera Cerro Negro, S.A. - 7.900\% Guaranteed Bonds due 06/30/20 & USD & 1 & $7.900 \%$ & PDVSA 2016 Financial Statements \\
\hline$\$ 2,206 \mathrm{~m}$ Credit Facility, Credit Suisse & USD & 1,262 & $\mathrm{LBOR}+7.90 \%$ & PDVSA 2016 Financial Statements \\
\hline \begin{tabular}{|l|} 
PDVSA Petróleo, S.A. \& Subsidiaries Total Debt \\
\end{tabular} & & 1,263 & & \\
\hline Petrosanfelix, S.A. - $8.370 \%$ Guaranteed Bonds due 12/31/22 & USD & 1 & $8.22 \%-8.37 \%$ & PDVSA 2016 Financial Statements \\
\hline Petrowarao, S.A. - \$420m Credit Facility, Perenco Holdings & USD & 9 & LIBOR $+4.50 \%$ & PDVSA 2016 Financial Statements \\
\hline Petrocedeño, S.A. - \$60m Credit Facility, Novo Banco & USD & 20 & $1.320 \%$ & PDVSA 2016 Financial Statements \\
\hline Petrozamora, S.A. - S1,000m Prepayment Facility, GPB Energy Services & USD & 143 & LBBOR $+6.9 \%$ & PDVSA 2016 Financial Statements \\
\hline Petrolera Sinovensa, S.A. - \$4,015m Credit Facility, CDBC & USD & 1,256 & $\mathrm{LBOR}+5.8 \%$ & PDVSA 2016 Financial Statements \\
\hline Petroboscán, S.A. - \$2,000m Credit Facility, Chevron & USD & 626 & $\mathrm{LBOR}+4.5 \%$ & PDVSA 2016 Financial Statements \\
\hline Petroquiriquire, S.A. - $\$ 1,200 \mathrm{~m}$ Credit Facility, Repsol & USD & 909 & & PDVSA 2016 Financial Debt Balance \\
\hline Petrodelta, S.A. - \$20m Unsecured Loan, CT Energia Holding Ldd & VEF & & $12.000 \%$ & PDVSA 2016 Financial Statements \\
\hline \begin{tabular}{|l} 
Corp. Venezolana del Petróleo, S.A. \& Subsidiaries Total Debt \\
\end{tabular} & & 2,970 & & \\
\hline Panavenflot Corp - $¥ 20,000 \mathrm{~m}$ Credit Facility, JBIC & YEN & 99 & CIRR 1.77\% floor $+3.12 \%$ & PDVSA 2016 Financial Statements \\
\hline & 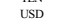 & 19 & $7.000 \%$ & PDVSA 2016 Financial Statements \\
\hline Capital Leases of PDVMarina & USD & 121 & & PDVSA 2016 Financial Statements \\
\hline \begin{tabular}{|l} 
PDV Marina, S.A. \& Subsidiaries Total Debt \\
\end{tabular} & & 239 & & \\
\hline Capital Leases of Refineria Isla Curazao & USD & 68 & & PDVSA 2016 Financial Statements \\
\hline $\begin{array}{l}\text { Refineria lsal (Curzaza), S.A. \& Subsidiaries Total Debt } \\
\text { Total Subsidiary Level Det. }\end{array}$ & & 68 & & \\
\hline
\end{tabular}

\begin{tabular}{|c|c|c|c|c|}
\hline Liabilities & Currency & $\begin{array}{l}\text { Outstanding } \\
\text { USS million }\end{array}$ & $\begin{array}{c}\text { Interest } \\
\text { Rate }\end{array}$ & $\begin{array}{l}\text { Information } \\
\text { Source }\end{array}$ \\
\hline \begin{tabular}{|c|c|c|c|c|} 
Total Subsidiary Level Debt \\
\end{tabular} & & 8,867 & & \\
\hline$\$ 1,226 \mathrm{~m}$ Secured Loan, JBIC & usD & 1,226 & $\mathrm{LIBOR}+0.50 \%-6.50 \%$ & PDVSA 2016 Financial Statements \\
\hline$\$ 950 \mathrm{~m}$ Secured Loan, JBIC & UsD & 950 & LIBOR $+1.50 \%-8.75 \%$ & PDVSA 2016 Financial Statements \\
\hline $8.500 \%$ Senior Secured Notes due 10/27/20 & UsD & 2,526 & $8.500 \%$ & PDVSA 2016 Financial Statements \\
\hline Capital Leases of Petroleos de Venezuela SA & USD & & & PDVSA 2016 Financial Statements \\
\hline Petróleos de Venezuela, S.A. Secured Liabilities & & 4,703 & & \\
\hline$\$ 15 \mathrm{~m}$ Investment Certificate, Banco de Venezuela & VEF & 15 & $14.000 \%$ & PDVSA 2016 Financial Statements \\
\hline$\$ 270 \mathrm{~m}$ Investment Certificate, BANDES & USD & 270 & $6.000 \%$ & PDVSA 2016 Financial Statements \\
\hline$\$ 3 m$ Investment Certificate, Banco de Venezuela & VEF & 3 & $8.000 \%$ & PDVSA 2016 Financial Statements \\
\hline$\$ 7 \mathrm{~m}$ Investment Certificate, Banco del Tesoro, Banco Universal & VEF & 7 & $8.00 \%$ & PDVSA 2016 Financial Statements \\
\hline$\$ 3 m$ Investment Certificate, FOGADE & VEF & 3 & $9.500 \%$ & PDVSA 2016 Financial Statements \\
\hline$\$ 92 \mathrm{~m}$ Investment Certificate, BANDES & USD & 92 & $6.000 \%$ & PDVSA 2016 Financial Statements \\
\hline 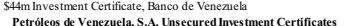 & VEF & $\frac{44}{434}$ & $18.000 \%$ & PDVSA 2016 Financial Statements \\
\hline$\$ 257 \mathrm{mCredit}$ Note, General Electric & usD & ${ }_{231}^{434}$ & $6.500 \%$ & PDVSA 2016 Financial Statements \\
\hline$\$ 100 \mathrm{~m}$ Credit Note, CPVEN & USD & 100 & $6.500 \%$ & PDVSA 2016 Exchange Offering Circular \\
\hline$\$ 100 \mathrm{~m}$ Credit Note, Petroalianza & USD & 100 & $6.500 \%$ & PDVSA 2016 Exchange Offering Circulat \\
\hline$\$ 118 \mathrm{~m}$ Credit Note, Maritime Contractors & USD & 118 & $6.500 \%$ & PDVSA 2016 Exchange Offering Circular \\
\hline$\$ 120 \mathrm{~m}$ Credit Note, Weatherford & USD & 120 & $6.500 \%$ & PDVSA 2016 Exchange Offering Circular \\
\hline$\$ 200 \mathrm{~m}$ Credit Note, Halliburton & USD & 200 & $6.500 \%$ & PDVSA 2016 Exchange Offering Circular \\
\hline$\$ 66 m$ Credit Note, ESVENCA & USD & 66 & $6.500 \%$ & PDVSA 2016 Exchange Offering Circular \\
\hline \$27m Credit Note, PROAMSA & USD & 27 & $6.500 \%$ & PDVSA 2016 Exchange Offering Circular \\
\hline$\$ 190 \mathrm{~m}$ Credit Note, Elecnor & USD & 190 & $6.500 \%$ & PDVSA 2016 Exchange Offering Circular \\
\hline \$37m Credit Note, Servicios Picardi & USD & 37 & $6.500 \%$ & PDVSA 2016 Exchange Offering Circular \\
\hline \$409m Credit Notes, Other Suppliers & USD & 409 & $6.500 \%$ & PDVSA 2016 Financial Statements \\
\hline Petróleas de Venezuela, S.A. Unsecured Credit Notes & & 1,597 & & \\
\hline Bs 1,587m Credit Facility, Banco de Venezuela & VEF & 2 & $12.500 \%$ & PDVSA 2016 Financial Statements \\
\hline Bs $635 \mathrm{~m}$ Credit Facility, Banco del Tesoro & VEF & & $9.500 \%$ & PDVSA 2016 Financial Statements \\
\hline$\$ 500$ m Credit Facility, CDBC & USD & 177 & $\mathrm{LIBOR}+4.55 \%$ & PDVSA 2016 Financial Statements \\
\hline$\$ 638$ m Credit Facility, BNDES & USD & 241 & LIBOR $+2.20 \%$ & PDVSA 2016 Financial Statements \\
\hline$\$ 300 \mathrm{~m}$ Credit Facility, Banco San Juan & USD & 117 & $6.25 \%-7.5 \%$ & PDVSA 2016 Financial Statements \\
\hline$\$ 230 \mathrm{~m}$ Credit Facility, General Electric & USD & 37 & $7.500 \%$ & PDVSA 2016 Financial Statements \\
\hline Petróleos de Venezuela, S.A. Unsecured Credit Facilities & & 575 & & \\
\hline$\$ 50 \mathrm{~m}$ Unsec. Loan, BANDES & USD & 50 & $\mathrm{LBOR}+5.00 \%$ & PDVSA 2016 Financial Debt Balance \\
\hline$\$ 62 \mathrm{~m}$ Unsec. Loan, Deutsche Bank & USD & 62 & LBBOR $+7.20 \%$ & PDVSA 2016 Financial Statements \\
\hline \$1m Unsec. Loan, Banco de Venezuela(1) & VEF & 1 & $12.500 \%$ & PDVSA 2016 Financial Statements \\
\hline \$1m Unsec. Loan, Banco de Venezuela(2) & VEF & 1 & $12.500 \%$ & PDVSA 2016 Financial Statements \\
\hline \$7m Unsec. Loan, Banco de Venezuela & VEF & 7 & $12.000 \%$ & PDVSA 2016 Financial Statements \\
\hline \$4m Unsec. Loan, Banco de Venezuela(1) & VEF & 4 & $12.500 \%$ & PDVSA 2016 Financial Statements \\
\hline \$3m Unsec. Loan, Banco de Venezuela & VEF & 3 & $12.500 \%$ & PDVSA 2016 Financial Statements \\
\hline \$1m Unsec. Loan, National Public Banks & VEF & 1 & $12.000 \%$ & PDVSA 2016 Financial Statements \\
\hline \$4m Unsec. Loan, Banco de Venezuela(2) & VEF & 4 & $12.500 \%$ & PDVSA 2016 Financial Statements \\
\hline \$5m Unsec. Loan, Banco de Venezuela & VEF & 5 & $12.000 \%$ & PDVSA 2016 Financial Statements \\
\hline \$4m Unsec. Loan, Banco de Venezuela(3) & VEF & 4 & $12.500 \%$ & PDVSA 2016 Financial Statements \\
\hline$\$ 29 \mathrm{~m}$ Unsec. Loan, National Public Banks & VEF & 29 & $14.000 \%$ & PDVSA 2016 Financial Statements \\
\hline \$10m Unsec. Loan, BANDES & USD & 10 & & PDVSA 2016 Financial Debt Balance \\
\hline$\$ 600 \mathrm{~m}$ Unsec. Loan, CDBC & uSD & 600 & $\mathrm{LBOR}+6.25 \%$ & PDVSA 2016 Financial Statements \\
\hline Petróleos de Venezuela, S.A. Unsecured Loans & & 781 & & \\
\hline $9.100 \%$ Unsecured Bonds due $07 / 14 / 17$ & VEF & 2 & $9.100 \%$ & PDVSA 2016 Financial Statements \\
\hline $5.375 \%$ Unsecured Bonds due $04 / 12 / 27$ & USD & 3,000 & $5.375 \%$ & PDVSA 2016 Financial Statements \\
\hline $5.500 \%$ Unsecured Bonds due $04 / 12 / 37$ & USD & 1,500 & $5.500 \%$ & PDVSA 2016 Financial Statements \\
\hline $9.000 \%$ Unsecured Bonds due 11/17/21 & USD & 2,394 & $9.000 \%$ & PDVSA 2016 Financial Statements \\
\hline $6.000 \%$ Unsecured Bonds due $10 / 28 / 22$ & USD & 3,000 & $6.000 \%$ & PDVSA 2016 Financial Statements \\
\hline $12.750 \%$ Unsecured Bonds due $02 / 17 / 22$ & USD & 3,000 & $12.750 \%$ & PDVSA 2016 Financial Statements \\
\hline $6.000 \%$ Unsecured Bonds due $05 / 16 / 24$ & USD & 5,000 & $6.000 \%$ & PDVSA 2016 Financial Statements \\
\hline $6.000 \%$ Unsecured Bonds due $11 / 15 / 26$ & USD & 4,500 & $6.000 \%$ & PDVSA 2016 Financial Statements \\
\hline $9.756 \%$ Unsecured Bonds due $05 / 17 / 35$ & USD & 3,000 & $9.750 \%$ & PDVSA 2016 Financial Statements \\
\hline Petróleos de Venezuela, S.A. Unsecured Bonds & & 25,396 & & \\
\hline Petróleos de Venezuela, S.A. Unsecured Debt & & 28,783 & & \\
\hline 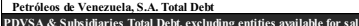 & & 33,486 & & \\
\hline
\end{tabular}




\begin{tabular}{|c|c|c|c|c|}
\hline Liabilities & Currency & $\begin{array}{c}\text { Outstanding } \\
\text { USS million } \\
\end{array}$ & $\begin{array}{c}\text { Interest } \\
\text { Rate }\end{array}$ & $\begin{array}{c}\text { Information } \\
\text { Source }\end{array}$ \\
\hline PDVSA \& Subsidiaries Total Debt, excluding entities available for sale & & 42,353 & & \\
\hline Trocana World Inc - \$28m Secured Loan, BANDES & USD & 28 & $\mathrm{LBOR}+1.00 \%$ & PDVSA 2016 Financial Statements \\
\hline Tovase Development Corp - \$31m Secured Loan, BANDES & USD & 31 & $\mathrm{LBOR}+1.00 \%$ & PDVSA 2016 Financial Statements \\
\hline Fluvialba - $57 \mathrm{~m}$ Unsecured Loan, Banco Credicorp & ARS & 7 & $26.000 \%$ & PDVSA 2016 Financial Statements \\
\hline PDV Caribe - \$24m Unsecured Loan, BANDES & USD & 16 & $6.000 \%$ & PDVSA 2016 Financial Statements \\
\hline $\begin{array}{l}\text { Capital Leases of PDVSA América } \\
\text {. }\end{array}$ & & 1 & & PDVSA 2016 Financial Statements \\
\hline \begin{tabular}{|l|l} 
PDVSA América, S.A. \& Subsidiaries, Total Debt \\
\end{tabular} & & 83 & & \\
\hline El36m Credit Facility, Novo Banco & EUR & 10 & EURIBOR $+3.8 \%$ & PDVSA 2016 Financial Statements \\
\hline \begin{tabular}{|l|l} 
Total PDVSA Naval S.A. \& subsidiaries \\
\end{tabular} & & 10 & & \\
\hline Entities available for sale, Total Debt & & 93 & & \\
\hline PDVSA \& Subsidiaries Total Debt, including entities available for sale & & 42,446 & & \\
\hline$\$ 8,000 \mathrm{~m}$ Promissory Notes, BCV & $\mathrm{NA}$ & 8,000 & $3.500 \%$ & PDVSA 2016 Financial Statements \\
\hline$\$ 391 \mathrm{~m}$ Accounts Payable, Republic of Venezuela & $\mathrm{NA}$ & 391 & & PDVSA 2016 Financial Statements \\
\hline \$3,723m Promissory Notes, PDVSA Pension Funds & $\mathrm{NA}$ & 3,723 & $9.500 \%$ & PDVSA 2016 Financial Statements \\
\hline$\$ 3,843 \mathrm{~m}$ Accounts Payable, Other related parties & $\mathrm{NA}$ & 3,843 & & PDVSA 2016 Financial Statements \\
\hline Accounts Payable to Related Entities & & 15,957 & & \\
\hline$\$ 1,500 \mathrm{~m}$ Sec. Advance received from customers, Rosneft & USD & 1,500 & & PDVSA 2016 Financial Statements \\
\hline$\$ 500 \mathrm{~m}$ Sec. Advance received from customers, Rosneft & USD & 500 & & PDVSA 2016 Financial Statements \\
\hline$\$ 4,000 \mathrm{~m}$ Unsec. Advance received from customers, Rosneft & USD & 4,362 & $\mathrm{LBOR}+4.00 \%$ & PDVSA 2016 Financial Statements \\
\hline $\begin{array}{l}\$ 500 \mathrm{~m} \text { Unsec. Advance received from customers, Rosneft } \\
\text { Advances received from cus tomers. Rosneft }\end{array}$ & USD & 500 & & PDVSA 2016 Financial Statements \\
\hline $\begin{array}{l}\text { Advances received from customers, Ros neft } \\
\$ 2,007 \mathrm{~m} \text { Dividends payable to non-controlling interests }\end{array}$ & & 6,862 & & \\
\hline$\$ 2,007 \mathrm{~m}$ Dividends payable to non-controlling interests & $\mathrm{NA}$ & 2,007 & & PDVSA 2016 Financial Statements \\
\hline$\$ 2,662 \mathrm{~m}$ Notes \& Accrued Payables to contractors & $\mathrm{NA}$ & 2,662 & & PDVSA 2016 Financial Statements \\
\hline$\$ 397 \mathrm{~m}$ Interest payable & $\mathrm{NA}$ & 397 & & PDVSA 2016 Exchange Offering Circular \\
\hline PDVSA Pension \& Other benefits (net of CITGO Petroleum) & $\mathrm{NA}$ & 3,092 & & PDVSA 2016 Financial Statements \\
\hline \begin{tabular}{|l|} 
PDVSA Accrued Payables and Other Liabilities \\
\end{tabular} & & 30,977 & & \\
\hline CITGO Pension \& Other benefits & USD & 720 & & CITGO Petroleum 2016 Financial Statement \\
\hline CrTGO Other Liabilities & & $\frac{1200}{720}$ & & \\
\hline PDVSA \& Subsidiaries Other Liabilitites & & 31,697 & & \\
\hline PDVSA Total Debt \& Other Liabilities & & 74,143 & & \\
\hline
\end{tabular}




\section{Appendix 5: PDVSA's Debt Collateral and Guarantees}

Table 2: PDVSA's Financial Debt with Collateral Packages and/or Group

\begin{tabular}{|c|c|c|c|c|c|}
\hline & & Guars & antees $^{265}$ & & \\
\hline Issuer & Obligation & Guantor & Guaranten Note & soured? & Collatera, if known \\
\hline & $\begin{array}{l}\text { S1,20m Saured Lon, JBIC } \\
\text { S950m Saured Loan, JBIC }\end{array}$ & $\begin{array}{l}\text { NA } \\
\text { NA }\end{array}$ & $\frac{N A}{N A}$ & $\frac{p}{r}$ & NA \\
\hline & 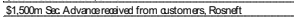 & NA & $\mathrm{NA}$ & r & $49.9 \%$ of the copita sook of a TGO Holding Inc \\
\hline & S5500m Sec Advanereacived from astomess, Rosneft & $\mathrm{NA}$ & $\mathrm{NA}$ & $r$ & 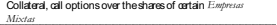 \\
\hline & $8.500 \%$ Snior Sacured Notes due 1027120 & PDVSA Patróleo SA. & Sanior searred Obligation of the Guarntor & $\checkmark$ & $\begin{array}{l}\text { First-prionitylilen on 50.1\% of the cepita stod of CITGO } \\
\text { Holding. Inc }\end{array}$ \\
\hline & $\frac{5.375 \% \text { Unseared Bonds due } 04112.27}{5550}$ & PDVSA PAtrolleo SA. & Unsearred, senior obligations of the & $x$ & \\
\hline $\begin{array}{l}\text { Petroleos de } \\
\text { venezudaSA. }\end{array}$ & 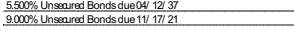 & $\begin{array}{l}\text { PDVSA Parbleo SA. } \\
\text { PDVSA Petroleo SA. }\end{array}$ & $\begin{array}{l}\text { Unseured, senior obligations of the } \\
\text { Unsearred, senior bobligations of the }\end{array}$ & $\begin{array}{l}x \\
x \\
\end{array}$ & \\
\hline & $6.000 \%$ Unseared Bonds due $1028 \mathrm{2} 22$ & PDVSA Petrolleo SA. & $\begin{array}{l}\text { Unseared, senior obligations of the } \\
\text { Guarantor }\end{array}$ & $\times$ & \\
\hline & $12750 \%$ Unsearred Bonds due $02217 / 22$ & PDVSA Patroleo SA. & Unsearred, senior obligations of the & $x$ & \\
\hline & $6.000 \%$ Unseared Bonds due 05/16/24 & PDVSA Pedróleo SA. & $\begin{array}{l}\text { Unsearred, senior obligations of the } \\
\text { Gurator }\end{array}$ & $\times$ & \\
\hline & $6.000 \%$ Unsearned Bonds due 11/15/ 26 & PDVSA Patróleo SA. & $\begin{array}{l}\text { Unsearred, senior obligations of the } \\
\text { Gurantor }\end{array}$ & * & \\
\hline & $9.750 \%$ Unseared Bonds due $05 / 17 / 35$ & PDVSA Péróleo SA. & $\begin{array}{c}\text { Unsearred, senior obligations of the } \\
\text { Gurantor }\end{array}$ & $\times$ & \\
\hline & S650m Sanior Seared Tem Lon B & $\begin{array}{l}\text { a TGO Patroleum } \\
\text { Corp''smateria } \\
\text { subsidiaries }\end{array}$ & Senior obligations of the Guarntors & r & 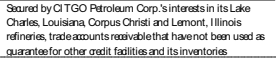 \\
\hline & s900m Seared Revolving Ceedit Faility & $\begin{array}{l}\text { G TGO Patroleum } \\
\text { Corp''smateriad } \\
\text { subsidiaies }\end{array}$ & Senior obligations of the Guarntors & $r$ & 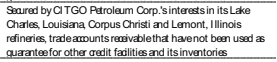 \\
\hline & S450m Searred A R Rasility & NA & NA & $\mathrm{s}$ & 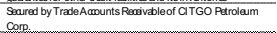 \\
\hline CITGO & $6.250 \%$ Snior Seared Notes due $0815 / 22$ & $\begin{array}{l}\text { ATGO Patroleum } \\
\text { Corp.'smateria } \\
\text { subsidiaries }\end{array}$ & Snior obligations of the Gurantors & $r$ & 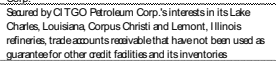 \\
\hline $\begin{array}{l}\text { Pefrolum } \\
\text { Corp. }\end{array}$ & $4.800 \%$ Industria tax exempt bond due $065101 / 25$ & NA & NA & v & 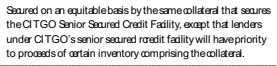 \\
\hline & $8.000 \%$ Industria tax exempt bond due 04010128 & NA & NA & & 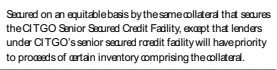 \\
\hline & $8.000 \%$ Industria tax exempt bond due 0660132 & NA & $\mathrm{NA}$ & $\checkmark$ & 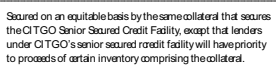 \\
\hline $\begin{array}{c}\text { CITGO } \\
\text { HoldingInc }\end{array}$ & \$1,300m Snior Soured Term Lon B & 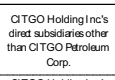 & $\mathrm{NA}$ & & 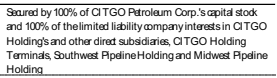 \\
\hline Holding Inc & $10.750 \%$ Snior Sacred Notes due 0215120 & 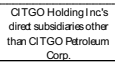 & $\mathrm{NA}$ & $r$ & 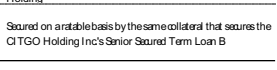 \\
\hline $\begin{array}{c}\text { PDVSA } \\
\text { Petróleo SA. } \\
\end{array}$ & $\$ 2,206 \mathrm{~m}$ Credit Faility, Credit Misse & $\begin{array}{l}\text { Patróleos deV Veneveda } \\
\text { SA. }\end{array}$ & 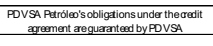 & * & \\
\hline 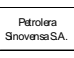 & Patrolara Snovensa SA. S4,015m Credit Failty, CDBC & $\begin{array}{l}\text { Patróleos de Venevuda } \\
\text { SA. }\end{array}$ & 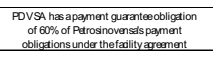 & $\times$ & \\
\hline $\begin{array}{l}\text { Patrobosén } \\
\text { SA. }\end{array}$ & Petrobosśn, SA. - \$2,000m Credit Faility, Cherron & $\begin{array}{l}\text { Patroleos deV Venevuda } \\
\text { SA. }\end{array}$ & 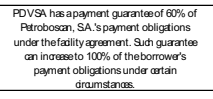 & * & \\
\hline $\begin{array}{c}\text { PDVMaina } \\
\text { SA. }\end{array}$ & S111m Searred Lon, Deutshe Bank & $\mathrm{NA}$ & $\mathrm{NA}$ & 2 & $\mathrm{NA}$ \\
\hline $\begin{array}{l}\text { TroconaWorld } \\
\text { Inc- Soured } \\
\text { Loan }\end{array}$ & Trocena World Inc- $528 \mathrm{~m}$ Soured Lon, BANDES & NA & NA & r & $\mathrm{NA}$ \\
\hline $\begin{array}{c}\text { Tovese } \\
\text { Derdopment } \\
\text { Corp. }\end{array}$ & Tovere Deadopment Corp - S31m Searred Loan, BANDES & NA & NA & $\checkmark$ & $\mathrm{NA}$ \\
\hline
\end{tabular}

265. Source: Bloomberg; PDVSA 2016 Debt Balance Report; PDVSA 2016 Exchange Offering Circular 


\section{Appendix 6: Doing Business, Resolving Insolvency Rankings}

Figure 10: Resolving Insolvency Ranking

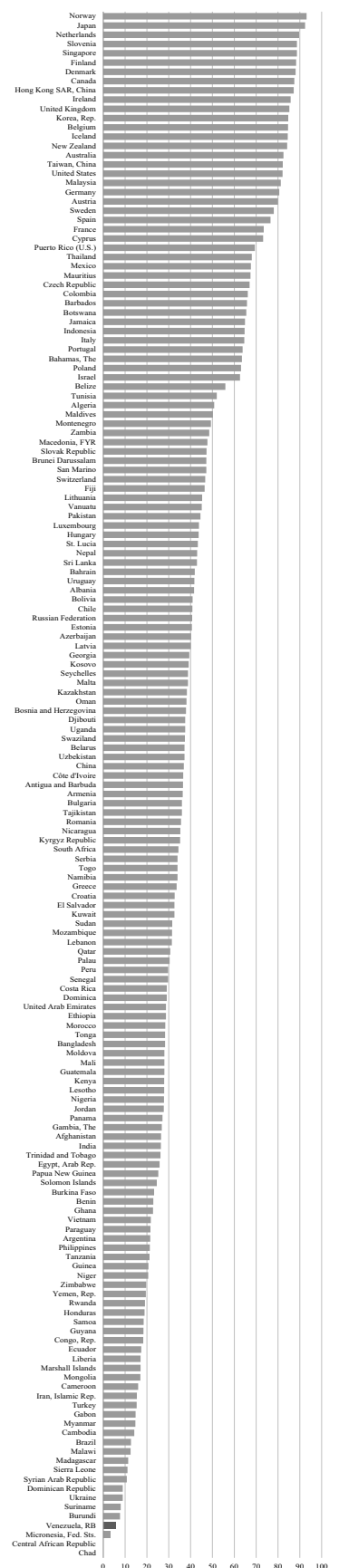

Figure 11: Strength of Insolvency Framework $($ Max score $=16)$

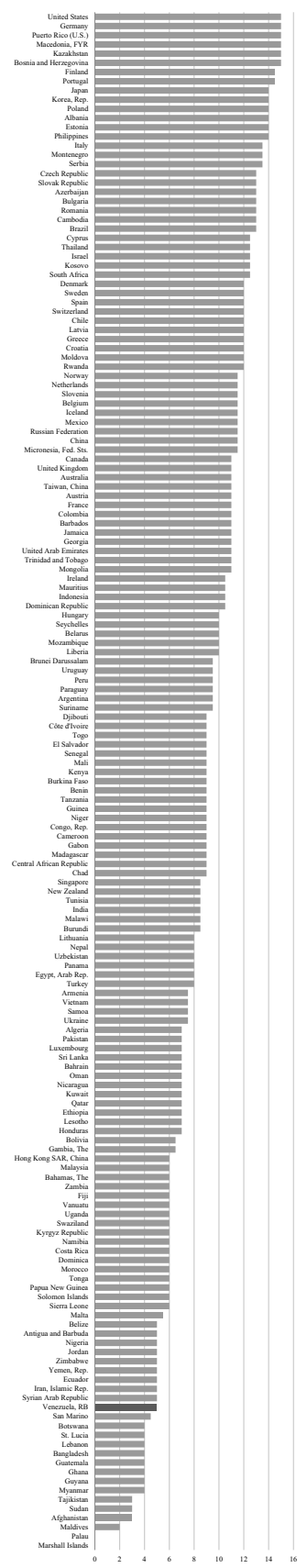


Figure 13: Recovery Rate (Secured Creditors)

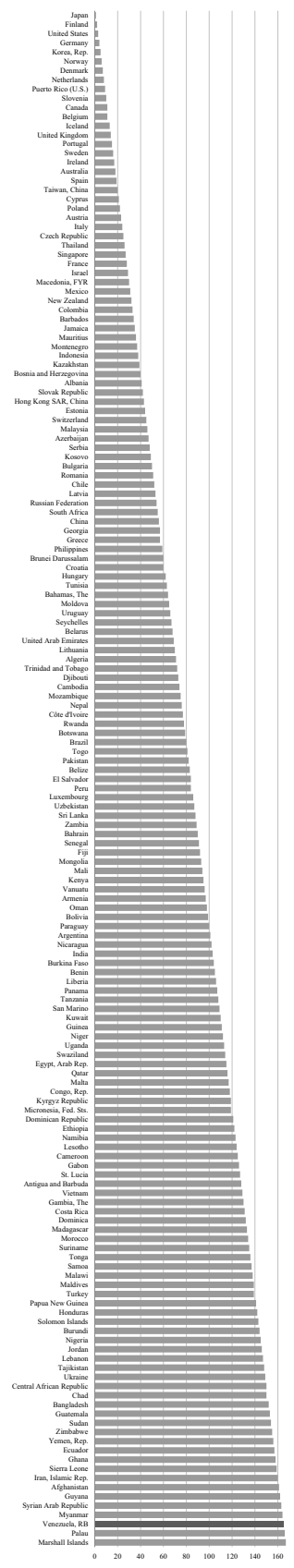

Figure 12: Length of Procedure (Time, in years)

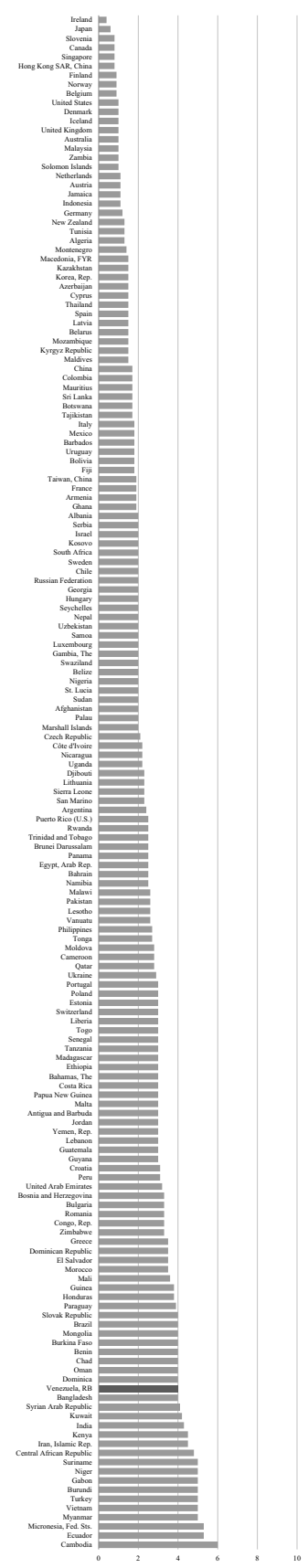

Source: World Bank, Resolving Insolvency 